University of Windsor

Scholarship at UWindsor

\title{
Biological removal of hydrogen sulfide from refinery wastewater and conversion to elemental sulfur.
}

\author{
Paul F. Henshaw \\ University of Windsor
}

Follow this and additional works at: https://scholar.uwindsor.ca/etd

\section{Recommended Citation}

Henshaw, Paul F., "Biological removal of hydrogen sulfide from refinery wastewater and conversion to elemental sulfur." (1990). Electronic Theses and Dissertations. 1304.

https://scholar.uwindsor.ca/etd/1304

This online database contains the full-text of PhD dissertations and Masters' theses of University of Windsor students from 1954 forward. These documents are made available for personal study and research purposes only, in accordance with the Canadian Copyright Act and the Creative Commons license-CC BY-NC-ND (Attribution, Non-Commercial, No Derivative Works). Under this license, works must always be attributed to the copyright holder (original author), cannot be used for any commercial purposes, and may not be altered. Any other use would require the permission of the copyright holder. Students may inquire about withdrawing their dissertation and/or thesis from this database. For additional inquiries, please contact the repository administrator via email (scholarship@uwindsor.ca) or by telephone at 519-253-3000ext. 3208. 


\section{NOTICE}

The quality of this microform is heavily dependent upon the quality of the original thesis submitted for microtilming. Every eflort has been made to ensure the highest quality of reproduction possible.

If pages are missing, contact the university which granted the degree.

Some pages may have indistinct print especially if the original pages were typed with a poor typewriter ribbon or if the university sent us an inferior photocopy.

Reproduction ir. full or in part of this microtorm is governed by the Canadian Copyright ACi, R.S.C. 1970, C. C-30, and subsequent amendments.

\section{AVIS}

La qualité de celte microforme dépend grandement de la qualité de la thèse soumise au microfilmage. Nous avons tout fait pour assurer une qualité supérieure de reproduc. tion.

S'il manque des pages, veuillez communiquer avec l'université qui a conléré le grade.

La qualité d'impression de certaines pages peut hissẹr ì désirer, surtout si les pages originales ont élé dactylogıa phiées à l'aide d'un ruban usé ou si l'université nous a liıll parvenir une photocopie de qualité intérieure.

La reproduction, méme partielle, de celte microlorme est soumise à la Loi canadienne sur le droil d'auleur. SHC 1970 , c. C.30, et ses amendements subséquents. 


\title{
Biological Rewoval of Hyirogen sulfide from Refinery wastewater and Conversion to Elemental sulfur
}

\author{
A Thesis Submitted to the \\ Faculty of Graduate studies and Research \\ Through the Department of Civil \& Environmental Engineering \\ in Partial Fulfillment of the Requirements for the \\ Degree of Master of Applied Science \\ at the University of Windsor \\ by \\ Paul F. Henshaw
}

Windsor, ontar 1o, Canada

September 1990 
Canadian Theses Service Service des thèses canadiennes

The author has granted an irrevocable nonexclusive licence allowing the National Library of Canada to reproduce, loan, distribute or sell copies of his/her thesis by any means and in any form or format, making this thesis available to interested persons.

The author retains ownership of the copyright in his/her thesis. Neither the thesis nor substantial extracts from it may be printed or otherwise reproduced without his/her permission.
L'auteur a accordé une licence irrévocable et non exclusive permettant à la Bibliothèque nationale du Canada de reproduire, prêter. distribuer ou vendre des copies de sa thèse de quelque manière et sous quelque forme que ce soit pour mettre des exemplaires de cette thèse à la disposition des personnes intéressées.

L'auteur conserve la proprièté du droit d'auteur qui protège sa thèse. Ni la thèse ni des extraits substantiels de celle-ci ne doivent être imprimés ou autrement reproduits sans son autorisation.

\section{Canadä}


- Paul F. Henshaw 1990 


\section{ABSTRAT}

The use of the green sulfur bacterium Chlorobiun limicola forma specialis thiosulfatophilum in a bioreactor is proposed as a means of removing hydrogen sulflde from process water and producing elemental sulfur. For petroleum refineries, this is an alternative to sour water stripping followed by the claus process.

The analytical methods that were found to work without interference from other sulfux specles were: methylene blue for sulfide, cyanide for elemental sulfur and turbidimetric for sulfate.

Elemental Sulfur was successfully produced from sodium sulfide in a batch reactor by $C$. thiosulfatophilum. From 1 to $90 \%$ of the sulfide consumed was recovered as elemental sulfur. There was a mild correlation between the initial $\mathrm{pH}$ and the percent recovery of sulfur.

The speciflc gronth rate of $C$. thlosulfatophilum was found to be higher than that found in prevlous work. The Haldane equation for substrate inhibition was used to calculate the maximum speciflc growth rate as $0.45 \mathrm{~h}^{-2}$. The maximum tolerable level of sulfide was found to be $300 \mathrm{mg} / \mathrm{L}$. The highest rate of substrate utillzation was found to be $17.3 \mathrm{mg} / \mathrm{L} \cdot \mathrm{h}$. 


\section{ACKNOW FDCERENTS}

The author wishes to thank Professors J.K. Bewtra and Nihar Biswas for their availability, advice and encouragement throughout the research and writing of this thesis.

I am thankful to Professor M. Franklin for his advice and the use of his laboratory equipment. I am also thankful to my fellow graduate students, especially James Nicell, for sharing their knowledge.

Finally, I am thankful to my wife cheryl for her encouragement, organization and proofreading of this thesis.

This research was financed by grants from the Natural Sclence and Engineering Research Council and Imperial 011 of Canada Limited. 


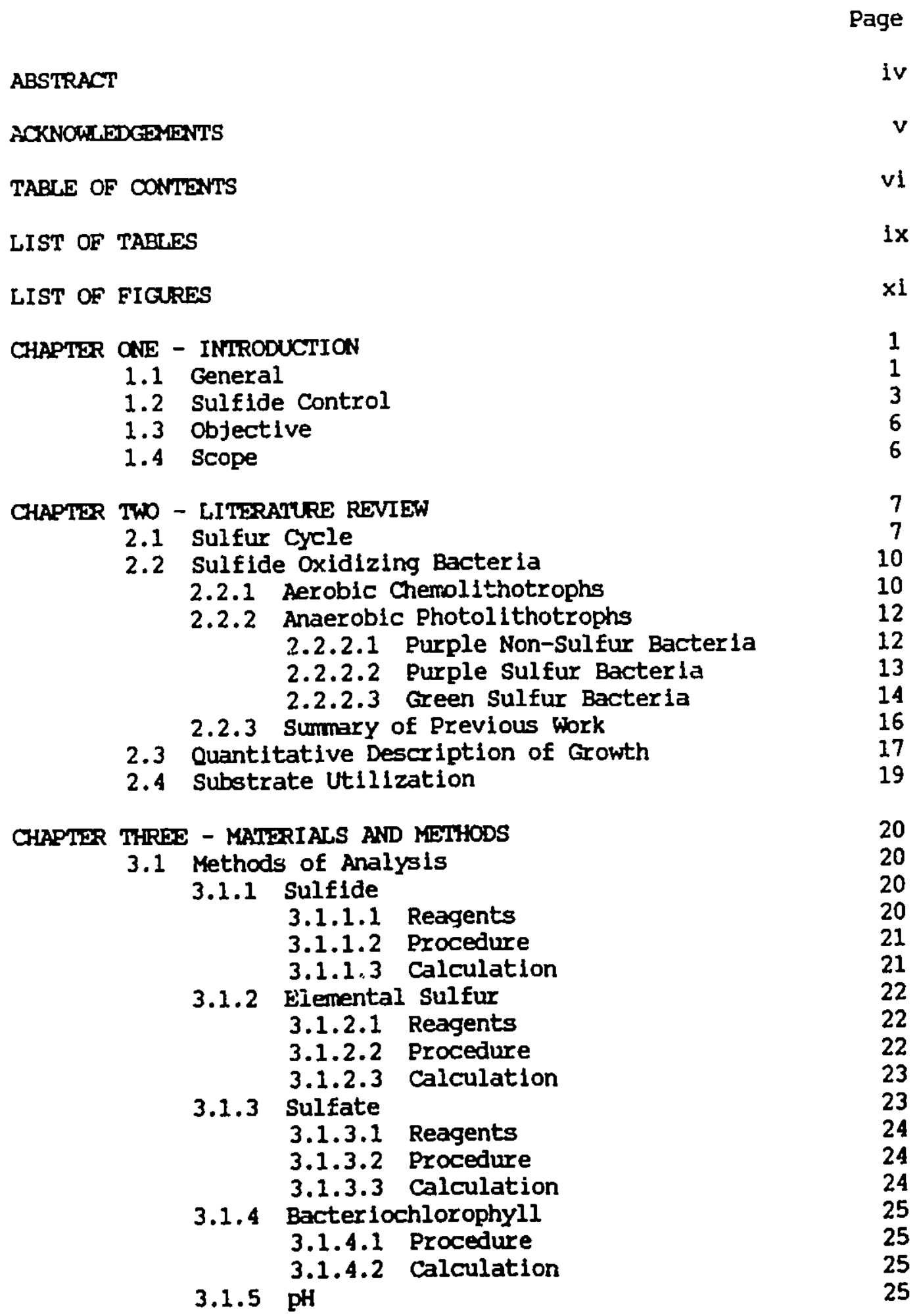


3.2 Apparatus 26

3.2.1 Bacterla 26

3.2 .2 Reactor 26

3.2 .3 Medlum 26

3.2.3.1 Cuiture Tubes 29

3.2.3.2 One Litre Reactor 29

3.2.3.3 Flfteen Litre Reactor 29

3.3 Experimental Protocol 30

3.3.1 Innocuiation and Incubation 30

3.3.2 Batch Reactor Tests 31

3.3.3 Semi-Batch Reactor Test 33

3.3.4 Calculations 33

CHAPTER FOUR - RESULTS AND DISCUSSION 36

4.1 Batch Reactor 'rests 36

4.1.1 Data 36

4.1.2 Growth of Bacteria 51

4.1.3 Sulfur Balance and Recovery 53

4.2 Semi-Batch Reactor Tests 63

4.2.1 Data 63

4.2.2 Growth of Bacteria 66

4.2.3 Sulfur Balance and Recovery 66

4.3 Discussion 66

4.3.1 Growth of Bacteria 66

4.3.2 Sulfur Recovery 76

4.3.3 Sulfide Utilization 76

CHAPTER FIVE - CONCLUSICNS AND RDOOMENDATIONS 83

5.1 Conclusions 83

5.2 Recommendations $\quad 84$

$\begin{array}{lr}\text { REFERENCES } & 85\end{array}$

AEPENDIX A - DEVELOPMENT OF METHODS OF ANALYSIS 90

A.1 General 90

A.1.1 Reagents 90

A.1.2 Apparatus 91

A.1.3 Statistical Analysis 91

A.2 Sulfide 92

A.2.1 Iodometric Method 92

A.2.2 Potentiometric Method 98

A.2.3 Methylene Blue Method 105

A.3 Elemental Sulfur 111

A.3.1 Ethanol Method 111

A.3.2 Cyanide Method 122

A.4 Sulfate 125

A.5 Bacteriochlorophyll $\quad 135$

APPENDIX B - MEASUREPSENT OF REACTOR ILIUMINANCE 138

B.1 Materials and Methods 138

B.2 Results 139 
APPENDIX C - CALCULATION GF THE AMOUNT OF AVAILABCE

141

C.1 Carbon Dioxide Inputs

141

c. 2 Sulfide That Can Be Utilised

141

VITA AUCTORIS

142 
Table

Page

3.1 Initial Values of $\mathrm{pH}$ and Sulfide Concentration

4.1 Determination of Specific Growth Rate in Batch Reactor Runs

4.2 Sulfux Recovery for Batch Reactor Runs

4.3 Determination of Speciflc Growth Rate in Semi-Batch Reactor Injections

4.4 S'ulfur Recovery for Semi-Batch Reactor Injections

A.1 Quantities of Reagents Used to Investigate Iodometric Method for Sulfide Analysis

A.2 Results of Trials of Iodometric Method for Sulfide Analysis

A. 3 Reagents and Procedures Used to Investigate Potentiometric Method for Sulfide Analysis

A.4 Results of Trials of Potentiometric Method for Sulfide Analysis

A.5 Comparison of Reagents in Methylene Blue Methods of Sulfide Analysis

A. 6 Calibration of Truper's Methylene Blue Method of Sulfide Analysis Without Added Sulfur Compounds

A.7 Callbration of Truper's Methylene Blue Method of Sulfide Analysis with and without Added Sulfur Compounds

A.8 Results of Second Test of Ethanol Method of Elemental Sulfur Analysis with Added Sulfur Compounds

A.9 Test of Acid Correction of Sulfide Interference on Ethanol Method of Elemental Sulfur Analysis

A.10 Calibration of Cyanide Method of Elemental Sulfur Analysis With and Without Added Sulfur Compounds 
A.11 Effect of Concentrations of Sulfide and Elemental sulfur on Turbidimetric method of Sulfate Analys is

A.12 Calibration of Turbidimetric Method of Sulfate Analysis with and without Added Sulfur Compounds 


\section{LIST OR FIGURES}

Figure

1.1 The Sour water Stripping Process 5

2.1 Bacterial Interactions in a Sulfuretum 8

2.2 The Blomass Growth and Decay Curve 18

3.1 Photograph of the Bloreactor 27

4.1 Concentrations in Batch Reactor Run $1 \quad 37$

4.2 Reactor Environment for Batch Reactor Run $1 \quad 38$

4.3 Concentrations in Batch Reactor Run 2

4.4 Reactor Environment for Batch Reactor Run $2 \quad 40$

4.5 Concentrations in Batch Reactor Run $3 \quad 41$

4.6 Reactor Environment for Batch Reactor Run $3 \quad 42$

4.7 Concentrations in Batch Reactor Run 4

4.8 Reactor Environment for Batch Reactor Run 4

4.9 Concentrations in Batch Reactor Run 5

4.10 Reactor Environment for Batch Reactor Run $5 \quad 46$

4.11 Concentrations in Batch Reactor Run $6 \quad 47$

4.12 Reactor Environment for Batch Reactor Run $6 \quad 48$

4.13 Concentrations in Batch Reactor Run $7 \quad 49$

4.14 Reactor Environment for Batch Reactor Run $7 \quad 50$

4.15 Sulfur Balance for Batch Reactor Run 1

4.16 Sulfur Balance for Batch Reactor Control Run 1

4.17 Sulfur Balance for Batch Reactor Run 2

4.18 Sulfur Balance for Batch Reactor Run 3

4.19 Sulfur Balance for Batch Reactor Control Run 3

4.20 Sulfur Balance for Batch Reactor Run 5 
4.21 Sulfur Balance for Batch Reactor Run $6 \quad 60$

4.22 Sulfur Balance for Batch Reactor Run 7 61

4.23 Concentrations in Semi-Batch Reactor 64

4.24 Reactor Environment for Semi-Batch Reactor 65

4.25 Sulfur Balance for Semi-Batch Reactor 68

4.26 Specific Growth Rate of Bacteria versus Sulfide Concentration at Begining of Log-Growth Phase of Bacteria

4.27 Specific Growth Rate versus Initial pH in Batch and Sem-Batch Reactors

4.28 Plot for Calculation of True Cell yield 74

4.29 Dilute-out Curves in a Continuous-Flow Reactor without Recycle

4.30 Recovery of Sulfur versus Initial pH in Batch and Semi-Batch Reactors

4.31 Rate of Change in Sulfide Concentration versus Sulfide Concentration in Batch and Semi-Batch Reactors

4.32 Rate of Change in Sulfide Concentration versus Bchl Concentration in Batch and Sem:-Batch Reactors

4.33 Specific Utilization Rate of Sulfide versus Sulfide Concentration in Batch and Semi-Batch Reactors

Colour Development in Truper's Methylene Blue Method of Sulfide Analys is

A.2 Calibration of 'Truper's Methylene Blue Method of Sulfide Analysis Without Added Sulfur Compounds

A.3 Calibration of Truper's Methylene Blue Method of Sulfide Analysis with and without Added Sulfur Compounds

A. 4 Calibxation of Ethanol Method of Elemental Sulfur Analysis 
A.5 Test of Acld Correction of Sulfide Interference on Ethanol Method of Elemental Sulfur Analysis

A.6 Calibration of Bartlett's Cyanide Method of Elemental Sulfur Analysis

A.7 Calibration of Cyanide Method of Elemental Sulfur Analysis With and Without Added Sulfur Compounds

A. 8 Calibration of Turbidimetric Method of Sulfate Analysis Without Added Sulfur Compounds

A.9 Effects of Concentrations of Sulfide and Elemental Sulfur on Turbidimetric Method of Sulfate Analysis

A.10 Calibration of Turbidimetric Method of Sulfate Analysis with and without Added Sulfur Compounds

A.11 Calibrated Region for the Turbidimetric Method of Sulfate Analysis

A.12 Plot for Calculation of Uncertainty in Bchl Analysis

B.1 Sensor Locations for Measuring Reactor Illuminance 
GHPPIER ONB

INTRODCTION

\subsection{General}

It has been stated that, for Canadians, pollution is more often the cause of water problems than absolute scarcity of supply (SCC,1988). Inorganic compounds of sulfur are recelving increasing attention as water pollutants.

chemically, sulfide is the most reduced species of sulfur. In water, the sulfide ion $\left(\mathrm{S}^{2-}\right)$ remains in equilibrium with hydrosulfide fon (HS-) and hydrogen sulfide $\left(\mathrm{H}_{2} \mathrm{~S}\right)$. $\mathrm{H}_{2} \mathrm{~S}$ gas is highly toxic and malodorous (Cadena et al, 1988). For humans, its odour threshold is 0.13 ppm (MSDS, 1988) and it is fatal at concentrations higher than 13 ppm (Cadena et al.,1988). Sulfide has a high oxygen demand of $2 \mathrm{~mol} \mathrm{O}_{2} / \mathrm{mol} \mathrm{s}^{2-}$ and thus may cause significant depletion of oxygen in receiving waters (Kobayashi et al.,1983).

Sources of sulfide in the environment include domestic wastewater, anaerobic digestion of organic matter containing sulfur, heavy water plants (Gulens et al.,1982) and petroleum refinery processes. Anaerobic decomposition of wastewater releases $\mathrm{H}_{2} \mathrm{~S}(\mathrm{~g})$ which is oxidized to sulfuric acid at the crown of sanitary sewers, leading to the corrosion of concrete pipes and appurtenances (Gaudy et al.,1980). Anaerobic digestion of pulp mill effluent containing sulfite (Salkinoja et al.,1985) and liquifled water hyacinth waste (Kobayashi et al.,1983) are also sulfide sources.

Crude oll containing malodorous compounds ( $\mathrm{H}_{2} \mathrm{~S}$, mercaptans) is 
termed as sour crude (MOE,1987). In petroleum refinerles, sour gas contains $\mathrm{H}_{2} \mathrm{~S}$ whereas acld gas ccntains $\mathrm{H}_{2} \mathrm{~S}$ ond $\infty_{2}$. Fuel gases must be treated for $\mathrm{H}_{2} \mathrm{~S}$ removal in order to reduce the air pollution due to sulfur dioxide formed while burning the $\mathrm{H}_{2} \mathrm{~S}$ (Sitting,1978). Additional sovrces of sulfide within the refinery include hydrocrackers, thermal crackers, gas recovery units, hydro desulphurization units and steam (ethylene) crackers (MOE, 1987).

Sulfide discharge is regulated by the Federal Refinery Effluent Regulations and Guidelines. Currently its upper limit is $0.3 \mathrm{~kg} / 1000 \mathrm{~m}^{3}$ of oll refined/day for refinerles that commenced operations on or after Nov.1,1973. Refineries that were operating before that date are subject to the guidelines of $0.6 \mathrm{~kg} / 1000 \mathrm{~m}^{2}$ of oll refined/day (Geadah, 1987). The ontario refineries are further subject to effluent quality objectives. Sulfide is not covered by these guidelines, although the new MISA regulation promises to look at a wider range of contaminants (MOE,1988a). Indeed, the Effluent Monitoring Regulations for the Petroleum Refining Sector require sulfide testing of process effluent thrize weekly (MOE, 1988b).

Sulfate is the most oxidized form of sulfur. Although non-toxic, sulfates discharged in large quantities to surface waters can lead to excess mineralization (Maree et al.,1985). The U.S. Environmental Protection Agency (USEPA, 1990) set $250 \mathrm{mg} / \mathrm{L}$ as a non-enforcable goal for sulfate in drinking water to limit hardness, corrosiveness to metals, and taste owing to salinity. Sources of sulfates include gold, uranium and copper mines (Maree et al.,1985; Cork,1978).

Sulfur species with oxidation states intermediate between sulfide and 
sulfate $\left(\mathrm{SO}_{4}{ }^{2-}\right.$ ) include (in order of increasing valence) : elemental sulfur $\left(\mathrm{S}^{\circ}\right)$, thlosulfate $\left(\mathrm{S}_{2} \mathrm{O}_{3}{ }^{2-}\right)$ and sulfite $\left(\mathrm{SO}_{3}{ }^{2-}\right)$.

\subsection{Sulfide Control}

Sulfide can be chemically oxidized to sulfate by hypochlorites, chlorine, potassium permanganate, hydrogen peroxide and oxygen. Hydrogen peroxide and oxygen react slowly with sulfide but produce no chemical residue. Hypochlorite and chlorine react to form chloride ions. Permanganate leaves behind manganese oxide. At $\mathrm{pH}$ values greater than 7 , the product of the oxidation is always sulfate (Cadena et al.,1988). The chemical oxidizers are expensive and energy intensive (Kobayashi et a1.,1983).

The partial oxidation of $\mathrm{H}_{2} \mathrm{~S}$ to $\mathrm{S}^{\circ}$ instead of sulfate has several advantages. Elemental sulfur is an easily handled and transported noncorrosive solid containing more sulfur per weight than any other form. Also, the agriculture use of elemental sulfur as a nutrient and fungicide is increasing. Finally, even if sulfate could be refined into a cormerclal product such as $\mathrm{CaSO}_{4}$ (gypsum wallboard) or $\mathrm{H}_{2} \mathrm{SO}_{4}$ (sulfuric acid) It was worth $\$ 36.00 /$ ton in 1978 . Elemental sulfur at that time sold for $\$ 110.00 /$ ton (Cork, 1978).

For these reasons, petroleum refinerles convert $\mathrm{H}_{2} \mathrm{~S}$ liberated in their processes to elemental sulfur. This is most commonly done by the Claus process (Cork et al.,1986). In the first step of the claus process, $\mathrm{H}_{2} \mathrm{~S}$ is partially burned to $\mathrm{SO}_{2}$ with air. The $\mathrm{H}_{2} \mathrm{~S} / \mathrm{SO}_{2}$ mixture is then reacted over a bauxite catalyst to yield $s^{\circ}$ and water. Normally 90-958 of the $\mathrm{H}_{2} \mathrm{~S}$ is converted to $\mathrm{S}^{\circ}$. The remaining $\mathrm{H}_{2} \mathrm{~S}$ is either 
Incinerated to $\mathrm{SO}_{2}$ or converted to sulfur in a tail gas treating unit (Sitting, 1978). Alternatively, the Holmes-Stretford process oxidizes $\mathrm{H}_{2} \mathrm{~S}$ to $\mathrm{S}^{\circ}$ using a vanadium catalyst in water. Over $99 \%$ of the $\mathrm{H}_{2} \mathrm{~S}$ is removed in this process (Vasan,1978).

Cork et al.(1986) have listed several reasons for the high cost of sulfur recovery processes:

(1) The accumdation of soluble sulfates and thiosulfates in the reaction Ilquid (Holmes-stretford process) leads to catalyst poisoning, corrosion and lower elemental sulfur production.

(2) The cost of the chemicals, especially the amine solution (Claus process) and the ADA solution (Holmes-Stretford Process).

(3) The expense of tallgas cleanup which is necessary in most claus plants and the disposal of the slag waste generated during cleanup.

(4) Catalyst Iifetime is limited for both the bauxite and the vanadium.

(5) The $\mathrm{CO}_{2}$ gas saturation in the amine strippers in the claus process requires greater amounts of lean amine solution.

Petroleum refinery operations produce sour water whenever steam is condensed in the presence of gases containing $\mathrm{H}_{2} \mathrm{~S}$ (Sitting, 1978). Condensates from gas separators may contain up to $5000 \mathrm{mg} / \mathrm{L}$ sulfide (Nemerow, 1978). The $\mathrm{H}_{2} \mathrm{~S}$ can be removed by sour water stripping (Flgure 1.1). Steam is contacted with heated sour water in the sour water stripper. Sour gas containing some steam leaves the top of the stripper and is partly condensed. Condensate and sour gas are separated in the surge tank. The sour gas is then sent to a sulfur recovery plant (Claus process). The water from the bottom of the stripping colum is directed to the wastewater treatment plant (Sitting,1978) where $\mathrm{H}_{2} \mathrm{~S}$ may escape from 


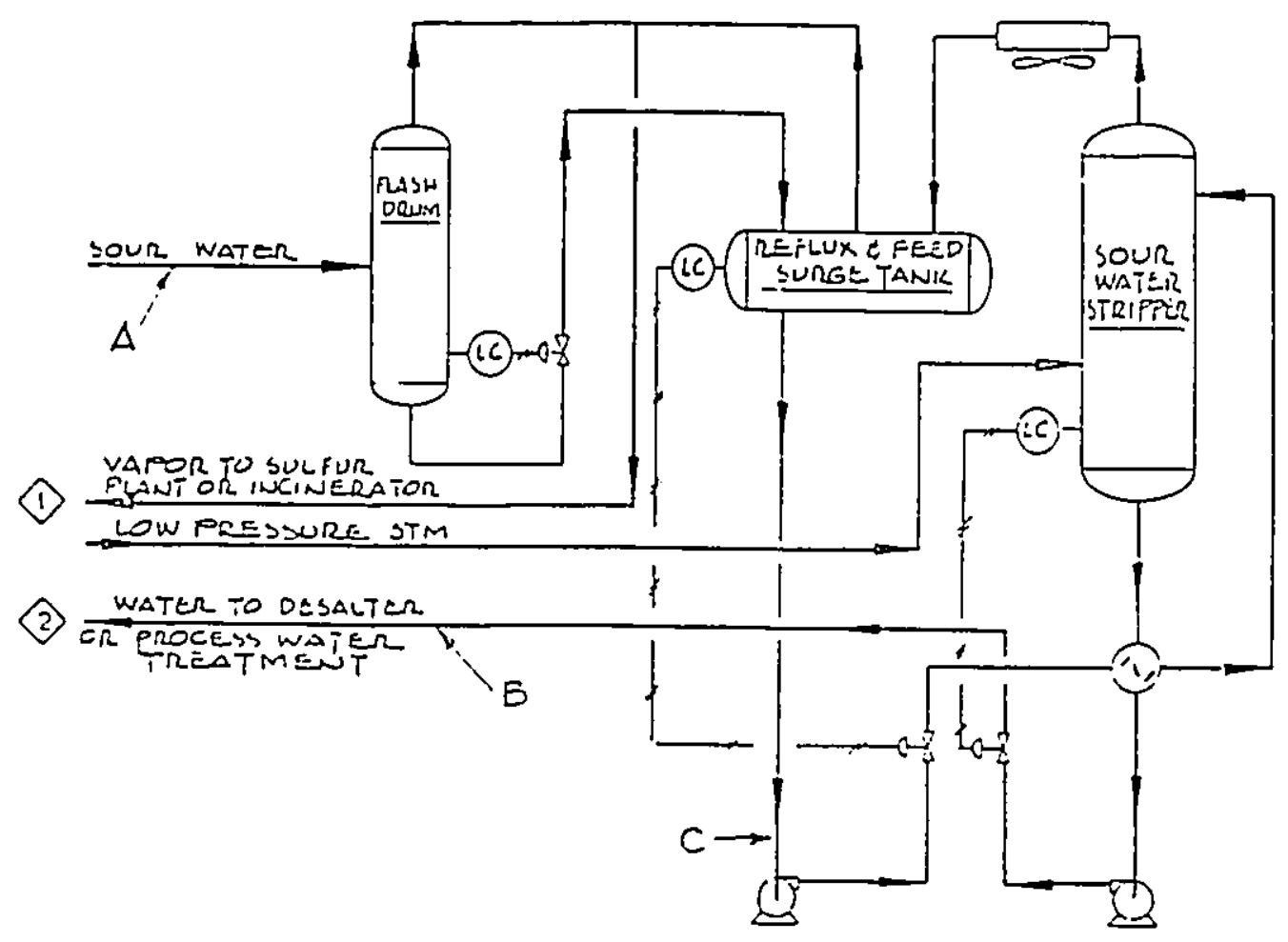

FIGURE 1.1 The Sour Water Stripping Process (Sitting, 1978) 
open channels or be oxidized to $\mathrm{SO}_{4}{ }^{2-}$.

A process which converts the $\mathrm{H}_{2} \mathrm{~S}$ in the feed to the wastewater treatment plant to $S^{\circ}$ can offset its operating costs by the production and sale of elemental sulfur. Such a process can be modified to replace both the sour water stripper and the sulfur recovery processes.

\subsection{Objective}

The objective of this research was to develop a bioprocess to remove $\mathrm{H}_{2} \mathrm{~S}$ from the feed to the sour water stripper and convert it to elemental sulfur.

\subsection{Scope}

The scope of this study was to:

- select and calibrate appropriate analytical methods for different sulfur species and confirm that other sulfur species do not interfere in the analysis;

- demonstrate and quantify the production of elemental sulfur from sulfide in a biological batch reactor;

- quantify the growth rate of bacteria and the maximum tolerable level of sulfide for the selected microorganism in the batch biological reactor; and

- determine the rate of sulfide utilization in the batch biological reactor. 


\section{GHAPTER TWO}

\section{LITERATURE REVIEN}

\subsection{Sulfur Cycle}

The turnover of sulfur compounds in the biosphere is referred to as the sulfur cycle. Sulfur enters the blosphere as $\mathrm{H}_{2} \mathrm{~S}$ from volcanic activity, eg. sulfur springs, (Stanler et al.,1957) or through weathering of minerals contalning sulfate (Anderson,1978).

The cyclic transformations from $\mathrm{H}_{2} \mathrm{~S}$ to $\mathrm{S}^{\circ}$ to $\mathrm{SO}_{4}^{2-}$ and back to $\mathrm{H}_{2} \mathrm{~S}$ are accomplished entirely by bacteria in a sulfuretum (Figure 2.1). Several ecological niches are formed by the combination of anaerobosis, light, sulfur, carbon dioxide and organic materlal.

An anaerobic zone is formed in meromictic lakes (lakes which undergo incomplete circulation) or during stratification in homomictic lakes (lakes that undergo a complete circulation) or at the bottom of any body of water due to the pressure of mud and sand which act as a mechanical barrier to mixing and oxidation (Maka,1986). Sulfates and organic matter from surface run-off and domestic and industrial wastes enter the anaerobic zone where they are converted to $\mathrm{H}_{2} \mathrm{~S}$ by sulfate reducing bacterla such as members of the genus Desulfovibrio. These chemoheterotrophs derive their energy from breaking down and oxidizing organic molecules. Organic matter is also the source of carbon for their new cell materlal. The $\mathrm{H}_{2} \mathrm{~S}$ gas produced by these bacterla rises through the water column.

Closer to the surface, but still in the anaerobic zone, the anoxygenic photosynthetic bacterla which include the green sulfur 
Addilions of oryanic maller. sulfihale:s and other salts initiates anacrobic condilions

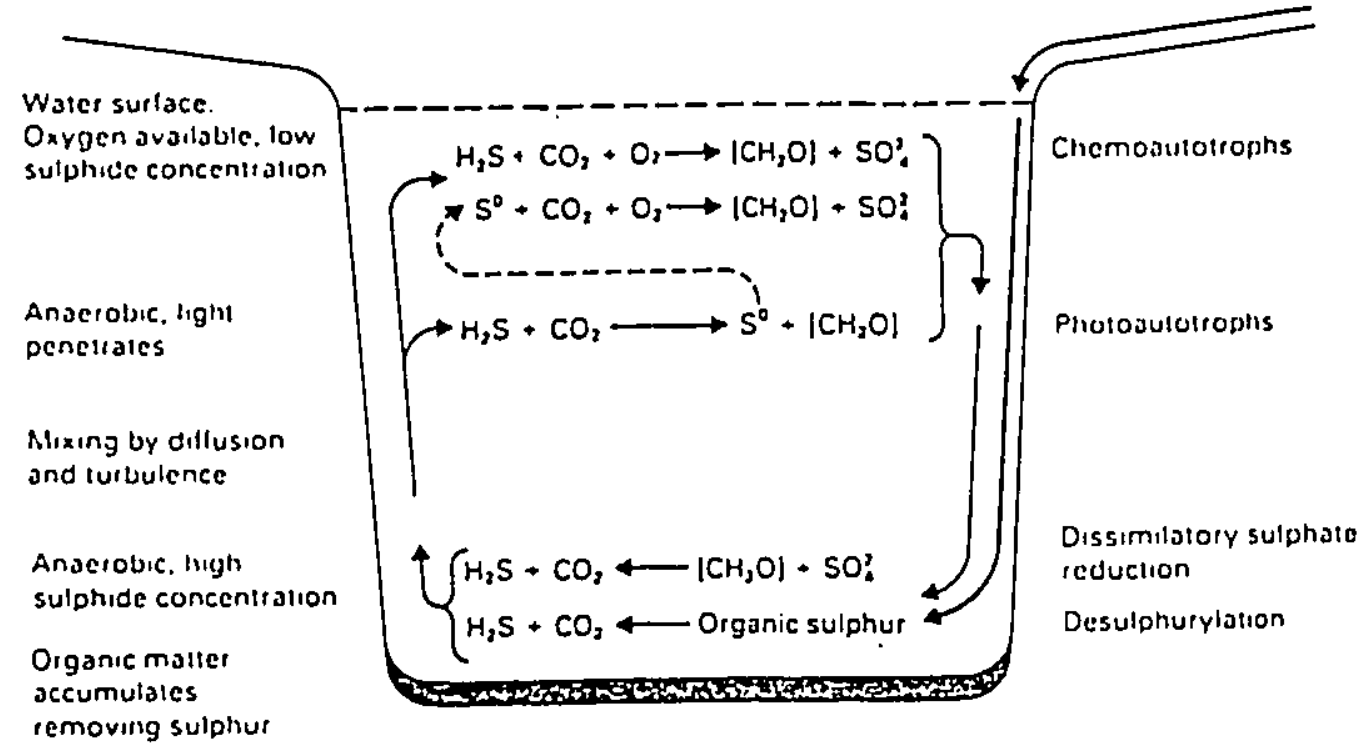

FIGURE 2.1 Bacterial Interactions in a Sulfuretum (Madigan et al.,1988) 
bacteria, purple sulfur bacteria and purple non-sulfur bacteria are present. The purple and green sulfur bacteria are photoautotrophs, using the infra-red light avallable at anaerobic depths as their energy source and carbon dioxide as their carbon source. Green plants assimilate carbon according to the equation:

$$
2 \mathrm{nH}_{2} \mathrm{O}+\mathrm{nOO}_{2} \underset{21 \text { qnt }}{\longrightarrow}\left(\mathrm{CH}_{2} \mathrm{O}\right)_{n}+\mathrm{nO}_{2}+\mathrm{nH}_{2} \mathrm{O}
$$

On the other hand, anoxygenic photosynthetic bacteria fix carbon but produce no molecular oxygen (Maka, 1986):

$$
2 \mathrm{nH}_{2} \mathrm{~S}+\mathrm{nOO}_{2} \underset{210 \mathrm{mt}}{\longrightarrow}\left(\mathrm{CH}_{2} \mathrm{O}\right)_{n}+2 \mathrm{nS}^{\circ}+\mathrm{nH}_{2} \mathrm{O}
$$

Sulfide in $\mathrm{H}_{2} \mathrm{~S}$ replaces oxygen in water as the source of four electrons that are transferred to carbon. Some cyanobacteria (Garlick et al.,1977) and algae (Knoblock,1966) perform photosynthesis by both paths simultaneously. Most purple and green bacteria oxidize elemental sulfur to sulfate (Stanier et $a 1 ., 1957$ ) and eventually make it available to the sulfate reducing bacteria.

Hydrogen sulfide which reaches the aerobic zone of the lake is oxidized spontaneously by $\mathrm{O}_{2}$ (Stanier et al.,1957) but this reaction is slow (Buisman et al.,1989). Chemolithotrophs use the energy of this oxidation to drive their metabolism and also fix carbon from inorganic sources such as carbon dioxide. These colourless sulfur bacteria ultimately produce sulfate as the end-product of sulfide metabolism (Gaudy et al.,1980). This sulfate along with decayed biomass from the photo- and chemolithotrophs feed the sulfate reducing bacteria to complete the sulfur cycle. 


\subsection{Sulfide Oxidizing Bacteria}

The desirable bacterium for the bioprocess under investigation should produce $s^{\circ}$ from sulfide in such a manner that the elemental sulfur is easily extractable from the biomass.

\subsubsection{Aeroblc Chemollthotrophs}

The colourless sulfur bacteria include the genera Beggiatoa, Thiothrix and Thiobacillus.

Thiothrix and Beggiatoa are genera of the family Beggiatoacea within the "non-photosynthetic, non-fruiting gliding bacteria" (Tortora,1989). Intracellular granules of elemental sulfur were formed in the presence of $\mathrm{H}_{2} \mathrm{~S}$. When the sulfide supply is depleted, the $\mathrm{S}^{\circ}$ dissappears (Stanler et 21.,1957). In this way, $S^{\circ}$ acts as an energy-storage medium in the oxidation of sulfide to sulfate. Extracting sulfur, whether by chemical or physical methods, would reguire rupturing the cell membrane, rendering the cell useless for further sulfur production.

There is some debate whether the Thlobacilli produce $S^{\circ}$ or oxidize $\mathrm{H}_{2} \mathrm{~S}$ completely to sulfate. Gaudy et al.(1980) states," all thiobacillus species are small rods, and the sulfur is deposited outside the cell. The final product of oxidation is sulfate." Whereas Roy et al.(1970) note, "accumulation of elemental sulfur however, does not invarlably accompany sulfide oxidation by thiobacil1i."

Thiobacillus denitrificans (abrv. T. denitrificans) can use the reduction of nitrate to molecular nitrogen as an energy source while oxidizing $s^{\circ}$ or thiosulfate (Gaudy et al.,1980). Sublette et al. $(1987 \mathrm{a}, \mathrm{b})$ demonstrated the use of $T$. denitrificans to oxidize 1 mole $\% \mathrm{H}_{2} \mathrm{~S}$ in a nitrogen gas feed stream. No elemental sulfur was detected in the 
reactor. This process was later demonstrated to be suited to desulfurize natural gas (Sublette et al.,1987c). London (1964) concluded that $S^{\circ}$ is not a normal intermediate product of sulfide or thiosulfate oxidation for T. thioparus, T. thiooxidans and T. Intermedius. Karavaiko (1977) photographed inclusions in $T$. neapolitanus which were analyzed by $x$-ray diffraction and found to contain elemental sulfur.

Thiobacillus has been used successfully to treat sulfide-rich wastewaters from Soviet spas. Over $95 \%$ of the influent sulfide was converted to sulfate by $T$. thioparus and $T$. thiooxidans in an upflow reactor. Influent $\mathrm{H}_{2} \mathrm{~S}$ concentrations of $20-60 \mathrm{mg} / \mathrm{L}$ were oxidized to less than $1 \mathrm{mg} / \mathrm{L}$ in the effluent (Ass et al.,1983).

Rozek (1978) patented a process for oxidizing sulfide in sulfur mine wasterwater. Inorganic nutrients and $T$. thioparus were added to the wastewater. After oxidation, the water surface was covered with a layer of elemental sulfur and bacterial cells.

Recently, Thiobacillus has been demonstrated to convert sulfide to $\mathrm{s}^{\circ}$. Thiobacillus growth wes promoted from an initial innoculum of ditch mud in an upflow aerobic completely mixed and continuously fed reactor. Sodium sulfide and inorganic nutrients were added to tap water and $\mathrm{pH}$ stabllized before being fed into the reactor. Pure oxygen was bubbled into the reactor. On average, 818 of the influent sulfide was converted to $\mathrm{S}^{\circ}$, whereas $13 \%$ became sulfate (Buisman et al,,1989).

Subsequently, the following observations were made using a $20 \mathrm{~L}$ reactor with an aeration stone to produce finer bubbles (Buisman et al., 1990):

(1) At a sulfide loading rate of $832 \mathrm{mg} / \mathrm{L} \cdot \mathrm{d}, 86 \%$ of the influent sulfide 
was converted to $\mathrm{S}^{\circ}$ and approximately 18 of the influent sulfide became sulfate. The sulfide concentration in the reactor effiuent was $9-22 \mathrm{mg} / \mathrm{L}$.

(2) At a sulfide loading rate of $1040 \mathrm{mg} / \mathrm{L} \cdot \mathrm{d}, 698$ of the influent sulfide was converted to $s^{\circ}$ but no sulfate was formed. The effluent sulfide concentration was $43 \mathrm{mg} / \mathrm{L}$.

(3) At a sulfide loading rate of $520 \mathrm{mg} / \mathrm{L} \cdot \mathrm{d}, 88 \%$ of the sulfide was converted to elemental sulfur but $7 \%$ was converted to sulfate resulting in the removal of $95 \%$ of the influent sulfide. The reactor effluent contained $2 \mathrm{mg} / \mathrm{L}$ sulfide.

There was a compromise between efflueint sulfide concentration and sulfate formation. A 1008 conversion of all of the removed sulfide to $s^{\circ}$ was achieved only when sulfide appeared in the effluent. On the other hand, a low sulfide effluent concentration was realised only when sulfate appeared in the effluent. Results were similiar for the blorotor reactor tested. Although these bactexia deposit sulfur extracellularly, $100 \%$ removal of $\mathrm{H}_{2} \mathrm{~S}$ and conversion to $\mathrm{S}^{\circ}$ had not been achieved.

\subsubsection{Anaeroblc Photolithotrophs}

The purple and green bacterla contain bacteriochlorophylls (bchl) which are responsible for light harvesting and transferring energy to the photochemical reaction centre (Stanier et al.,1976). It is the type and abundance of these photosynthetic pigments which give the bacteria their characteristic colour.

\subsubsection{Purple Kon-Sulfur Bacteria}

Purple bacteria contain either bchl a or bchl b. This group of bacterla are termed "non-sulfur" because its members were historically 
found not to metabolize sulfide, that is, they did not produce sulfur granules in the presence of sulfide (Hansen et al.,1972). These bacterla are present in sulfureta because they can metabolize sulfur-containing organic compounds, using the reduced sulfur as their electron source and the bound carbon as their carbon source. Therefore, they are called photoheterotrophs (Gaudy et al.,1980). This explains their dominance over purple and green sulfur bacteria in sewage sludge (Slefirt et al.,1978).

Some species of Rhodospirillum and Rhodopseudomonas have been found to oxidize sulfide and produce extracellular sulfur without production of sulfate. Rhs. capsulata tolerated $2 \mathrm{mM}(64 \mathrm{mg} / \mathrm{L})$ sulfide in an inorganic medium with growth factors (biotin, niacin, thiamin, potassium-p-aminobenzoate) and $3.2 \mathrm{~mm}(102 \mathrm{mg} / \mathrm{L})$ sulfide when yeast

extract was added. Growth in a completely inorganic medium was not reported (Hansen et al.,1972). It is doubtful that these bacteria can continuously metabolize sulfide without the addition of expensive and possibly sensitive growth factors.

\subsubsection{Purple Sulfur Bacteria}

Sulfur granules accumulate inside the cells of these motile anaerobes (Roy et al.,1970). The genera Thiocapsa and Chromatium are included in this family.

Slaughter-house effluent was found to turn pink owing to Thiocapsa roseopersicina, the major sulfide oxidizing bacteria present (Cooper et a1.,1975). Sulfide oxidation by Chromatium okenii was found to be dependent on the presence of carbon dloxide, and the conversion was reversible (Truper et al.,1964). As with Beggiataa and Thiothrix, these bacteria store sulfur intracellularly and consequently make it 
inaccessible by simple separation methods.

\subsubsection{Green Sulfux Bacteria}

The green sulfur bacteria (GSB) contain a major light harvesting pigment, bchl $c, d$ or $e$, and a minor chlorophyll at the photochemical reaction centre which is always bchl a (stanler et al.,1976). These strictly anaerobic non-motile bacteria oxidize sulfide and deposit $\mathrm{s}^{\circ}$ extracellularly (Roy et al.,1970). Several species of the genus Chlorobium have been studied.

C. phaebacteriodes had tolerated sulfide levels up to $5 \mathrm{mM}(160 \mathrm{mg} / \mathrm{L})$ in the laboratory but was not found in its natural habitat at sulfide levels less than 0.03 to $0.06 \mathrm{mM}$ (1 to $2 \mathrm{mg} / \mathrm{L}$ ) sulfide (Bergstein et al.,1983). Chlorobium limicola forma specialis thiosulfatophilum (also known as Chlorobium thiosulfatophilum) can utllize thiosulfate as well as sulfide as an electron source (Roy et al.,1970).

The mechanism of subsequent conversion of $S^{\circ}$ to sulfate is not fully known. Cork (1978) has postulated the reaction :

$$
\mathrm{S}^{\mathrm{O}}+3 \mathrm{H}_{2} \mathrm{O} \longrightarrow \mathrm{SO}_{2}^{2-}+6 \mathrm{H}^{+}+4 \mathrm{e}^{-}
$$

Evidence for this reaction is weak. Truper (1982) has suggested the disproportionation of elemental sulfur:

$$
4 \mathrm{~S}^{\circ}+3 \mathrm{H}_{2} \mathrm{O} \longrightarrow 2 \mathrm{H}_{2} \mathrm{~S}+\mathrm{H}_{2} \mathrm{~S}_{2} \mathrm{O}_{3}
$$

c. thiosulfatophilum possesses a thiosulfate-splitting enzyme which can convert thiosulfate to sulfite:

$$
\mathrm{S}_{2} \mathrm{O}_{3}^{2-}+2 \mathrm{e}-\longrightarrow \mathrm{S}^{2-}+\mathrm{SO}_{3}^{2-}
$$

The mechanism of oxidation of sulfite to sulfate is identical to the pathway employed by Thiobacillus:

$$
\mathrm{SO}_{3}^{2-}+\mathrm{AMP} \longrightarrow \mathrm{APS}+2 \mathrm{e}-
$$




$$
\mathrm{APS}+\mathrm{PO}_{4} 3-\longrightarrow \mathrm{ADP}+\mathrm{SO}_{4}=-
$$

AMP, ADP and ATP are adenosine mono, $d i$, and triphosphate respectively. APS is adenylylsulfate. AMP is regenerated:

$$
2 \mathrm{ADP} \longrightarrow \mathrm{ATP}+\mathrm{AMP}
$$

Phosphate is regenerated by cleaving ATP, a hydrolytic process. Thus, the source of the oxygen for conversion of $S^{\circ}$ to sulfate is water.

Brune (1982) traced the oxidation of sulflde using an lon-selective electrode. Van Gemerden (1986) found that extracellular sulfur secreted by c. thiosulfatophilum remained attached to the cells and was not easily available to other microorganisms. C. thiosulfatophilum inhibited to one half its maximum specific growth rate at a sulfide concentration of 3-4 mM (96-128 mg/L) (Van Gemerden, 1984). Mathers et al., (1985) noted that low growth rates of $c$. thiosulfatophilum occurred in sulfide concentrations above $6 \mathrm{mM}(192 \mathrm{mg} / \mathrm{L})$.

Maree et al.(1985,1986,1987) used an upflow anaerobic packed-bed reactor In serles with a photosynthetic reactor to remove sulfate from mine wastewater. Sulfate was reduced to $\mathrm{H}_{2} \mathrm{~S}$ in the first reactor, and purple and green sulfur bacteria precipitated sulfur in the second reactor. Sulfur yield was not quantified. Kobayashi et al. (1983) tested a fixed film upflow photosynthetic reactor and a phototube (plug-flow reactor) for removal of $\mathrm{H}_{2} \mathrm{~S}$ from anaerobic filters. Chlorobium was identified as the common organism in the phototube. Sulfide removal ranged from 70-95\% in the colum and $99.9 \%$ in the phototube (showing excess capacity). Sulfate the product of oxidation in both reactors. Cork (1987) patented a process for 95-98\% removal of $\mathrm{H}_{2} \mathrm{~S}$ from natural gas streams containing 0.1 to $65 \% \mathrm{H}_{2} \mathrm{~S}$. The natural gas was to be bubbled 
through a nutrient medium containing C. thiosulfatophilum. Cork(1978) also tested chromatium vincsum and C. thiosulfatophilum in the photosynthetic reactor of a two-stage process that converted $90 \%$ of the influent sulfate to $\mathrm{S}^{\circ}$. Sulfate was reduced to $\mathrm{H}_{2} \mathrm{~S}$ by Desulfovibrio desulfuricans in the first stage. The $\mathrm{H}_{2} \mathrm{~S}$ gas was carried by an inert gas into the photosynthetic reactor for production of $s^{\circ}$ C. thiosulfatophilum was found to be superlor to Chromatium in the following categories :

-production of $s^{\circ}$ per unit time

-ratio of $s^{\circ}$ produced to other oxidized forms of sulfur produced

-ratio of $\mathrm{S}^{\circ}$ produced to sulfate input

- tolerance to high sulfide concentration $(>4 \mathrm{~mm}(128 \mathrm{mg} / \mathrm{L}))$

- extracellular production of $\mathrm{s}^{\circ}$

Cork claimed that the extracellular $\mathrm{s}^{\circ}$ could be easlly isolated by differential centrifugation (Cork, 1978) or rotary filtration (Cork, 1987). The optimum $\mathrm{pH}$ and temperature were found to be 7.0 and $30^{\circ} \mathrm{C}$ respectively for C. thiosulfatophilum. This process was later patented (Cork,1984) as a means of removing sulfate from copper mining wastewater.

\subsubsection{Sumary of Previous Hork}

Cork's $(1978,1984,1987)$ work demonstrated the utility of the green sulfur bacterium C. thiosulfatophilum in producing $\mathrm{S}^{\circ}$ from $\mathrm{H}_{2} \mathrm{~S}$. However, the sulfide fed into the photosynthetic reactor was in the gas phase.

Maree et al.(1985,1986,1987) and Kobayashi et al.(1983) demonstrated the removal of sulfide in the liquid phase by photosynthetic bioprocesses, but sulfur was either not quantified or not produced.

In sour water the $\mathrm{H}_{2} \mathrm{~S}$ is present in the IIquid phase. While 
dissoived in water, $\mathrm{H}_{2} \mathrm{~S}$ is less likely to be an environmental or safety hazard than $\mathrm{H}_{2} \mathrm{~S}$ gas. Thus, it is advantageous to convert sulfide directly to $s^{\circ}$ while in the liquid phase. This has not been attempted within a bloreactor.

\subsection{Quantitative Description of Gowth}

Bacterial growth typically conforms to several phases (Figure 2.2). In the logarithmic growth phase, the increase in microbial population conforms to the equation:

$$
\frac{d x}{d t}=\mu x
$$

where $x=d r y$ weight of the blomass in the population (mg/L)

$t=$ time $(h)$

$\mu=$ specific growth rate $\left(h^{-2}\right)$

Upon integration between times $t_{1}$ and $t_{2}$, the specific growth rate becomes (Gaudy et al., 1980):

$$
\mu=\frac{\ln x_{t_{2}}-\ln x_{t_{2}}}{t_{2}-t_{1}}
$$

The specific growth rate depends on the substrate present at the beginning of the growth phase. Thls dependancy conforms to the Monad equation (Gaudy et al.,1980):

$$
\mu=\frac{\mu_{\max } S}{K_{p}+S}
$$

where $\mu_{-m}=$ maximum specific growth rate $\left(\mathrm{h}^{-1}\right)$

$\boldsymbol{s}=$ substrate concentration $(\mathrm{mg} / \mathrm{L})$

$K_{s}=$ substrate concentration at $\psi_{k} \mu_{\max }(\mathrm{mg} / \mathrm{L})$

When the substrate at higher concentrations also becomes a growth 


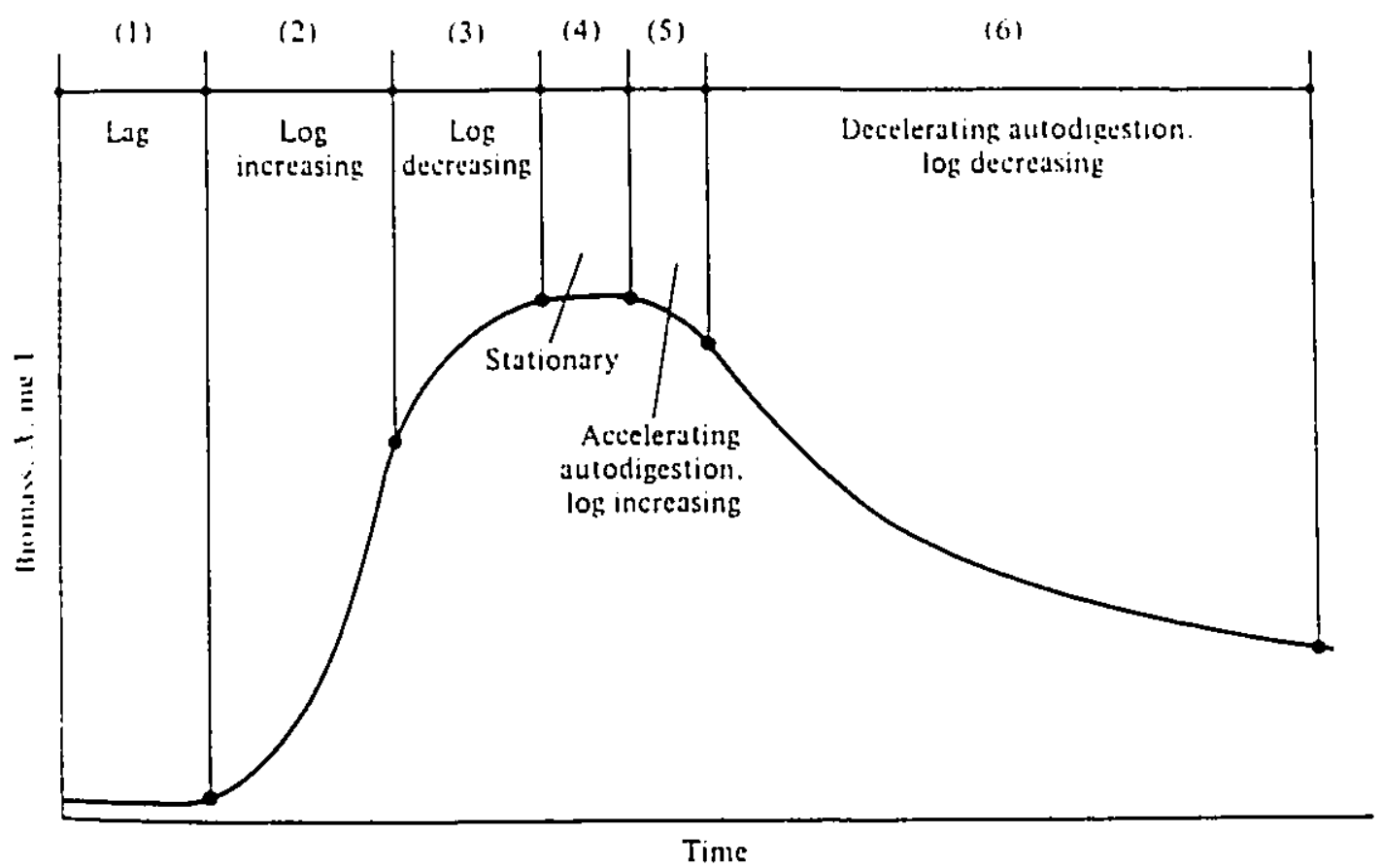

FIGURE 2.2 The Biomass Growth and Decay Curve (Gaudy et al., 1980) 
Inhibitor, the Haldane equation applies (Gaudy et al.,1980):

$$
\mu=\frac{\mu_{\text {max }} s}{\left(K_{g}+S\right)\left(1+\frac{S}{K_{1}}\right)}
$$

where $\quad x i=$ inhibition constant $(\mathrm{mg} / \mathrm{L})$

The cell yield $(Y)$ is the mass of cells produced per unit of substrate utilized (Gaudy et al.,1980):

$$
Y=\frac{X_{t_{2}}-X_{t_{1}}}{S_{t_{2}}-S_{t_{2}}}
$$

The value of the yield for heterogeneous populations of bacteria of sewage sludge origin growing on various carbon sources is generally 0.4 to 0.6. This value decreases as the bacteria leave the substrate utilization ( $\log$ growth) phase. A measure of cell yield taken during or at the end of the substrate removal period is called the true cell yield, $Y_{t}$ (Gaudy et al.,1990).

\subsection{Substrate Utilization}

The rate of substrate utilization per unit concentration of biomass is termed as the specific substrate utilization rate (Gaudy et al, 1980):

$$
U=\frac{d s}{d t} \frac{1}{x}
$$

$$
\text { where } \begin{aligned}
& \boldsymbol{U}=\text { specific substrate utilization rate }\left(\mathrm{h}^{-1}\right) \\
& \mathrm{d} S=\text { decrease in substrate concentration }(\mathrm{mg} / \mathrm{L}) \\
& \mathrm{d} t=\text { change in time }(\mathrm{h}) \\
& \boldsymbol{x}=\text { biomass concentration }(\mathrm{mg} / \mathrm{L})
\end{aligned}
$$


CHAPTER THREB

MATERINS AND MEHWODS

\subsection{Methods of Analysis}

Throughout this section, $\mathrm{diH}_{2} \mathrm{O}$ refers to distilled water of conductivity 5 to $7 \mu \mathrm{mho} / \mathrm{cm}$, and $\mathrm{deH}_{2} \mathrm{O}$ refers to delonized or distilled, deionized water with a conductivity of less than $1.3 \mu \mathrm{mho} / \mathrm{cm}$.

All absorbance measurements were made with a Pye Unicam SP500 Serles 2 spectrophotometer in the direct readout mode using a $10 \mathrm{~mm}$ quartz cuvette. All absorbance measurements are reported in optical density units (O.D.). An International centrifuge Centra-4 centrifuge with a \#215 rotor was used in the sulfate and bacterlochlorophyll assays.

\subsubsection{Sulfide}

The method of Truper et al. (1964) was modified slightly (Section A.2.3 in Appendix A) and used as follows:

\subsubsection{Reagents}

A. Zn Solution

Roughly $19.1 \mathrm{~g}$ zinc acetate ( $\mathrm{Zn}$ (acetate) $)_{2} \cdot 2 \mathrm{H}_{2} \mathrm{O}$ ) crystals were added to an $800 \mathrm{~m}$ glass bottle. The bottle was capped and shaken after $0.8 \mathrm{~L}$ of $\mathrm{deH}_{2} \mathrm{O}$ was added. The solution was shaken immediately before use.

\section{B. DPD Solution}

Exactly $2.00 \mathrm{~g}$ of dimethyl-p-phenylenediamine sulfate (DPD) were added to $1.00 \mathrm{~L}$ of $20 \% \mathrm{H}_{2} \mathrm{SO}$ ( $200 \mathrm{~mL}$ conc. $\mathrm{H}_{2} \mathrm{SO}_{4}+800 \mathrm{~mL} \mathrm{deH}_{2} \mathrm{O}$, cooled) in a beaker and stirred. The mixture was poured into a dark glass bottle for storage. 


\section{c. FAS Solution}

Approximately $18.1 \mathrm{~g}$ of ferric ammonium sulfate $\left(\mathrm{FeNH}_{4}\left(\mathrm{SO}_{4}\right)_{2} \cdot 12 \mathrm{H}_{2} \mathrm{O}\right.$ ) were dissolved in $200 \mathrm{~mL} \mathrm{deH}_{2} \mathrm{O}$, then $20 \mathrm{~mL}$ of conc. $\mathrm{H}_{2} \mathrm{SO}_{4}$ and $0.78 \mathrm{~L}$ of $\mathrm{deH}_{2} \mathrm{O}$ were added to the solution.

\subsubsection{Procedure}

A graduated cylinder was used to measure $20 \mathrm{~mL}$ of the $\mathrm{Zn}$ solution into a $100.00 \mathrm{~m}$ volumetric flask. A 1 cc plastic syringe graduated to $0.01 \mathrm{~mL}$ (Becton Dickinson) with a $7 \mathrm{~cm}$ metal needle was rinsed thrice with the sample and filled. The syringe was inverted into a $100.00 \mathrm{~mL}$ volumetric flask so that the tip of the needle was less than $1 \mathrm{~cm}$ from the zinc solution. Between 0.10 and $0.95 \mathrm{~mL}$ of sample (as much as possible but within the range of the method) was squeezed into the $\mathrm{zn}$ solution. The volumetric flask was swirled, and $10.00 \mathrm{~mL}$ of DPD solution followed by $0.50 \mathrm{~mL}$ of FAS solution were pipetted into the volumetric flask. The flask was made up to the mark with $\mathrm{diH}_{2} \mathrm{O}$, capped and inverted several times. After a waiting period of at least 30 minutes (sometimes overnight) the absorbance was measured at $670 \mathrm{~nm}$ against $\mathrm{diH}_{2} \mathrm{O}$.

\subsubsection{Calculation}

The O.D.s7o value was converted to $\mathrm{s}^{2-}$ concentration using a calibration equation obtained in the laboratory (see Section A.2.3 in Appendix A):

$$
\begin{aligned}
& \mathrm{mgs}^{2-} / \mathrm{L} \text { in sample }=\frac{100.00}{\mathrm{~mL} \text { 8ample }}\left[\frac{0 . \mathrm{D.670}-0.001}{1.161} \pm 0.022\right] \\
& \text { range }=0 \text { to } 750 \mathrm{mgs}^{2-} / \mathrm{L} \text { in sample } \\
& 0 . D .670<0.86 \text { in cuvette }
\end{aligned}
$$




\subsubsection{Elemental Sulfur}

The colorimetric method of Bartlet et al. (1954) was modified (Section A.3.2 in Appendix A) to be used on aqueous samples.

\subsubsection{Reagents}

A. $\mathrm{HgCl}_{2}$ solution

Approximately $25 \mathrm{~g} \mathrm{HgCl}_{2}$ and $25 \mathrm{~g} \mathrm{KCl}$ were added to a $1.5 \mathrm{~L}$ erlenmeyer Elask. One (1.00) $\mathrm{L} \mathrm{deH}_{2} \mathrm{O}$ was added, and the mixture was covered with parafilm and stirred to dissolve.

\section{B. Acetone Solution}

Exactly $25.00 \mathrm{~mL}$ of $\mathrm{deH}_{2} \mathrm{O}$ was pipetted into a $500.0 \mathrm{~mL}$ volumetric flask. Acs grade acetone was added to the mark and the solution was capped and inverted. Some additional acetone may have been added to compensate for the reduction in volume on mixing.

C. NaCN Solution

Roughly $5.0 \mathrm{~g}$ of sodium cyanide (NaCN) were added to $500.0 \mathrm{~mL}$ of acetone solution in a $1 \mathrm{~L}$ erlenmeyer flask. The mixture covered with parafilm and stirred to dissolve.

D. FeCl, Solution

Approximately $0.80 \mathrm{~g}$ ferric chloride hexahydrate $\left.(\mathrm{FeCl}]_{3} \cdot 6 \mathrm{H}_{2} \mathrm{O}\right)$ were added to $200.00 \mathrm{~mL}$ of acetone solution in a $250 \mathrm{~mL}$ erlenmeyer flask. The mixture was corked and allowed to stand overnight to settle an orange precipitate. The supernatant was decanted into a $100 \mathrm{mc}$ screw-cap bottle for storage.

\subsubsection{Procedure}

Exactly $40.0 \mathrm{~mL}$ of $\mathrm{HgCl}_{2}$ solution and a magnetic stir bar were added to a $250 \mathrm{~mL}$ erlenmeyer flask with a $24 / 40$ ground glass Joint. A $10.00 \mathrm{~mL}$ 
sample (or a $5.00 \mathrm{~mL}$ sample and $5.00 \mathrm{~mL} \mathrm{deH}_{2} \mathrm{O}$ ) was pipetted into the $\mathrm{HgCl}_{2}$ solution. A tefion or glass stopper was inserted after $20.00 \mathrm{~mL}$ of $35-60$ petroleum ether were added. The stopper was sealed with parafilm and the mixture was stirred for 45 to 60 minutes. The petroleum ether layer was decanted into a test tube or $25 \mathrm{~m}$ graduated cylinder. A $5.00 \mathrm{~mL}$ pipette was rinsed with the organic layer and fllled. This solution was transferred to a $25.00 \mathrm{~mL}$ volumetric flask and $15.00 \mathrm{~mL}$ of NaCN solution were added. The solution was made up to the mark with acetone solution, covered and inverted twice. A $5.00 \mathrm{~m}$ pipette was thrice rinsed with this solution and $5.00 \mathrm{~mL}$ were transferred to a test tube. Exactly $5.00 \mathrm{~mL}$ of FeCls solution were added to the test tube and the absorbance was measured at $465 \mathrm{~nm}$ against a blank consisting of $5.00 \mathrm{~mL}$ of $\mathrm{FeCl}$ s solution and 5.00 $m$ of acetone solution. There were three samples taken per draw. Only the average of the three is reported in section 4.1 .

\subsubsection{Calculation}

The O.D.46s value was converted to $S^{\circ}$ concentration using a calibration equation developed in the laboratory (see section A.3.2 in Appendix A):

$$
\begin{aligned}
& \mathrm{mgs}^{\circ} / \mathrm{L} \text { In aample }=\frac{200}{m L \text { sample }}\left[\frac{0 . D \cdot \cos -0.019}{0.2258} \pm 0.24\right] \\
& \text { range }=0 \text { to } 140 \mathrm{mgS}^{\circ} / \mathrm{L} \text { in sample } \\
& 0 . D . A B<1.3 \text { in cuvette }
\end{aligned}
$$

\subsubsection{Sulfate}

The APHA (1989) turbidimetric method was modified slightly (section A.4) and limited in use by concentrations of sulfide and elemental sulfur. 


\subsubsection{Reagents}

A. Buffer $\mathrm{A}$

Approximately $30 \mathrm{~g}$ of magnesium chloride hexahydrate $\left(\mathrm{MgCl}_{2} \cdot 6 \mathrm{H}_{2} \mathrm{O}\right)$, $5 \mathrm{~g}$ of sodium acetate trinydrate $\left(\mathrm{Na}\left(\mathrm{CH}_{3} \mathrm{OOO}\right) \cdot 3 \mathrm{H}_{2} \mathrm{O}\right), 1 \mathrm{~g}$ of potassium nitrate $\left(\mathrm{KNO}_{3}\right)$ and $20 \mathrm{~mL}$ of glacial acetic acld $\left(\mathrm{CH}_{3}, \mathrm{OOH}^{2}\right.$ were added to a $1 \mathrm{~L}$ plastic bottle. One (1.0) $\mathrm{L}$ of $\mathrm{deH}_{2} \mathrm{O}$ was added and the bottle was capped and shaken.

\subsubsection{Procedire}

A portion of the draw from the reactor was centrifuged at $3000 \mathrm{rpm}$ for 30 minutes. A 10.00 (or 5.00 ) mc sample was pipetted into a $250 \mathrm{~mL}$ erlenmeyer flask and 90.0 (or 95.0) $\mathrm{mL}$ of $\mathrm{diH}_{2} \mathrm{O}$ and a magnetic stir bar were added. The timer was started and $20.0 \mathrm{~mL}$ of Buffer A were added. The mixture was stirred mildly for $k$ minute then used to rinse and fill a turbidimetric cuvette. The turbidity $\left(\mathrm{NTU}_{2}\right)$ of this solution was measured at $360 \pm 30$ seconds. At a clock time of 120 seconds, $h \mathrm{~mL}$ of barium chloride $\left(\mathrm{BaCl}_{2}\right)$ crystals were added to the erlenmeyer flask and the solution was stirred vigorously for $60 \pm 2$ seconds. The solution was allowed to stand, used to rinse the cuvette and the turbidity was measured $\left(\mathrm{NTU}_{z}\right)$ at $480 \pm 30$ seconds clock time. Turbidity measurements were made in nephelometric turbidity units with a Hach model 43900 Ratio/XR Turbidimeter.

\subsubsection{Calculation}

The ANTU value was converted to $\mathrm{SO}_{4}{ }^{2--S}$ concentration using a calibration equation developed in the laboratory (see Section A.4 in Append ix A): 


$$
\begin{aligned}
& \Delta N T U=N_{2}-N_{2} \\
& m g S U_{4}^{2-}-S / L \text { in sample }=\frac{120.0}{m L \text { 8ample }}\left[\frac{\Delta N I U+2.0}{13.71} \pm 0.10\right]
\end{aligned}
$$

range $=0$ to $240 \mathrm{mgSO}^{2--S / L}$ in sample ANTU < 148 in cuvette

The concentration expression is read "mg sulfur per $L$ in the form of sulfate." The results of this test are valld for a limited range of $\mathrm{S}^{2-}$ /So values (see Figure A.11 in Appendix A).

\subsubsection{Bacteriochloroghyll}

The method of Maka (1986) was used without modification.

\subsubsection{Procedure}

A pipette was used to dispense $10.00 \mathrm{~mL}$ of methanol into a centrifuge tube. A $1.00 \mathrm{~m}$ sample was transferred by pipette into the methanol. The tube was covered with parafilm, swirled for one minute and centrlfuged at $3000 \mathrm{rpm}$ for 2 minutes. The absorbance of the supernatant was measured at $670 \mathrm{~nm}$ against a methanol blank.

\subsubsection{Calculation}

The 0.D.670 value was converted to bchl concentration using the conversion given by Maka (1986):

$$
\text { mgbchl/L in sample }=127.9[0 . D .670] \pm 0.66
$$

$$
\text { range }=0 . D .670<0.5 \text { has been reported (Uphaus et al.,1983) }
$$

\section{1 .5 pH}

A Fisher Accumet model $210 \mathrm{pH}$ meter and Fischer Universal Glass pH Electrode were used. The electrode/meter was calibrated at pH 7.00 and 
4.00 using Fischer certified buffer solutions. A $15 \mathrm{~mL}$ sample was poured into a $25 \mathrm{~mL}$ plastic graduated cylinder, the electrode was inserted and the $\mathrm{pH}$ value was read from the meter.

\subsection{Apparatus}

\subsubsection{Bacteria}

Chloroblum thiosulfatophilum was ordered from the Amerlca Type Culture collection and subcultured for six months prior to use.

\subsubsection{Reactor}

A New Brunswick Scientific Co. model F-14 fermentor was used as a batch reactor. Valves wiere added to the air inlet, sparger inlet and bottom sampling tube. All other openings were sealed. The stir paddles were removed from a second reactor to clamp a Philips IR 175 att R-PAR bulb inside the reactor. A photograph of the reactor is shown in Figure 3.1 .

Both reactors were mounted in a New Brunswick scientific Co. model FS-314 fermentor drive assembly. The light source mounted in the right position with the light shining toward the centre position. This resulted in an average Illuminance of 2400 lux (see Appendix B). The waterbath was filled with tapwater and bleach was added to inhibit fouling. The thermostat was set to $30^{\circ} \mathrm{C}$. The waterbath temperature was recorded whenever a draw was made from the reactor. The variable speed drive was connected to the medium filled reactor in the centre position with the stirring speed set at $80 \mathrm{rpm}$ during each experiment.

\subsubsection{Medium}

Initially, a Chromatium medium (ATCC, 1985) was used to subculture the ATCC culture of $c$. thiosulfatophilum. Later, the medium of Madigan 


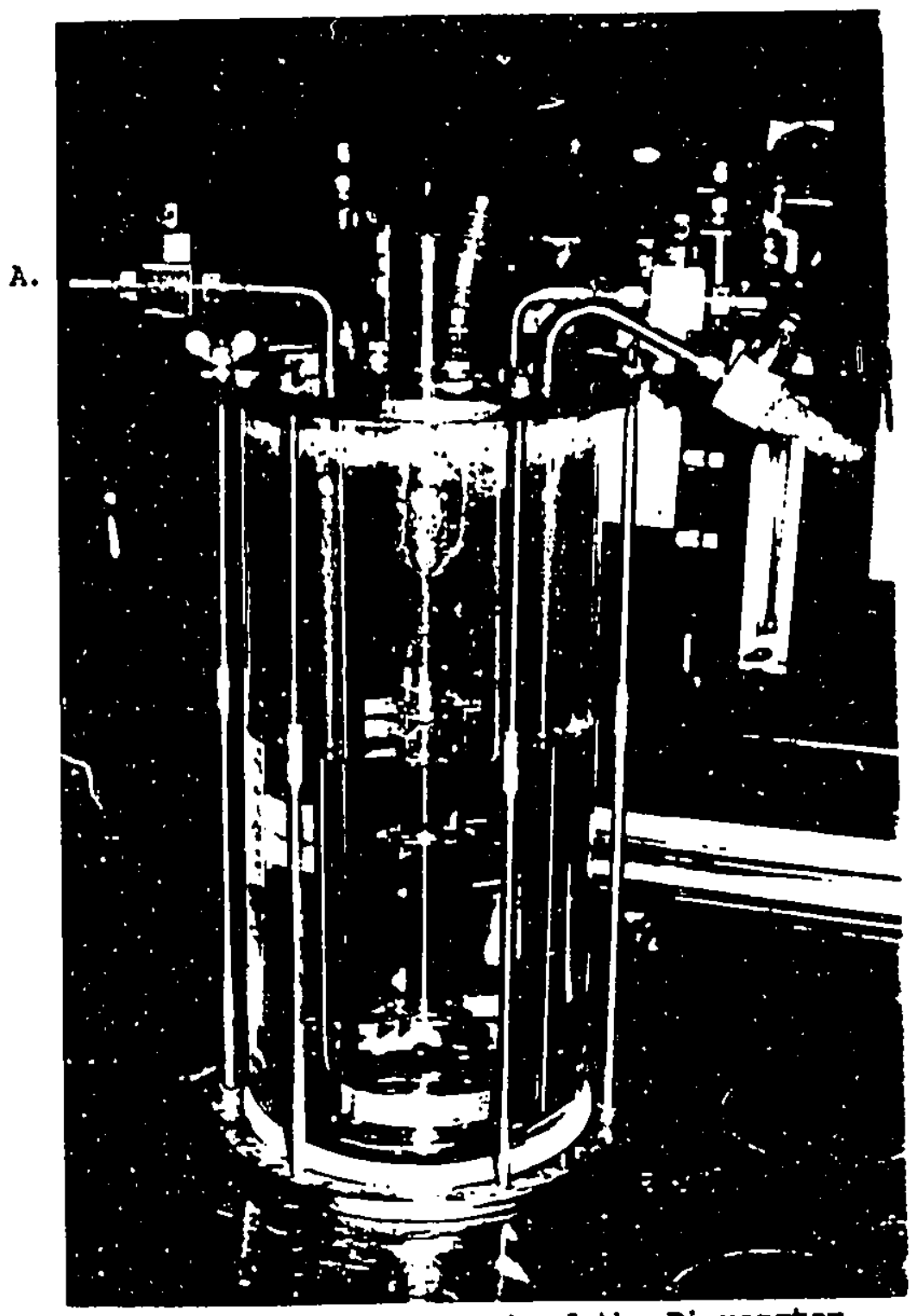

B.

c.

FIGURE 3.1 Photograph of the Bioreactor

Valves were added to the original

A. Sparger inlet,

B. Air inlet,

C. Bottom sampling tube 
(1988) was used for culture tubes and the experimental reactors because of its simpler composition.

The recipe for $8.5 \mathrm{~L}$ of medium was as follows:

\begin{tabular}{|c|c|}
\hline $\begin{array}{l}\mathrm{Na}_{2} \mathrm{EDTA} \cdot 2 \mathrm{H}_{2} \mathrm{O} \\
\mathrm{MgSO}_{4} \cdot 7 \mathrm{H}_{2} \mathrm{O} \\
\mathrm{CaCl}_{2} \cdot 2 \mathrm{H}_{2} \mathrm{O} \\
\mathrm{NaCl} \\
\mathrm{NH}_{4} \mathrm{Cl} \\
\mathrm{KH}_{2} \mathrm{PO} \\
\mathrm{TraCe} \text { Elements } \\
\mathrm{diH}_{2} \mathrm{O}\end{array}$ & $\begin{array}{l}0.11 \mathrm{~g} \\
1.80 \mathrm{~g} \\
0.45 \mathrm{~g} \\
3.60 \mathrm{~g} \\
3.60 \mathrm{~g} \\
4.5 \mathrm{~g} \\
9.0 \mathrm{~mL} \\
4.5 \mathrm{~L}\end{array}$ \\
\hline \multicolumn{2}{|l|}{ Blcarbonate } \\
\hline $\begin{array}{l}\mathrm{NaHOO}_{2} \\
\text { diHz } \\
\text { vitamin } \mathrm{B}_{12} \text { solution } \\
\qquad(24 \mu \mathrm{g} / \mathrm{mL})\end{array}$ & $\begin{array}{r}18.0 \mathrm{~g} \\
3.6 \mathrm{~L} \\
7.4 \mathrm{~mL}\end{array}$ \\
\hline \multicolumn{2}{|l|}{ Sulfide } \\
\hline $\begin{array}{l}\mathrm{NaOH} \\
\mathrm{Na}_{2} \mathrm{~S} \cdot 9 \mathrm{H}_{2} \mathrm{O} \\
\mathrm{dadi} \mathrm{H}_{2} \mathrm{O}\end{array}$ & $\begin{array}{l}\text { varies } \\
\text { varies } \\
0.9 \text { L }\end{array}$ \\
\hline
\end{tabular}

The mineral salt solution was autoclaved and cooled in a cold water bath. Carbon dioxide was bubbled through the bicarbonate solution for at least $k$ hour, after which the vitamin $B_{12}$ solution was added. Deaerated, distilled water vas added to an erlenmeyer flask containing sodium sulfide and sodium hydroxide and the flask was gently swirled. The bicarbonate and sulfide solutions were combined in a $5 \mathrm{~L}$ dispensing pressure vessel (Milipore Filter Corp.) and pressurized under $\infty_{2}$. The outlet liquid was forced through a $0.45 \mu \mathrm{m}$ pore, $47 \mathrm{~mm}$ diameter cellulose nitrate filter (Sartorius GmbH) held in a Gelman model 4280 filter holder directly into the sterile culture tube or reactor.

Carbon dioxide was not a limiting nutrient for bacterial growth (see 
Appendix C).

\subsubsection{Culture Tubes}

Culture tubes $(70 \mathrm{~mL})$ were half-filled with the mineral salts solution and autoclaved with the caps on loosely. The tubes were then taken into an Enviroco EV424 laminar flow hood (Biodynamics Inc.) and filled with the filter-sterilized bicarbonate/sulfide solution. The pH and sulfide content of the first and last tubes were checked. The pH was found to be in the prescrlbed range of 6.8 to 7.3 . The tubes were stored in a refrigerator until used.

\subsubsection{One Litre Reactor}

A 1 I round bottom flask was fitted with a stopper through which four glass tubes were inserted. The first tube was covered with a rubber septum. The second tube extended to $1 \mathrm{~cm}$ from the bottom of the flask and a sllicon rubber tube was attached. The third tube was the filling port for the round bottom flask and the other tube was stuffed with glass wool and used as a gas outlet while filling.

A magnetic stir bar was added to the flask, and all tubes were covered before autoclaving. The reactor was purged with $\infty_{2}$ for 5 minutes while cooling. The medium recipe was proportioned to $1.5 \mathrm{~L}$ volume. The mineral salts, bicarbonate and sulfide solutions were combined and filter -sterilized directly into the flask through the filling port. The flask was kept in a refrigerator for one day prlor to innoculation.

\subsubsection{Fifteen Litre Reactor}

The reactor was autoclaved and allowed to cool. Roughly $4.3 \mathrm{~L}$ of the sterile mineral salts solution was vacuumed into the reactor through the sparger inlet. The reactor purged through the sparger inlet with 
$\mathrm{CO}_{2}$ for 5 minutes after which the combined bicarbonate/sulfide solution was filter-sterilized into the reactor. The pre-innoculation fill volume was $8.5 \mathrm{I}$ for each reactor run where $1 \mathrm{~L}$ of bacteria medium was to be added. When the reactor was to be monitored as a control, $4.5 \mathrm{~L}$ of mineral salts and $4.5 \mathrm{~L}$ of bicarbonate/sulfide were added.

The reactor was kept covered at room temperature for 24 hours then placed in the fermentor drive assembly waterbath.

\subsection{Experimental Protocol}

\subsubsection{Innoculation and Incubation}

c. thiosulfatophilum was subcultured into Eresh culture medium on a weekly basis. About $2 \mathrm{~mL}$ of the sediments in the tube were pipetted into a sterile $70 \mathrm{~m}$ culture tube kept under nitrogen while open. A fresh culture tube was innoculated six to thirteen days before commencing the batch reactor test.

Four days (five in Run 7) before the start of the batch reactor test, the $1 \mathrm{~L}$ reactor were innoculated. The contents of two $70 \mathrm{~mL}$ culture tubes was transferred into four autoclaved $30 \mathrm{~mL}$ centrifuge tubes in a laminar flow hood. The tubes were covered with sterlle aluminum foll and centrifuged at $3000 \mathrm{rpm}$ for 30 minutes. The tubes were returned to the laminar flow hood and the supernatant was pipetted and discarded. The remaining $k \mathrm{~mL}$ of the supernatant in each tube was used to resuspend the pellet by swirling. The resuspended pellets were drawn into a sterile 5 $\mathrm{mL}$ glass syringe (Becton Dickinson) to a total volune of $2 \mathrm{~mL}$. The $1 \mathrm{~L}$ flask was placed in a water bath (model 3067 , Labline Inc.) at $30^{\circ} \mathrm{C}$ wille stirred and illuminated by a General Electric 250 att reflector infrared bulb $150 \mathrm{~mm}$ from the flask. The contents of the syringe were injected 
into the $1 \mathrm{~L}$ flask through the septum while the gas outlet was open. Then all tubes were clamped shut.

The $\mathrm{pH}$ and sulfide content of the $15 \mathrm{~L}$ reactor were monitored prior to innoculation. The pH was adjusted to the range 6.9 to 7.2 by the injection of sterile $1 \mathrm{M} \mathrm{NaOH}$ solution through the septum. The tube leading to the bottom of the $1 \mathrm{~L}$ flask was connected to the bottom sampling tube. Nitrogen gas pressure was introduced into the gas outlet port of the $1 \mathrm{~L}$ flask forcing the four-day-old bacteria culture into the reactor. The liquid volume in the $15 \mathrm{~L}$ reactor was 9.0 to $9.7 \mathrm{~L}$. No innoculation was made to the reactor run as a control.

\subsubsection{Batch Reactor Tests}

After innoculation, no effort was made to alter the $\mathrm{pH}$ and sulfide values. The initial values of $\mathrm{pH}$ and concentration of sulfide are shown in Table 3.I for the seven runs.

Draws were made immediately after innoculation (time $=0 \mathrm{~h}$ ) and periodically thereafter. The typical interval between draws was 3 hours. A draw consisted of pressurizing the reactor with nitrogen gas to 20 to 30 $\mathrm{kPa}$ ( 3 to $4 \mathrm{psig}$ ), then opening the bottom sampling tube valve. The first 25 to $35 \mathrm{~mL}$ of the draw were discarded so as not to sample from the stagnant volume inside the bottom sampling tube. From the rest of the draw, a sample was taken immediately for sulfide analysis. Other samples for sulfur, sulfate, bchl and $\mathrm{pH}$ were taken thereafter. The time when the sample was added to reagents was recorded and considered to be the time when the reaction had stopped. The measurement of the parameter was considered to be taken at this time.

When the reactor was used for control Run 3, the $\mathrm{pH}$ was adjusted by 
TABLE 3.1 Initial Values of $\mathrm{pH}$ and Sulfide Concentration

\begin{tabular}{|c|c|c|c|}
\hline & Run & & $\begin{array}{l}\left(\mathrm{s}^{2}-\mathrm{lo}_{0}\right. \\
(\mathrm{mg} / \mathrm{\omega})\end{array}$ \\
\hline \multirow[t]{2}{*}{$\begin{array}{l}\text { Batch } \\
\text { Reactor }\end{array}$} & $\begin{array}{c}1 \\
1 \text { control } \\
2 \\
3 \\
3 \text { control } \\
4 \\
5 \\
6 \\
7\end{array}$ & $\begin{array}{l}6.90 \\
6.50 \\
6.96 \\
7.27 \\
7.36 \\
7.01 \\
7.04 \\
7.32 \\
7.46\end{array}$ & $\begin{array}{r}72.2 \pm 4.4 \\
65.8 \pm 4.4 \\
88.1 \pm 5.5 \\
120 . \pm 5.5 \\
123 . \pm 5.5 \\
453 . \pm 22 \\
271 . \pm 22 \\
23.7 \pm 2.9 \\
73.2 \pm 3.1\end{array}$ \\
\hline & Injection & & \\
\hline $\begin{array}{l}\text { Semi- } \\
\text { Batch } \\
\text { Reactor }\end{array}$ & $\begin{array}{c}\text { initial } \\
1 \\
2 \\
3 \\
4\end{array}$ & $\begin{array}{l}6.88 \\
7.35 \\
7.48 \\
6.45 \\
7.22\end{array}$ & $\begin{array}{r}94.3 \pm 5.5 \\
156 . \pm 5.5 \\
133 . \pm 5.5 \\
112 . \pm 5.5 \\
120 . \pm 5.5\end{array}$ \\
\hline
\end{tabular}


injecting sterile $1 \mathrm{M}$ NaOH solution. The sulfide content was lowered by pressurlzing the reactor headspace with nitrogen to 20 to $30 \mathrm{kPa}$ ( 3 to 4 psig) and subsequently venting the headspace through the gas inlet port. Ten repetitions of this venting procedure, while stirring at $3000 \mathrm{rpm}$ reduced the sulfide concentration by 5 to $20 \mathrm{mg} / \mathrm{L}$. The control for Run 3 was performed after Run 3 and thus the timing and volume of the draws were made to minic those of Run 3. The control for Run 1 performed before Run 1.

\subsubsection{Sen-Batch Reactor Test}

In this experiment, the initial consumption of sulfide was monitored as explained in section 3.3.2. After the sulfide was depleted, 1 L of sulfide solution was filter-sterilized and pressurized into the reactor. The sulfide solution was made from washed, drled $\mathrm{Na}_{2} \mathrm{~S} \cdot 9 \mathrm{H}_{2} \mathrm{O}$ crystals dissolved in dadiH ${ }_{2} \mathrm{O}$. After monitoring depletion of the sulfide, another $1 \mathrm{~L}$ of sulfide solution was injected. Altogether there were four infections of sulfide solution. Prior to the third injection, the pH was adjusted with $1 \mathrm{M} \mathrm{NaOH}$. The values of initial $\mathrm{pH}$ and sulfide concentration are given in Table 3.1.

\subsubsection{Calculations}

For each experimental run or injection, the values for bchl concentration were plotted against time on semi-log paper. The exponential growth phase was determined from this plot and the specific growth rate was calculated by a modifled form of Equation 2.10:

$$
\text { H }=2.303\left[\frac{\log [\mathrm{bch} 1]_{\xi_{2}}-\log [\mathrm{bch} 1]_{t_{2}}}{t_{2}-t_{1}}\right]
$$

The values of $\mu$ for all runs and infections were plotted against the 
substrate (sulfide) concentration at the begining of the log-growth phase.

The Haldane Equation 2.12 was fitted to this data using the curve fitting function of the computer program sigma-plot Version 4.0 (Jandel Scientific, Sausalito, CA).

True cell yield was calculated also during the log-growth phase. since bchl used as an Indlcator of blomass and sulfide was the substrate, the cell yield (Equation 2.13) was modifled to:

$$
Y_{t}^{*}=\frac{[b c h l]_{c_{2}}-[b c h l]_{c_{2}}}{\left[\mathbf{s}^{2-}\right]_{c_{2}}-\left[\mathbf{s}^{2-}\right]_{c_{1}}}
$$

where $y t *=$ truc cell yield based on bchl

$\left[\mathrm{s}^{\mathrm{a}}-\mathbf{]}=\right.$ sulfide concentration at $\mathrm{time} t(\mathrm{mg} / \mathrm{L})$

A sulfur balance was performed by plotting the values of concentrations of sulfur species in a stacked bar graph. Where necessary, the data were interpolated linearly to produce even time intervals. The cumulative uncertainty of all sulfur species concentrations are plotted as an error bar on the graph.

Sulfur recovery was calculated for each run as follows:

$$
8 \text { Recovery }=100 \frac{\left[8^{\circ}\right]_{\mathrm{mx}_{x}}-\left[8^{0}\right]_{1}}{\left[8^{2-}\right]_{1}-\left[8^{2-}\right]_{1}}
$$

where $\left[S^{\circ}\right]_{\text {e }}=$ maximm elemental sulfur concentration for the run $(\mathrm{mg} / \mathrm{L})$

$\left[\mathbf{8}^{2-}\right]_{2}=$ initial measured sulfide concentration

$\left[8^{\circ}\right]_{2}=$ elemental sulfur concentration at the time of the initial sulfide measurement $(\mathrm{mg} / \mathrm{L})$

$\left[\mathrm{g}^{2-}\right]_{-}=$sulfide reading colncident with $\left[\mathrm{S}^{0}\right]_{\max }(\mathrm{mg} / \mathrm{L})$ 
The specific sulfide utilization rate was obtained by calculating the slope of the $\left[\mathrm{S}^{2-}\right]$ versus time curve between measured data points and dividing by the concentration of bchl interpolated at the midpoint of the time interval:

$$
0=\frac{\left[8^{2-}\right] t_{1}-\left[8^{2-}\right] t_{2}}{\left(t_{2}-t_{2}\right)[\mathrm{bch} 1]_{t_{1.0}}}
$$

$$
\text { where } \begin{aligned}
{\left[\mathrm{g}^{2-}\right]_{t}=} & \text { sulfide concentration at time=t }(\mathrm{mg} / \mathrm{L}) \\
\text { [bchl }]_{t=2.8}= & \text { bchl concentration at a time midway between } \\
& t_{2} \text { and } t_{2}(\mathrm{mg} / \mathrm{L})
\end{aligned}
$$


CHPLIR FOUR

RESTETS AD DIsaussian

\subsection{Batch Reactor Tests}

\subsubsection{Data}

Figures 4.1 to 4.14 display the data collected in batch reactor runs 1 through 7. Odd numbered flgures show the concentrations of sulfur species in the reactor and the concentration of bacterlochlorophyll (bchl) as functions of time. Where error bars are not shown, the data point symbol is larger than the errox bars. Even numbered figures display the reactor environmental conditions (pH, temperature, reactor liquid volume, reactor headspace) as functions of time.

Data points are Joined by straight lines with the exceptions of bchl in Run 7 and reactor volumes. The reading of bchl at 6 hour in Run 7 Indlcates a decrease in bchl concentration between 6 and 8 hours even though sulfide concentration is non-limiting at that time. Therefore, the 6 hour data point was Ignored and a second order regression was employed to Join the remaining points. In the plots of reactor environmental conditions, liquid volume and headspace volume data points were jolned with a step function corresponding to each withdrawl of I1quid.

In general, it can be seen that sulfide depletion is colncident with an increase in elemental sulfur concentration. Sulfate concentration typically does not increase until sulfide is depleted. Bacterlochlorophyll increases the fastest when sulfide is being consumed and continues until elemental sulfur is depleted.

In the control for Runs 1 and 3, it was observed that sulfide 

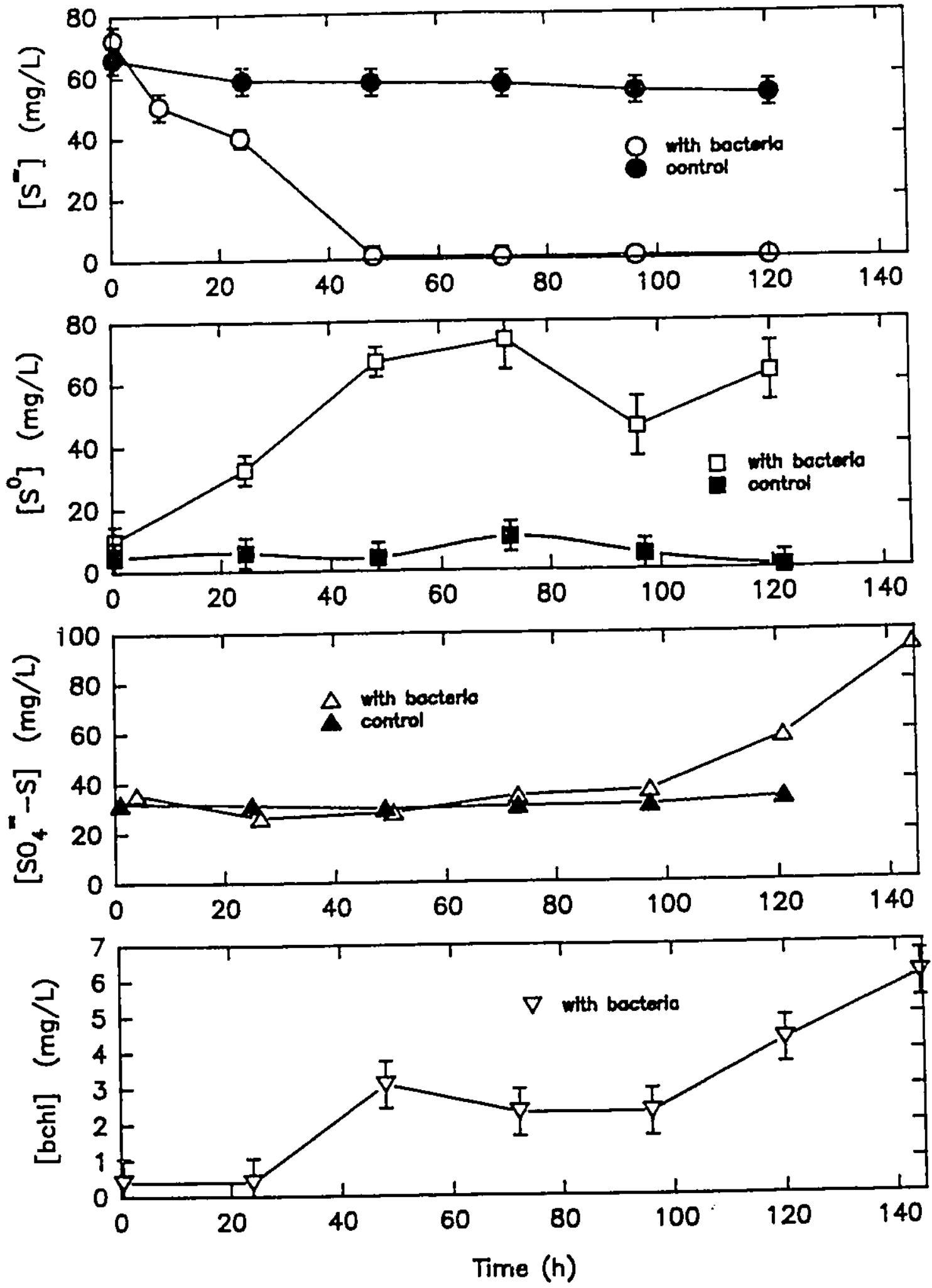

FIGURE 4.1 Concentrations in Batch Reactor Run 1 

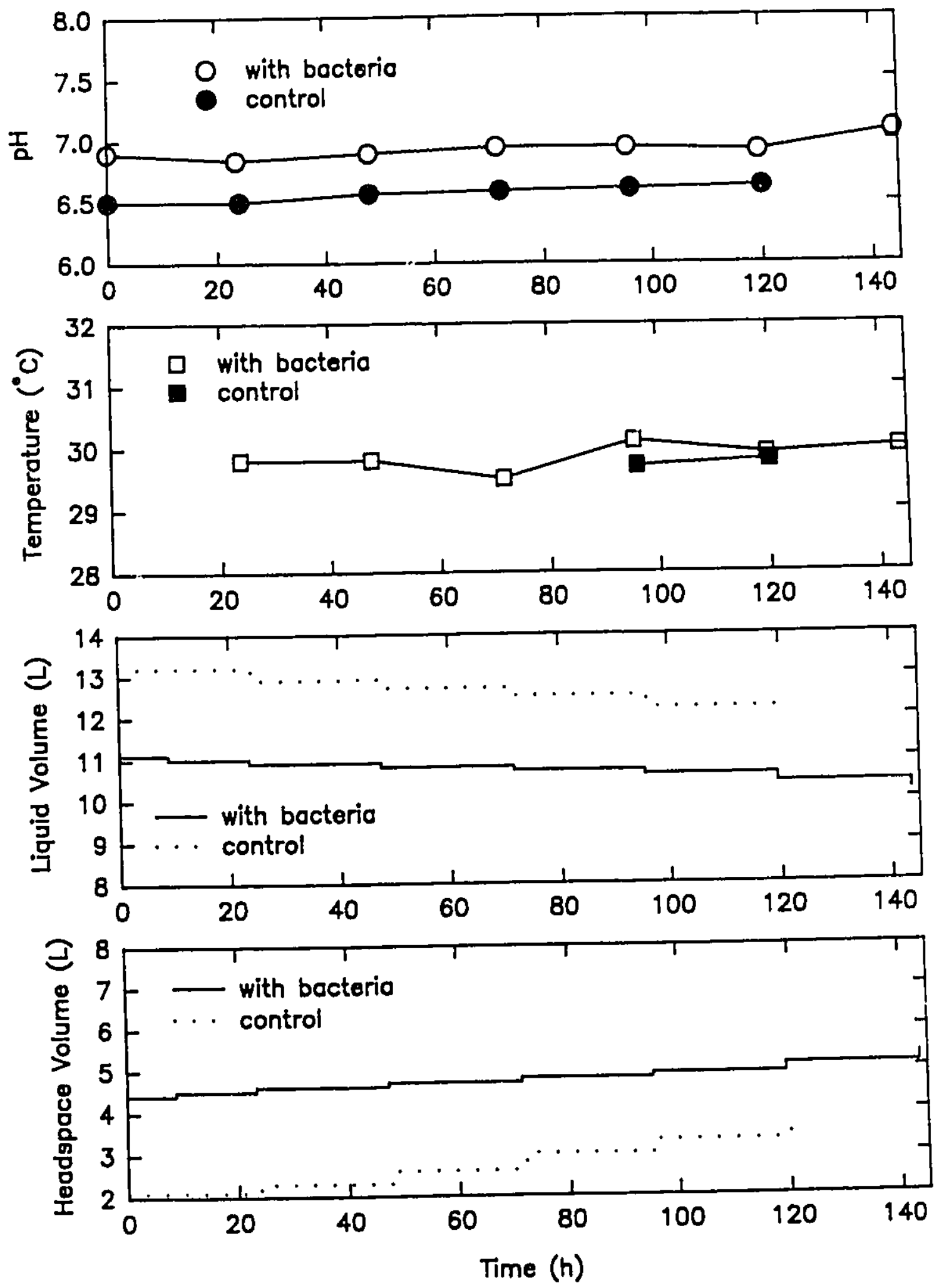

FIGURE 4.2 Reactor Environment for Batch Reactor Run 1 

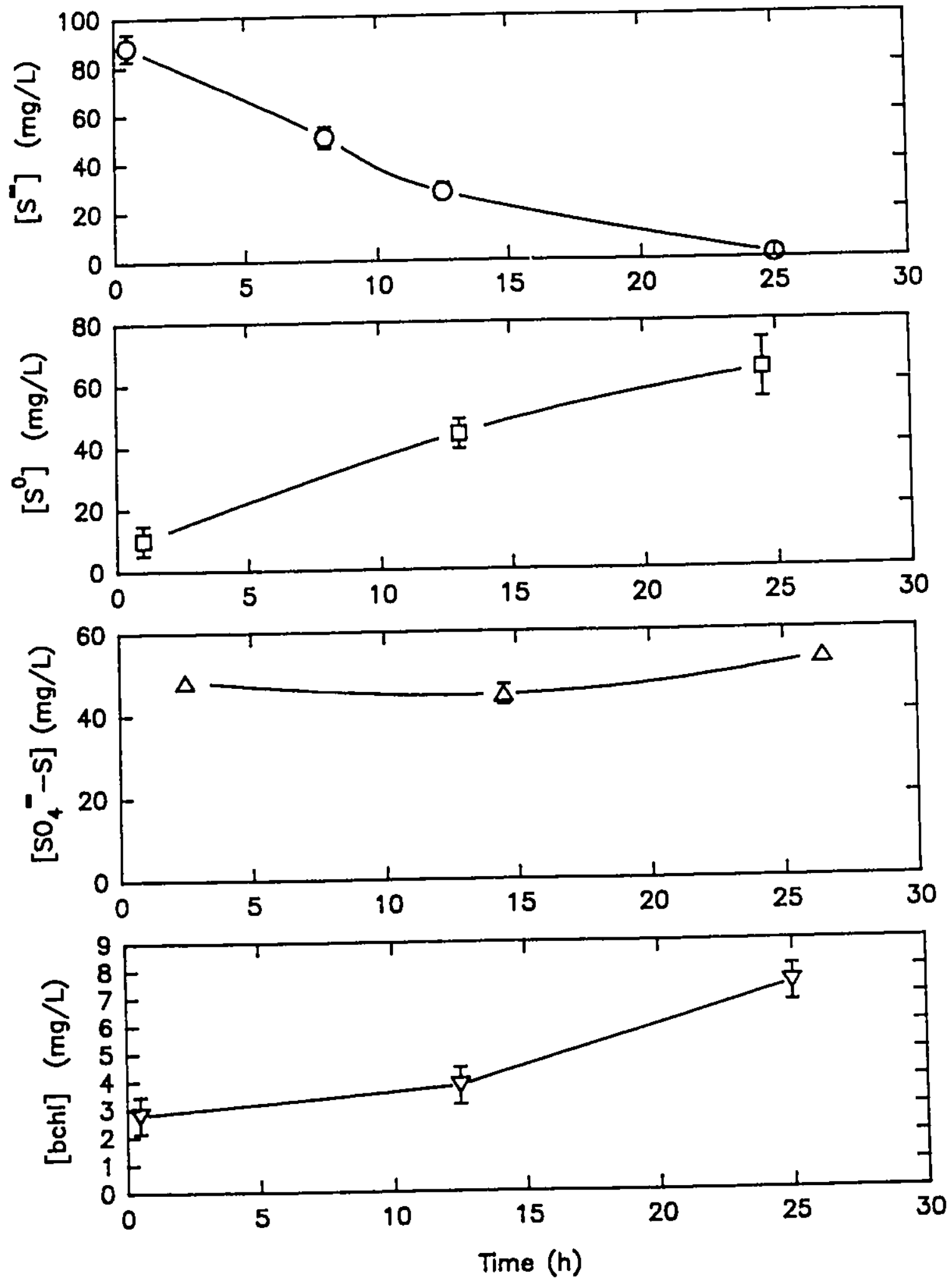

FIGURE 4.3 Concentrations in Batch Reactor Run 2 

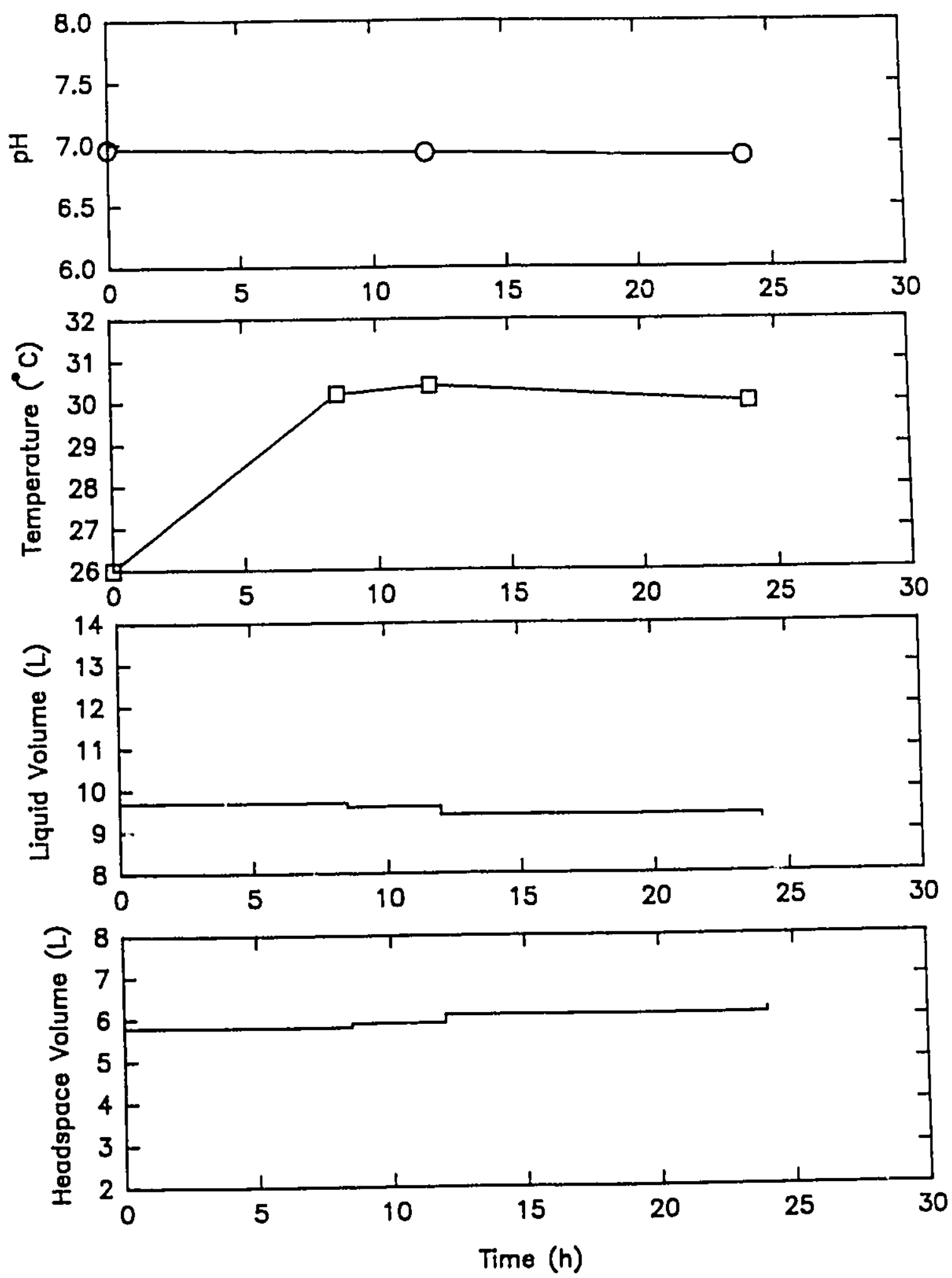

FIGURE 4.4 Reactor Environment for Batch Reactor Run 2 

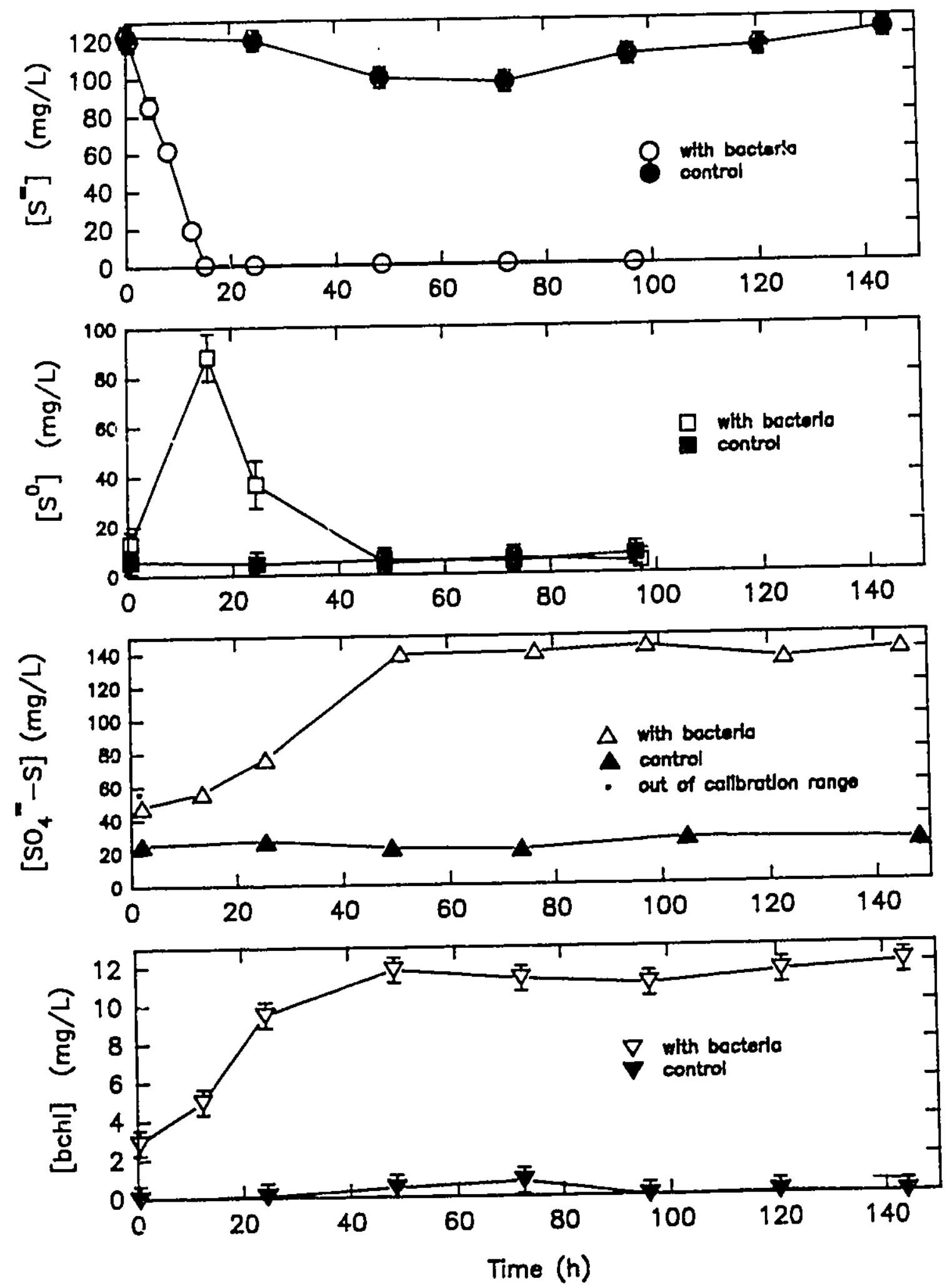

FIGURE 4.5 Concentrations in Batch Reactor Run 3 

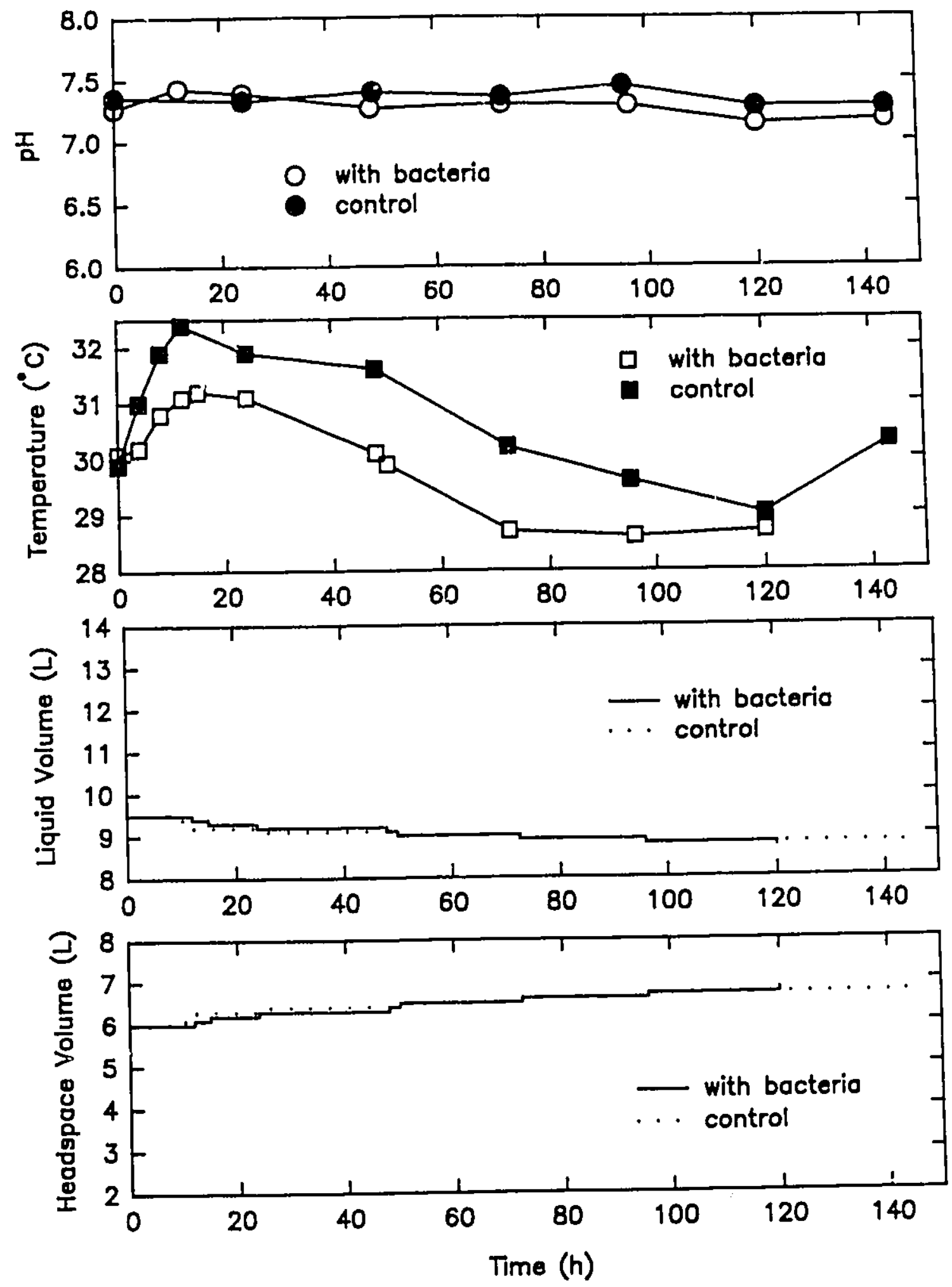

FIGURE 4.6 Reactor Environment for Batch Reactor Run 3 

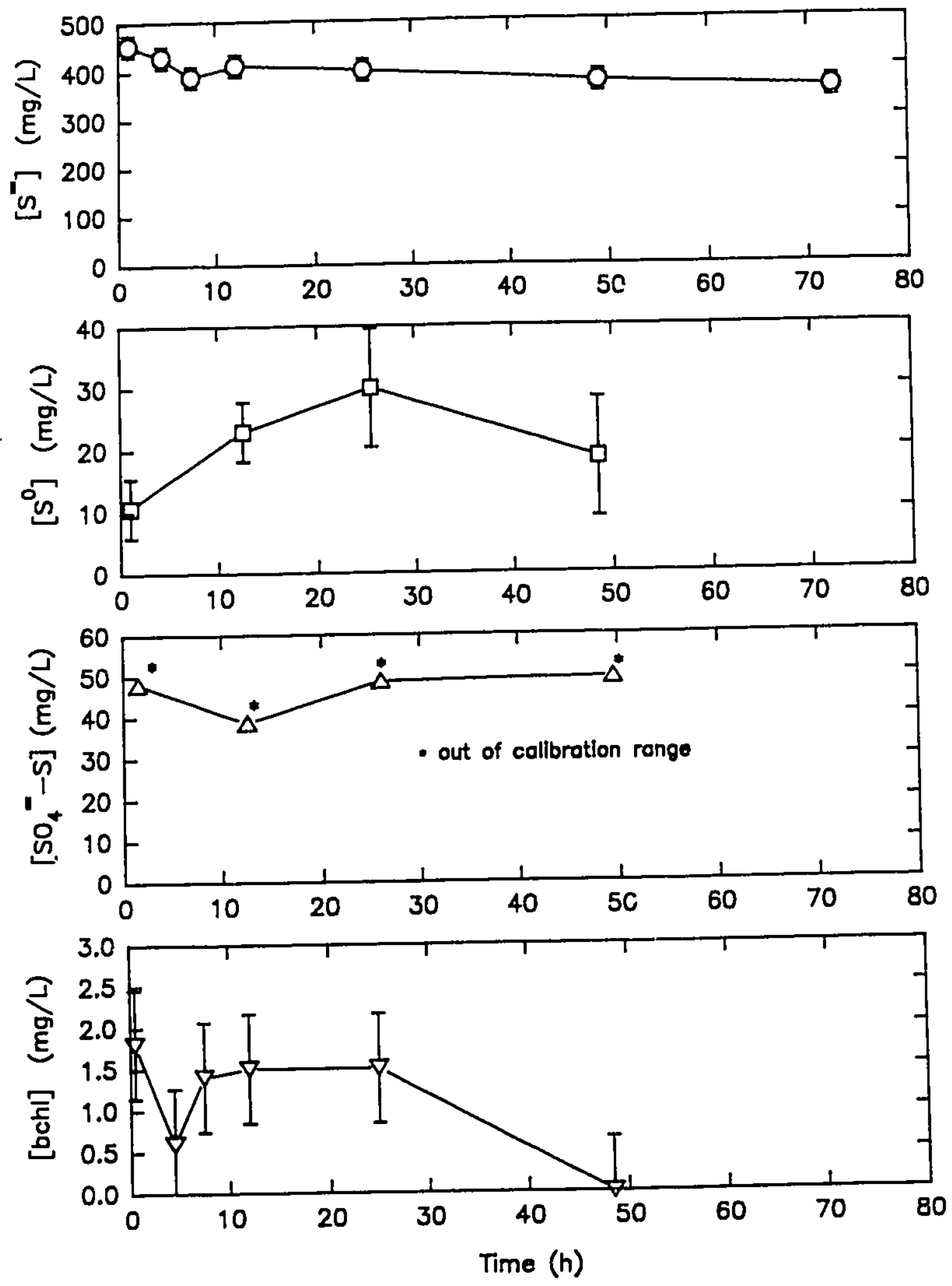

FIGURE 4.7 Concentrations in Batch Reactor Run 4 

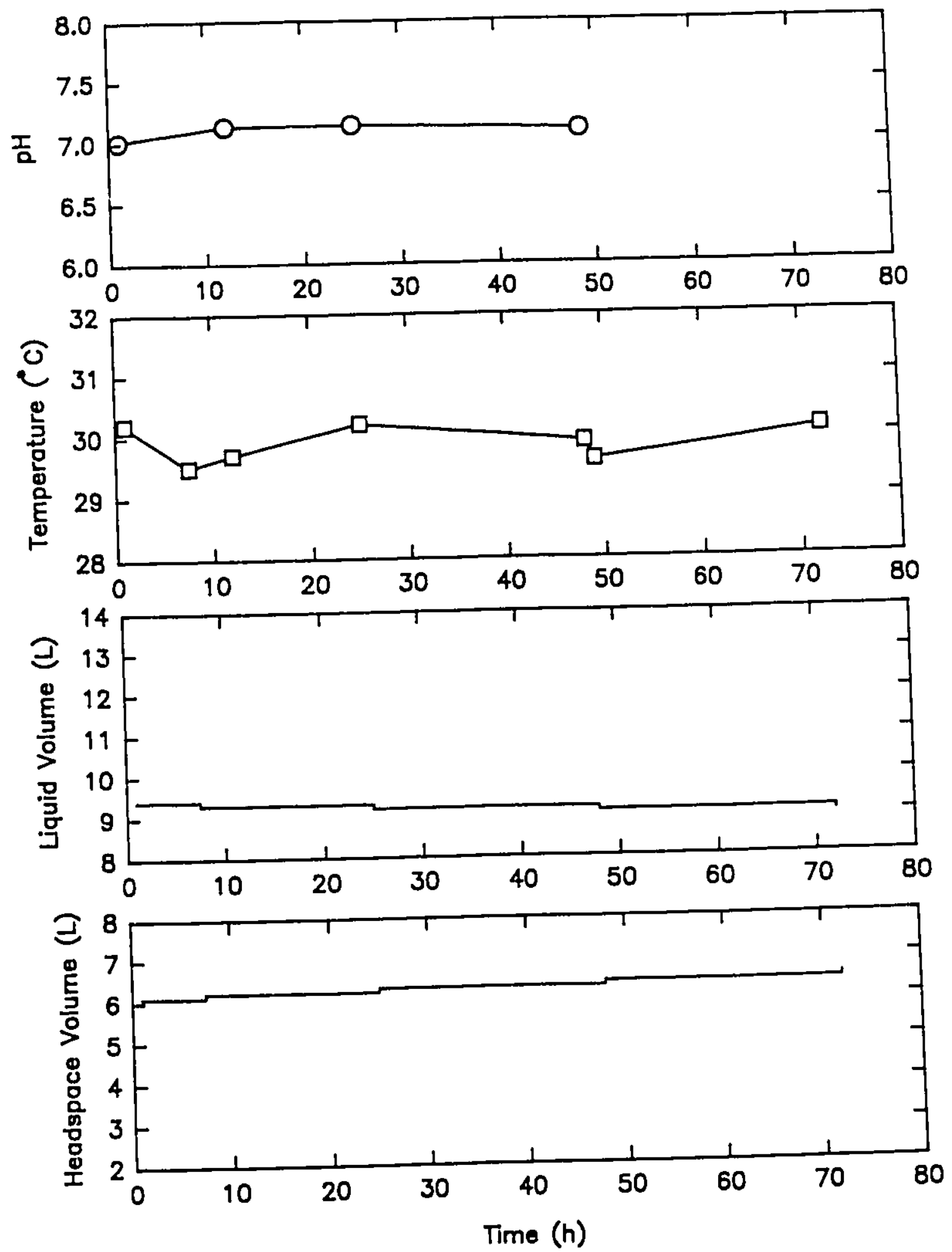

FIGURE 4.8 Reactor Environment for Batch Reoctor Run 4 

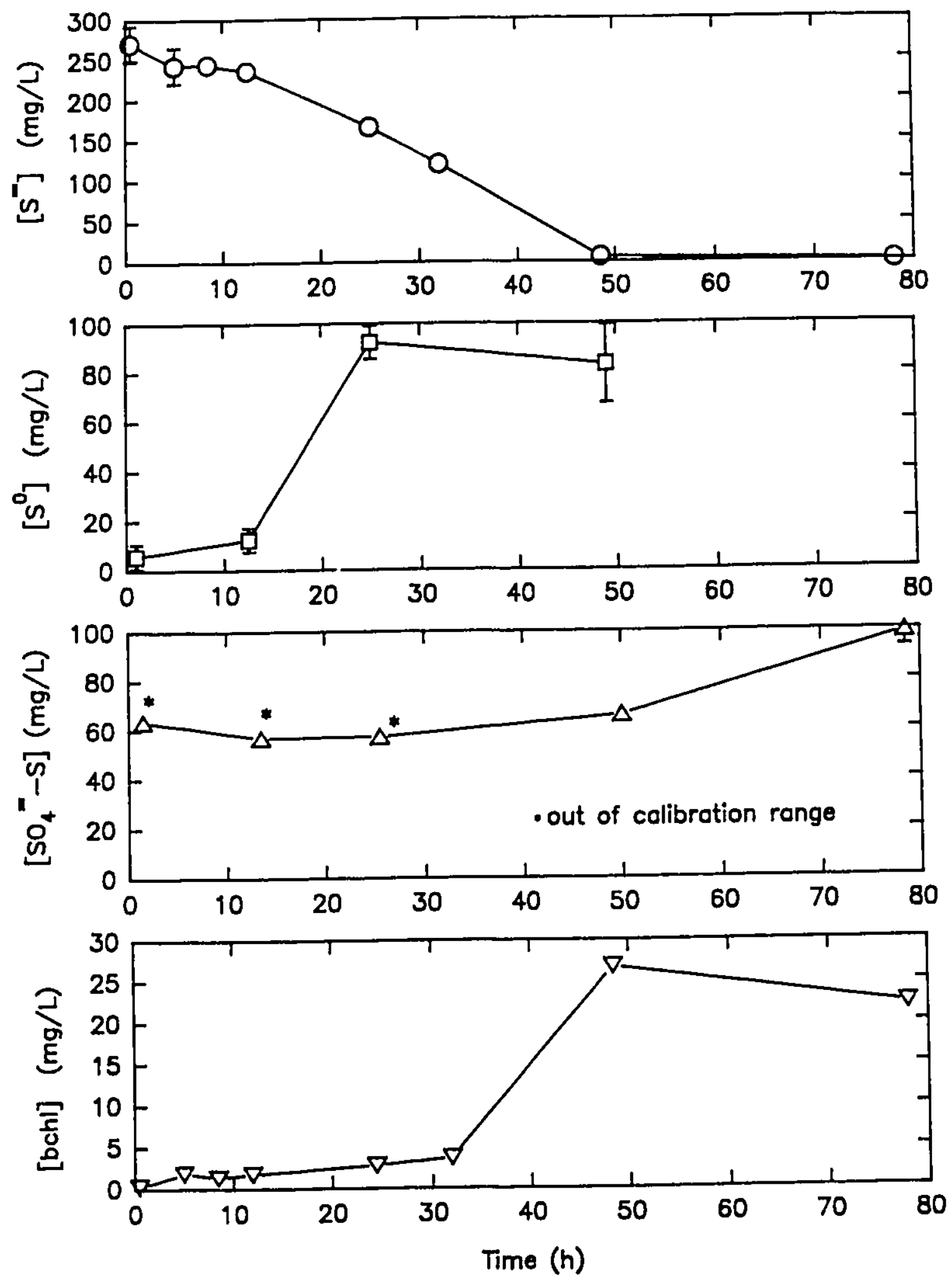

FIGURE 4.9 Concentrations in Batch Reactor Run 5 

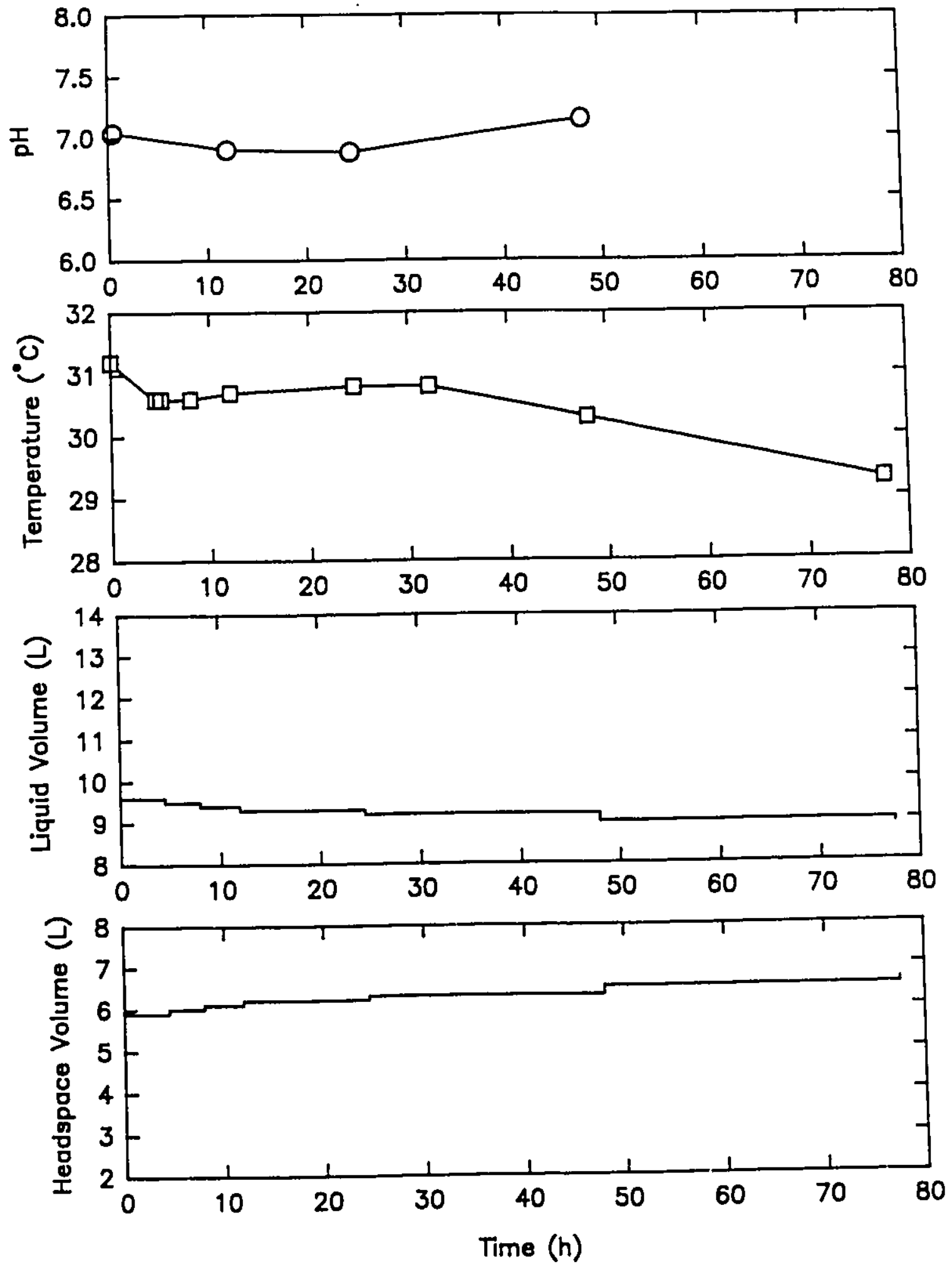

FIGURE 4.10 Reactor Environment for Batch Reoctor Run 5 

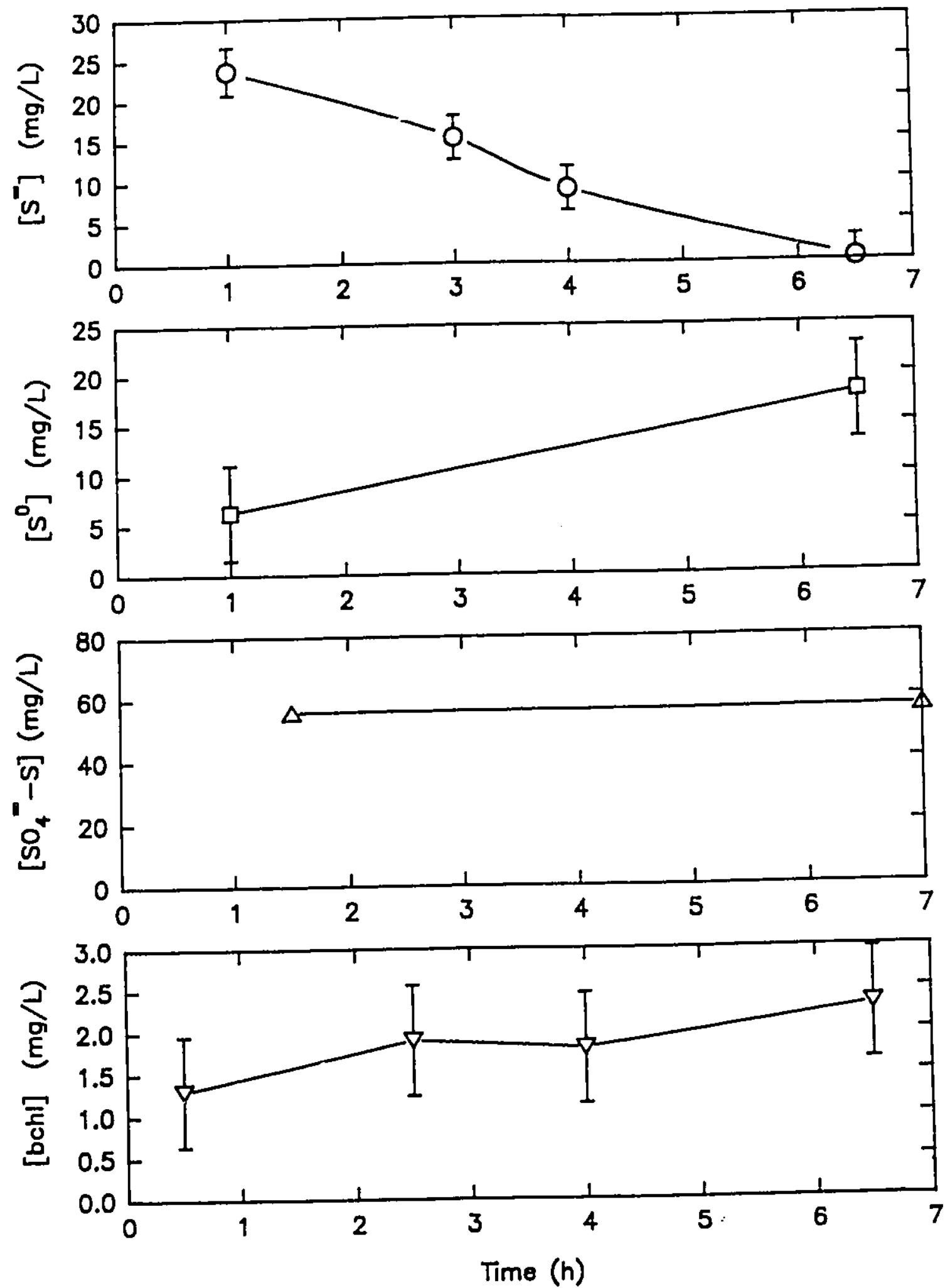

FIGURE 4.11 Concentrations in Batch Reactor Run 6 

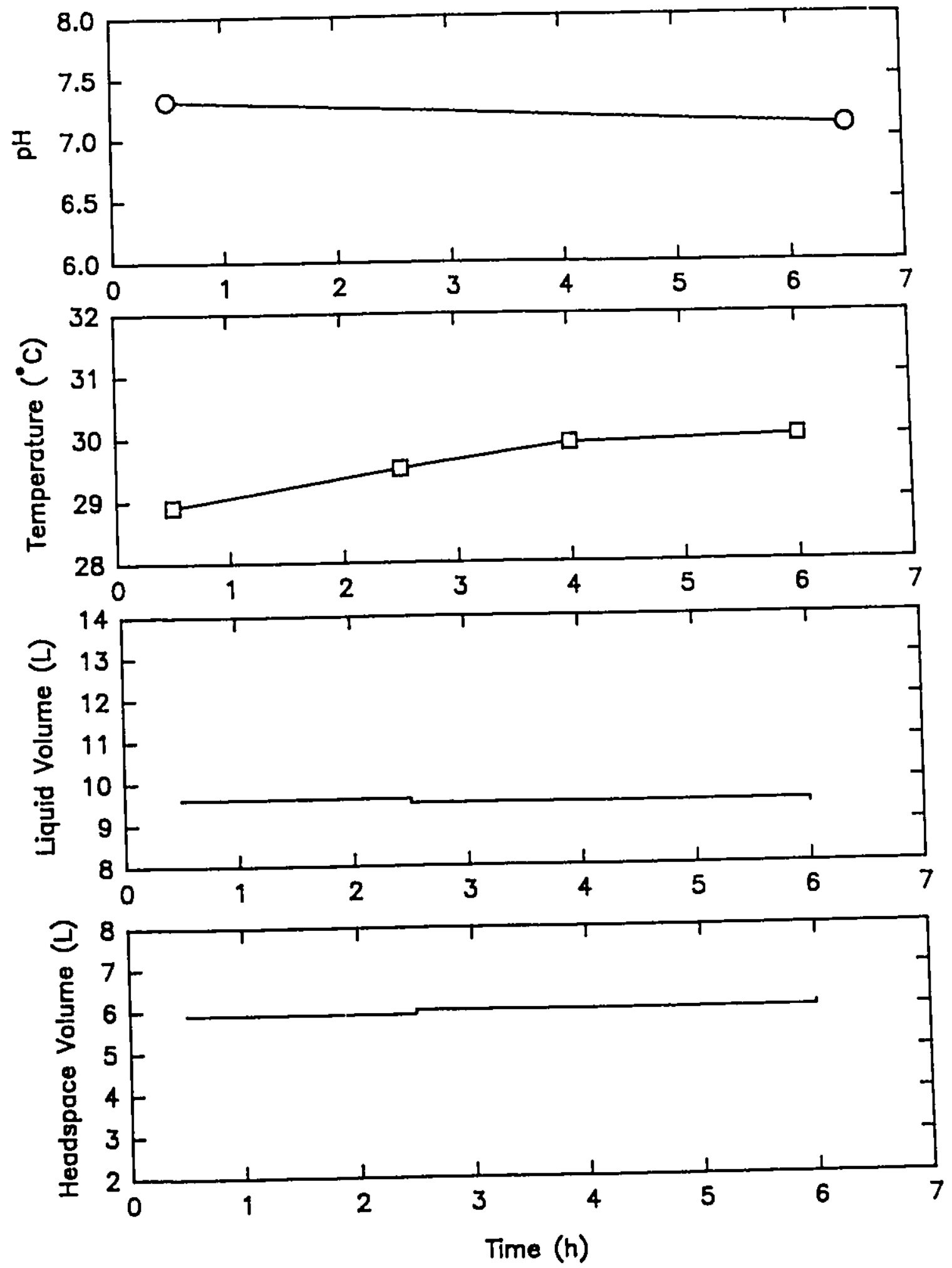

FIGURE 4.12 Reactor Environment for Batch Reactor Run 6 

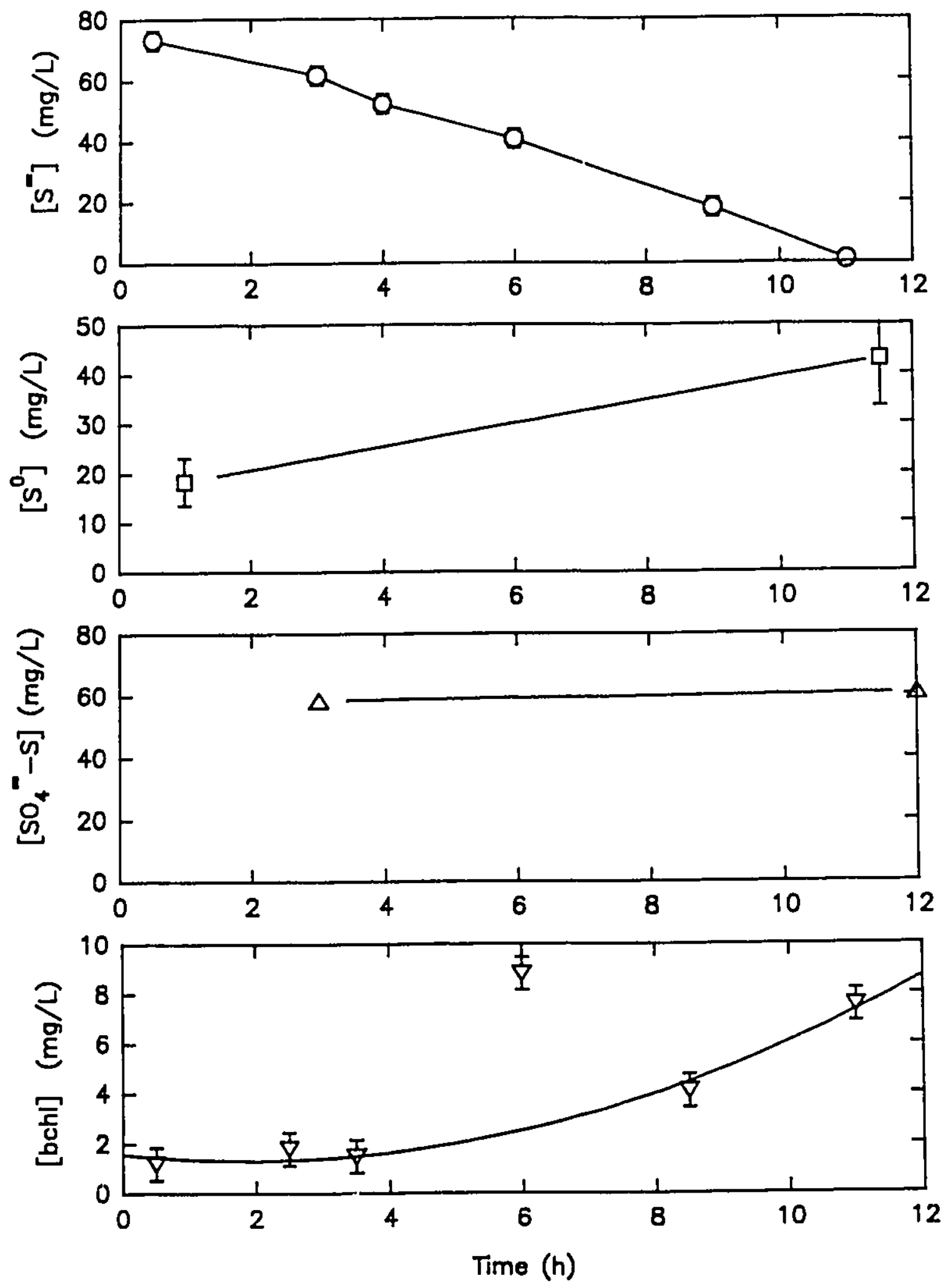

FIGURE 4.13 Concentrations in Batch Reactor Run 7 

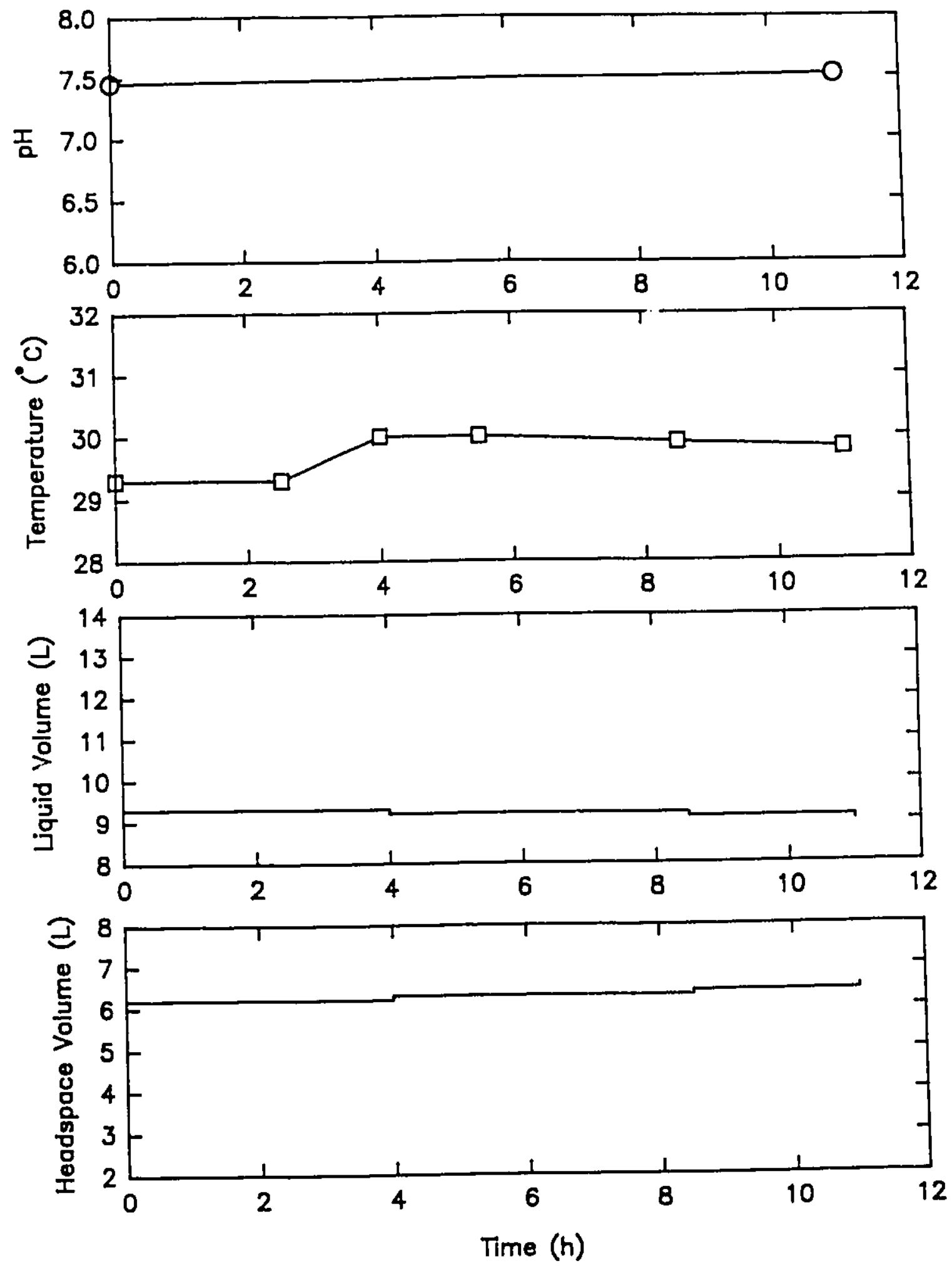

FIGURE 4.14 Reactor Environment for Batch Reactor Run 7 
concentration decreases moderately, either by reacting with oxygen remaining in the reactor or by leakage. Sulfate, elemental sulfur and bchl concentrations do not increase. Sulfate is initlally present in the reactor from the dissolved mineral salts.

\subsubsection{Growth of Bacteria}

The calculations for the specific growth rate $(\mu)$ are summarized in Table 4.1. For Run 4, there was a decay of bacteria from the initial concentration to zero because of the inhibitory effect of high sulfide concentration $(457 \mathrm{mg} / \mathrm{L})$. For this reason, Run 4 data are not used in the calculation of percent recovery of sulfur, sulfur balance, cell yield or sulfide utilization. Due to the sparsity of data, the steepest section of the [bchl] vs. time plot was considered to be the log growth phase even though as few as two points may have been used to calculate $\mu$. The slope of the $\log [$ bchl] versus time plot was determined by linear regression where more than two points were deemed to be in the log growth phase. When the measurement of bchl and sulfide were not coincident, the sulfide value was interpolated or extrapolated to the time of the bchl measurement. The possible errors in the $\mu$ values were calculated by adding or subtracting the uncertalnty in the bchl analysis to the measured bchl values before taking logarthms. The average deviations of these "worst case" slopes from the stated $\mu$ values were used as the uncertainty in the specific growth rate.

The values of specific growth rate are plotted against the sulfide concentration at the begining of the log-growth phase later in Figure 4.26. 


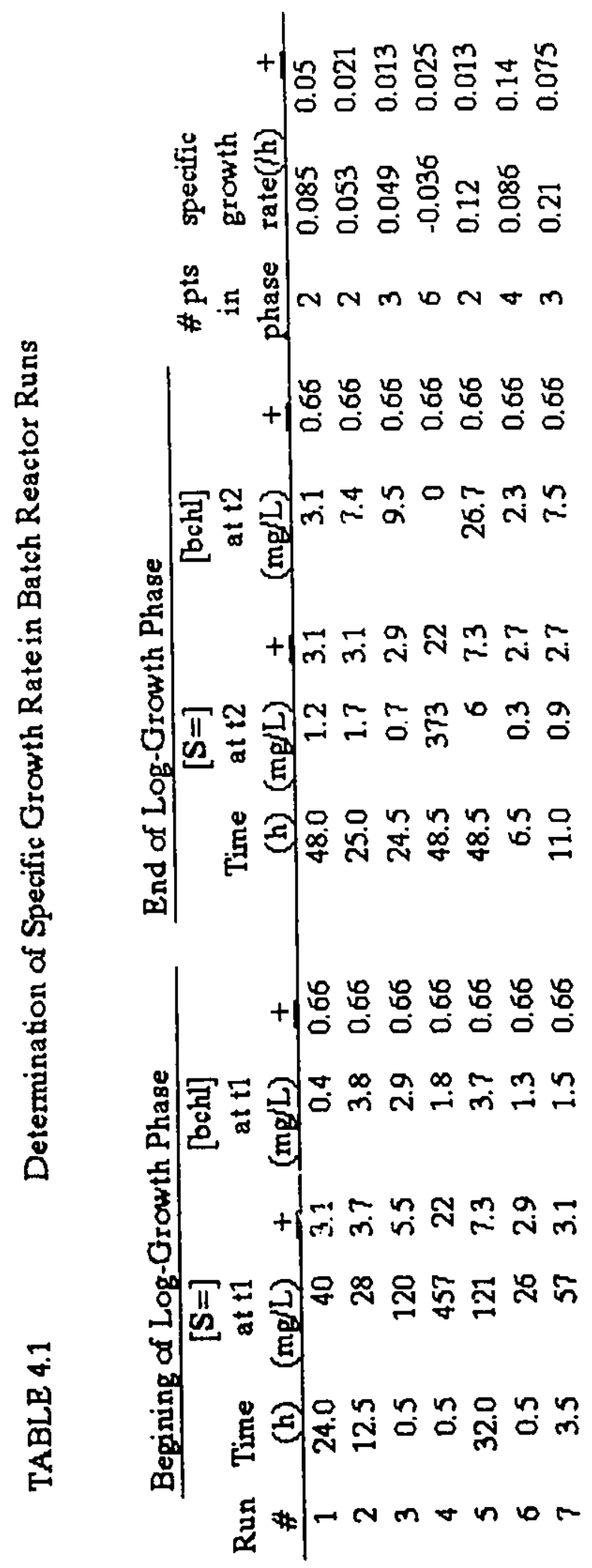




\subsubsection{Sulfur Balance and Recovery}

Stacked bar charts showing the concentrations of different sulfur specles with time are shown in Figures 4.15 to 4.22 . The error bars represent the cumblative uncertainties from the analyses of sulfide, elemental sulfur and sulfate. In non-control runs, the increase in $s^{\circ}$ did not fully compensate for the net decrease in sulfide. However, as elemental sulfur was depleted, sulfate concentration had increased. The rate of decrease in $\mathrm{S}^{\circ}$ was greater than the rate of increase in $\mathrm{SO}_{4}{ }^{2-}$ so that there was a depression in the cumulative measured sulfur concentrations (see Figures 4.15, 4.18). Cork (1978) observed that the concentrations of $S^{\circ}$ and sulfate did not equal the total concentration of sulfide oxidized by the iacteria. Further studies indicated that thiosulfate the intermediate form in wich sulfur was being accumulated. Thus, in Runs 1 and 3, the "rebound" of total sulfur may have been due to the accumulation and eventual oxidation of thiosulfate, which was not measured in these experiments.

In Runs 2, 5, 6 and 7, the sulfate concentration stayed constant as sulfide was converted to elemental sulfur. These experiments were ended when sulfide was depleted. A sulfur balance was not performed on Run 4 data as there was no elemental sulfur produced in this run.

Table 4.2 shows that 35 to $90 \%$ of the sulfide oxidized was converted to elemental sulfur. When the elemental sulfur concentration measurement was not coincident with the initial sulfide measurement, the $S^{\circ}$ data were extrapolated. Again, when sulfide was not determined at the same time as the highest measured $S^{\circ}$ concentration, the sulfide data were interpolated or extrapolated. In this way, the interpolation or extrapolation was 


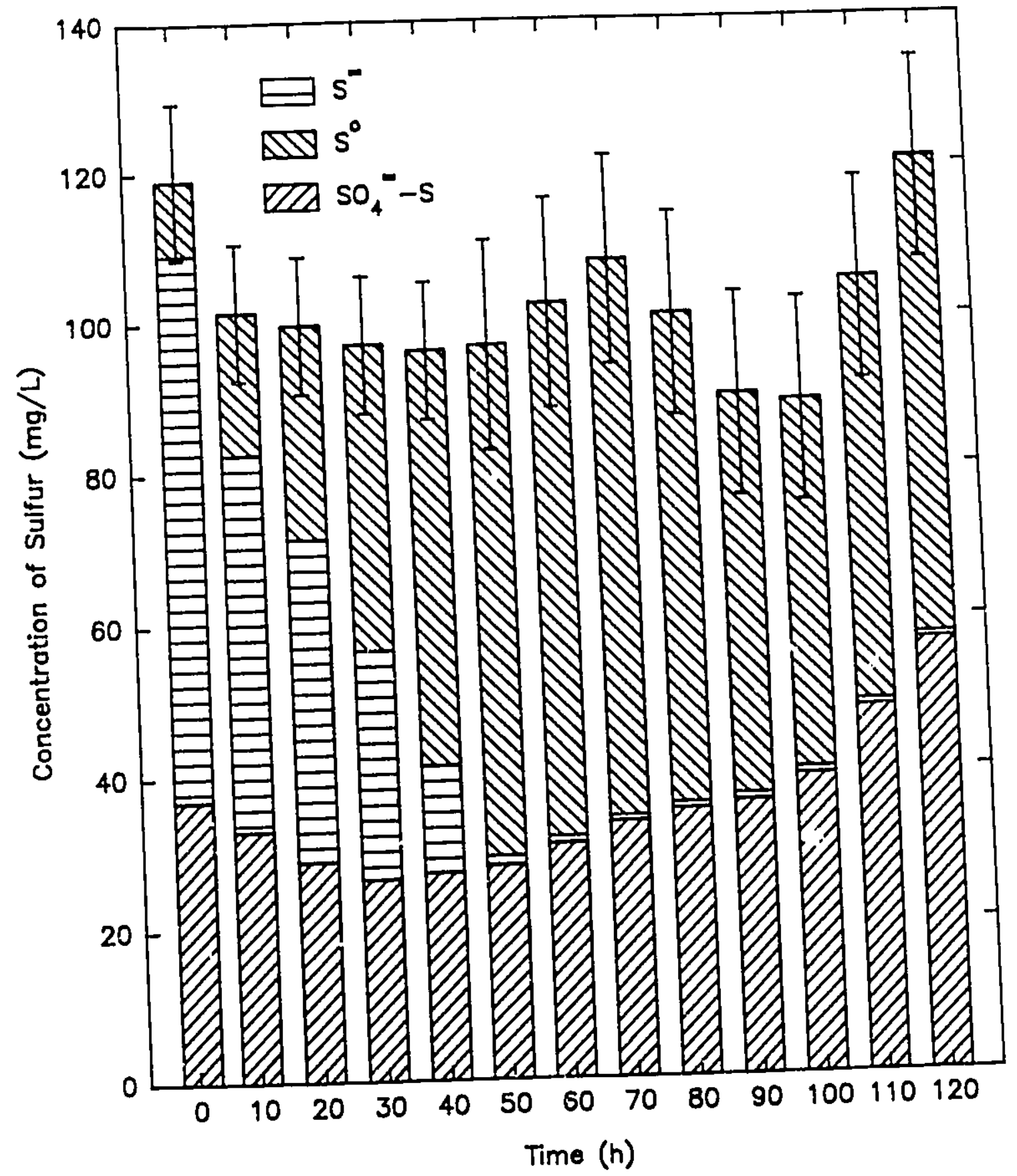

FIGURE 4.15 Sulfur Balance for Batch Reactor Run 1 


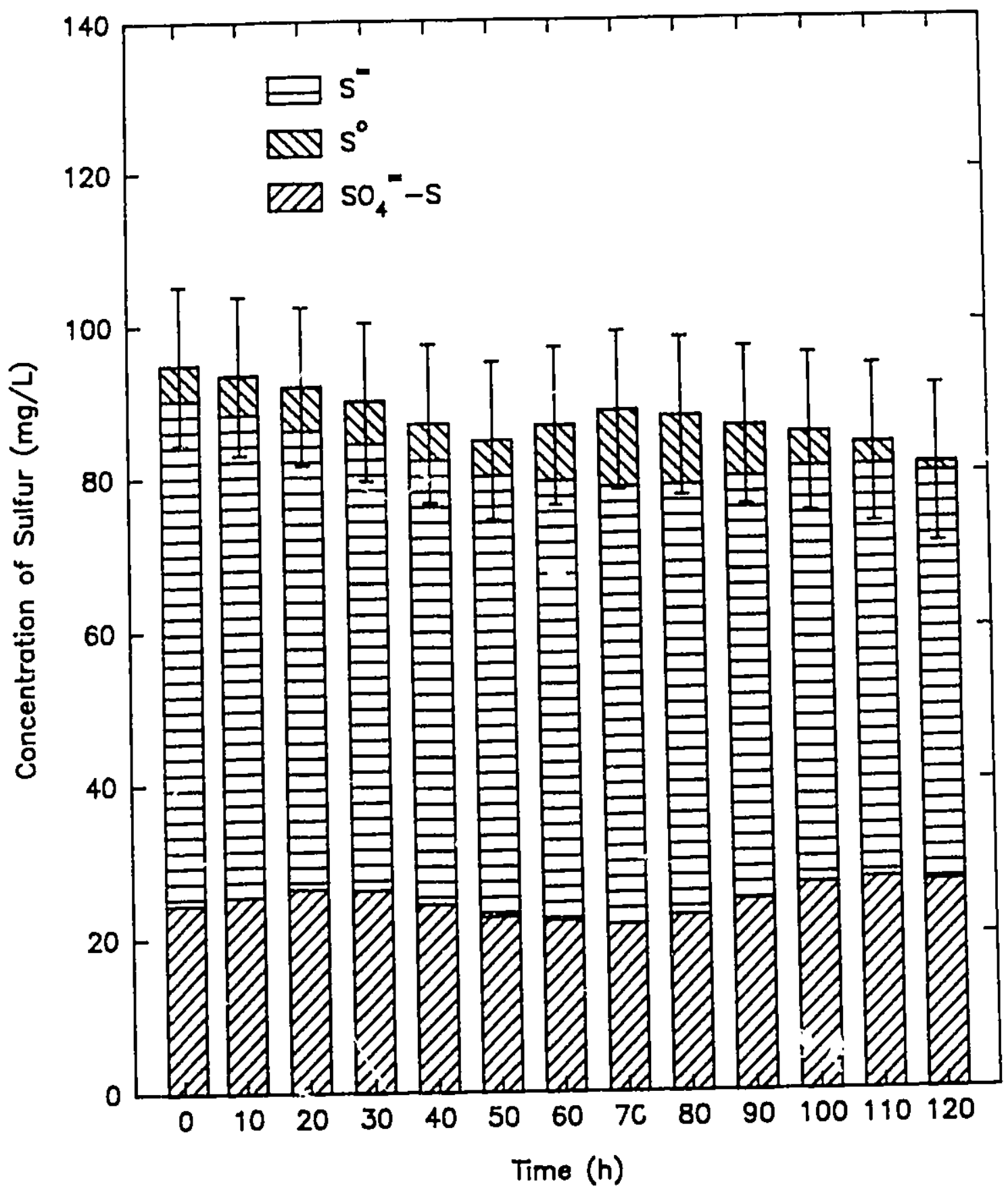

FIGURE 4.16 Sulfur Balance for Batch Reactor Control Run 1 


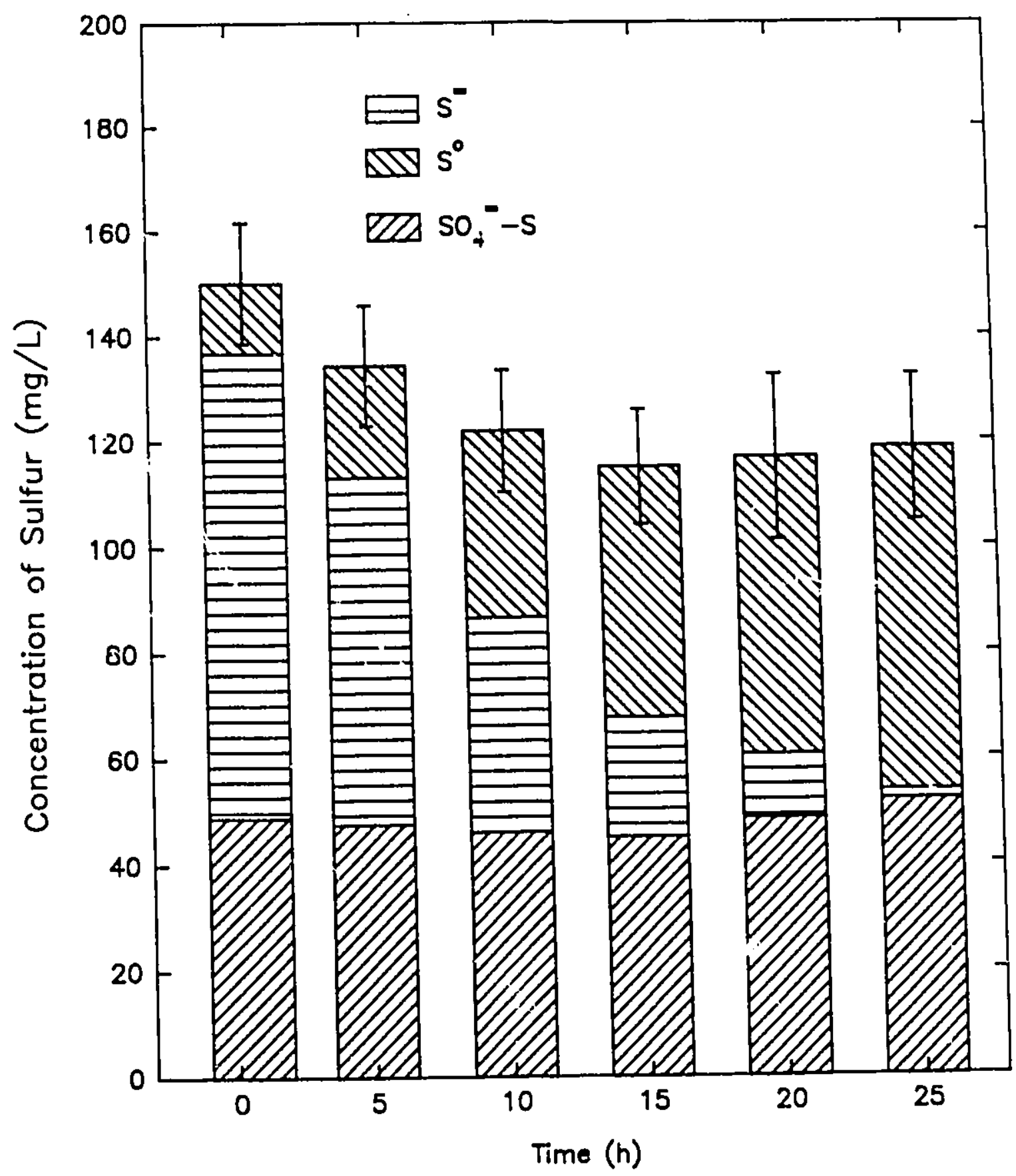

FIGURE 4.17 Sulfur Balance for Batch Reactor Run 2 


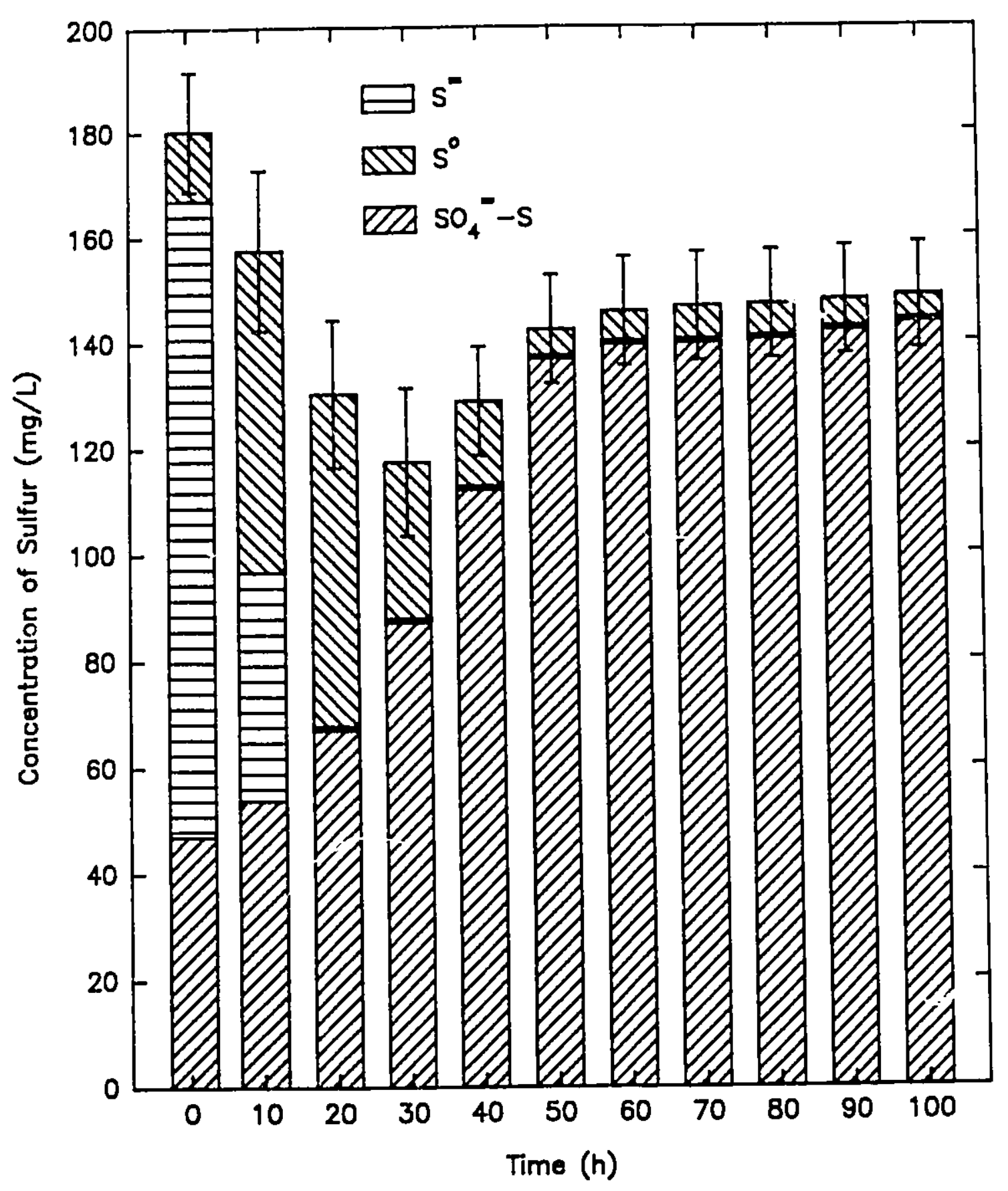

FIGURE 4.18 Sulfur Balance for Batch Reactor Run 3 


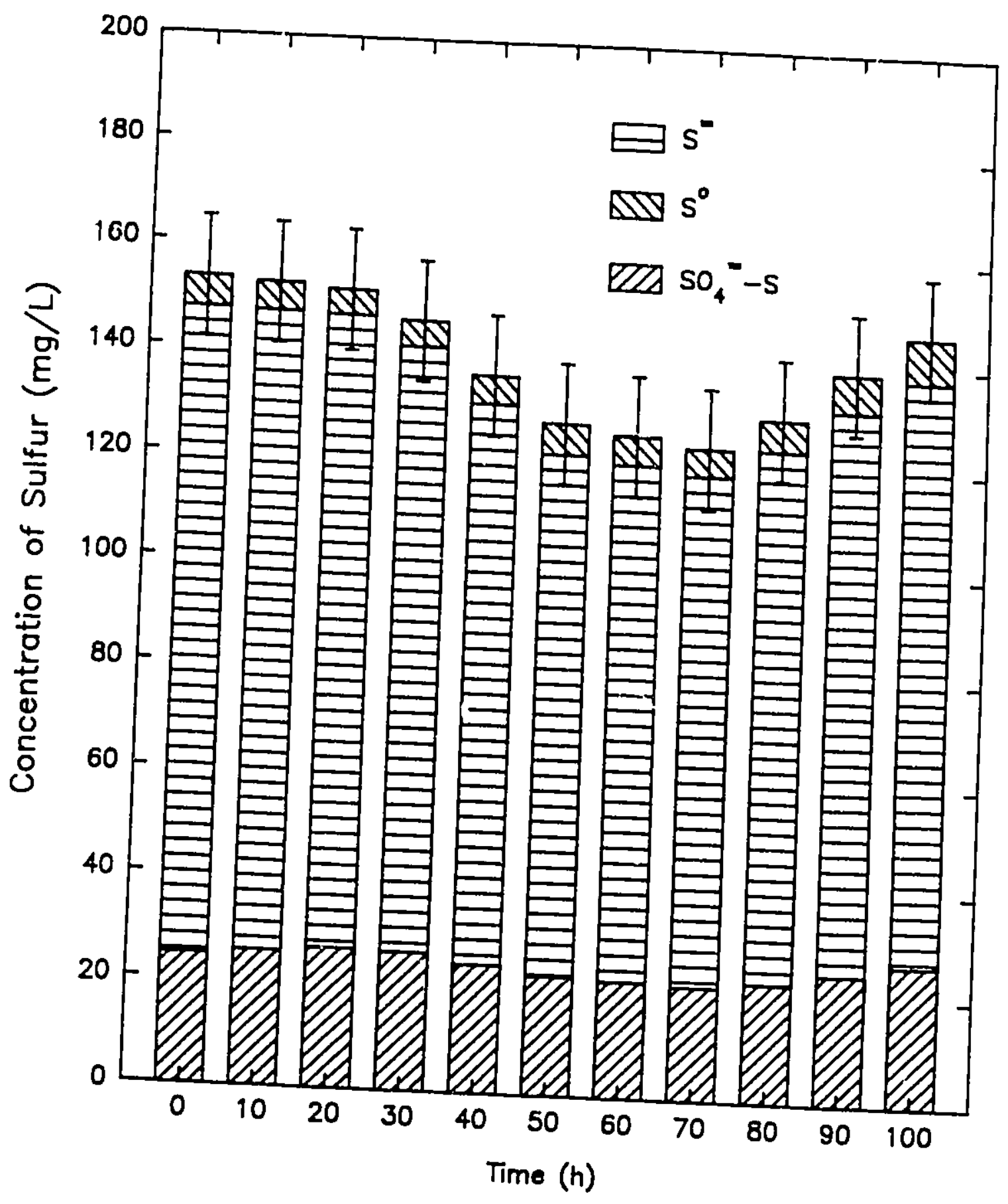

FIGURE 4.19 Sulfur Bolance for Batch Reactor Control Run 3 


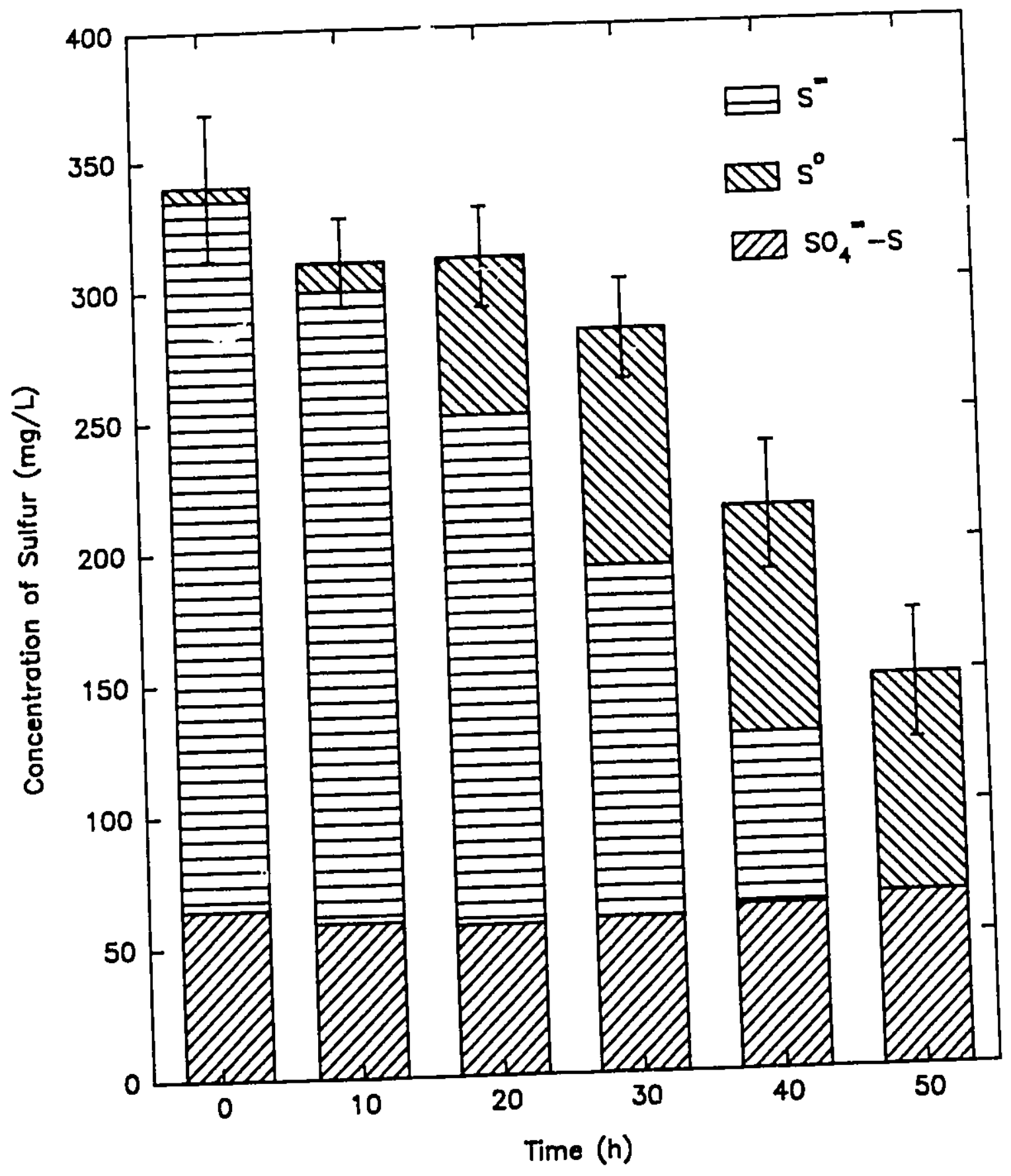

FIGURE 4.20 Sulfur Balance for Batch Reactor Run 5 


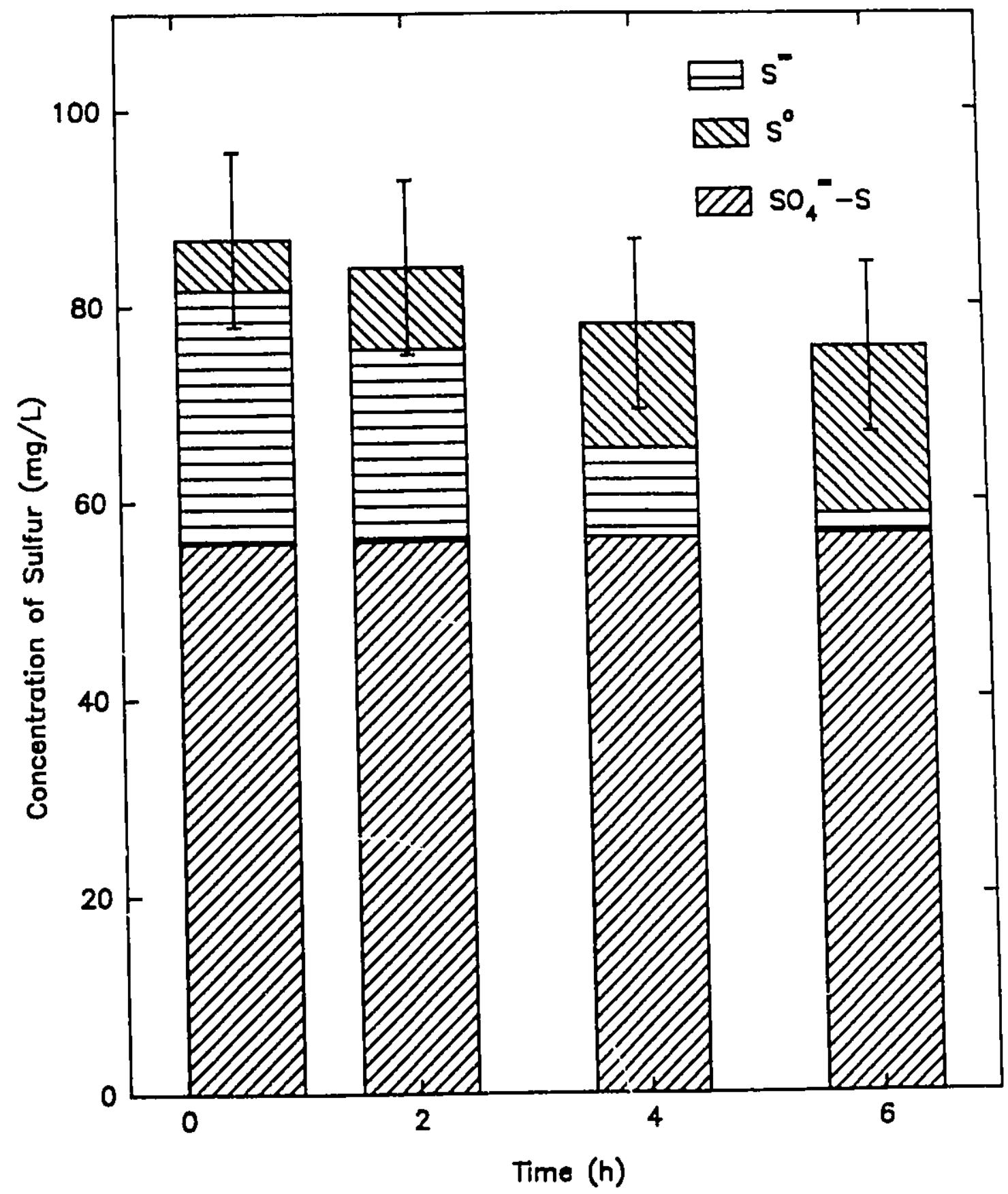

FIGURE 4.21 Sulfur Balance for Batch Reactor Run 6 


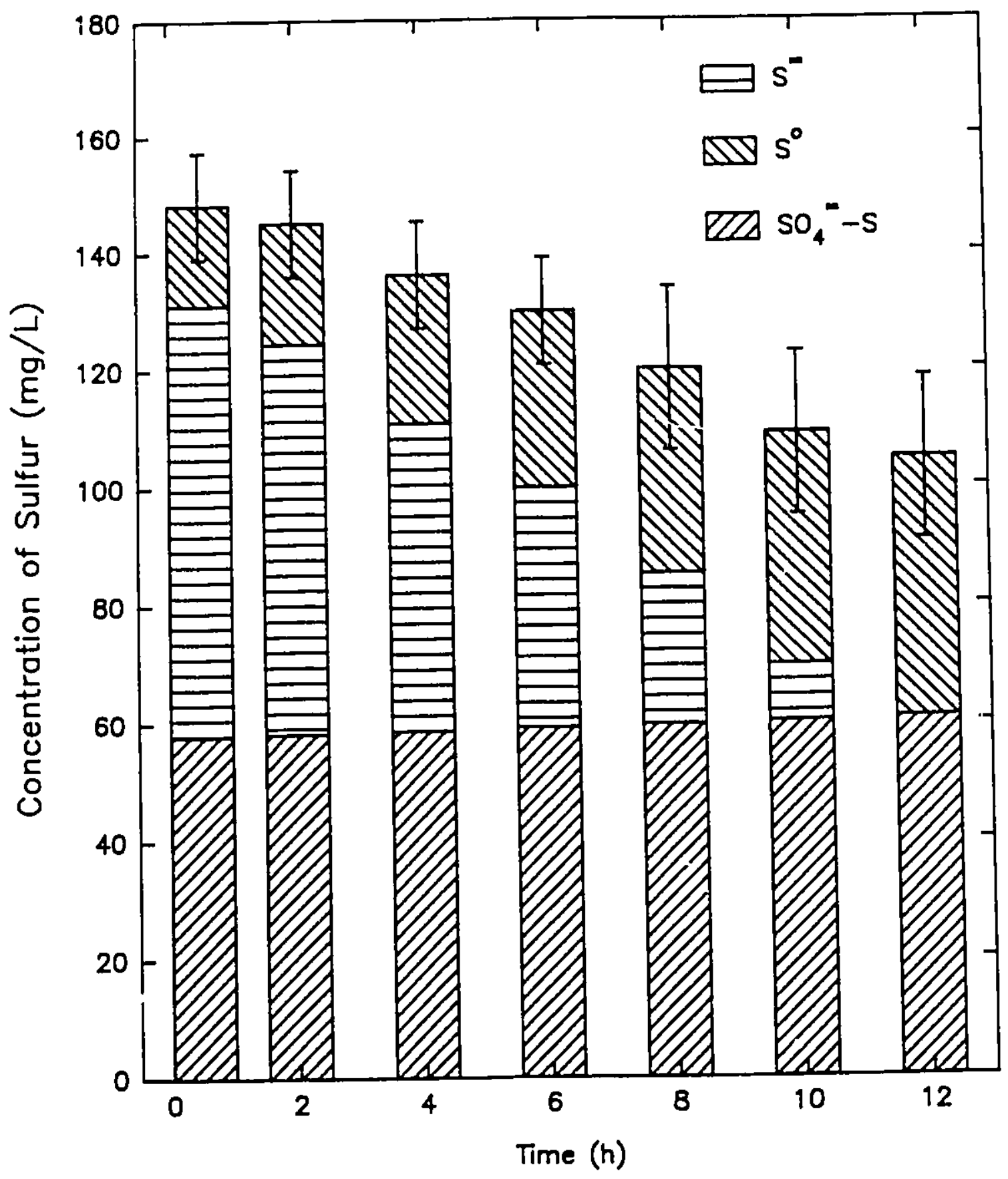

FIGURE 4.22 Sulfur Balance for Batch Reactor Run 7 


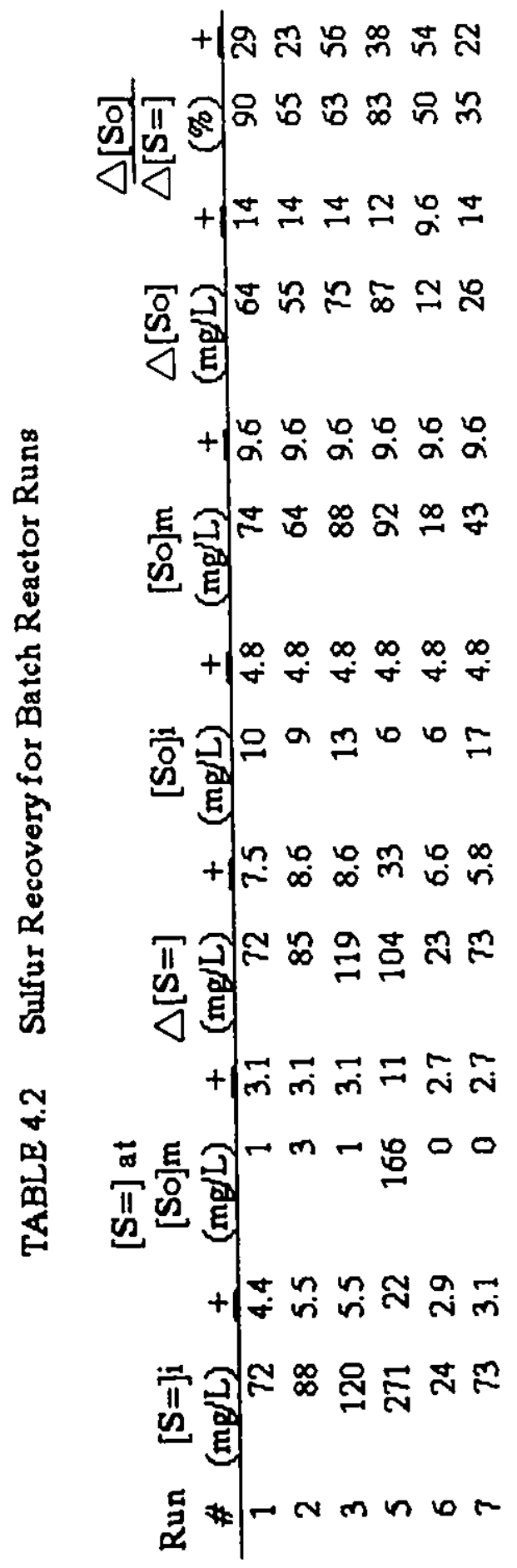


performed at the lowest concentration of each sulfur specles. The highest $s^{\circ}$ concentration occurs typically at the end of sulfide depletion, but in Run 5 it occurred mid-way through the sulfide utllization phase. As shown In Figure 4.30 later, the uncertainty of this recovery value was high owing to the subtraction of $S^{\circ}$ measurements of moderate uncertainty. There was no correlation betiveen percent recovery and the initial sulfide concentration.

\subsection{Seml-Batch Reactor Tests}

\subsubsection{Data}

Concentrations of sulfur species and bchl versus time are shown in Figure 4.23. Data points are Joined by straight lines. Where error bars are not shown, the data point symbol is larger than the error bar. The corresponding reactor environmental conditlons are plotted in Figure 4.24. The sudden increase in sulfide concentration at each injection was accentuated by drawing the line through a low point immediately before the time of the infection. The sulfide value at this point was considered to be equal to the value of the preceding point. As in the batch reactor tests, the decrease in sulfide was colncident with an increase in elemental sulfur. Sulfate, as the end-product of oxidation of sulfur accumulated in the reactor, reaching a concentration of $420 \mathrm{mgS} / \mathrm{L}$. Bchl readings were zero within the method uncertainty for the initial depletion of sulfide. The methanol used for the absorbance blanks in the bchl assay was found to be contaminated at 168 hours, so the results between 25 hours and 168 hours were discarded. Bchl measurements for Infections 2 to 4 ranged from 7.5 to $37.9 \mathrm{mg} / \mathrm{L}$ and were generally highex than in the batch reactor runs. 

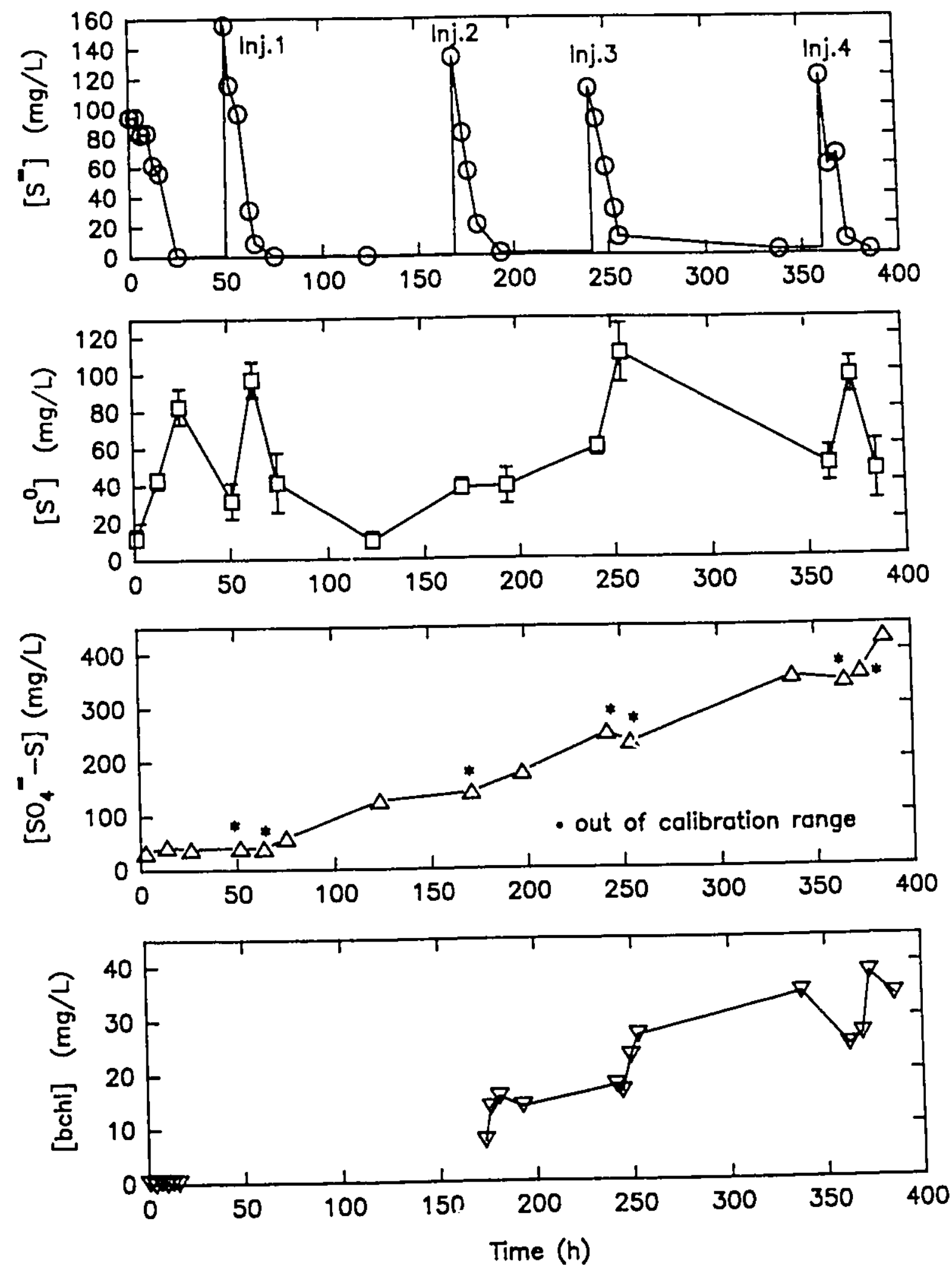

FIGURE 4.23 Concentrations in Semi-Batch Reostor 

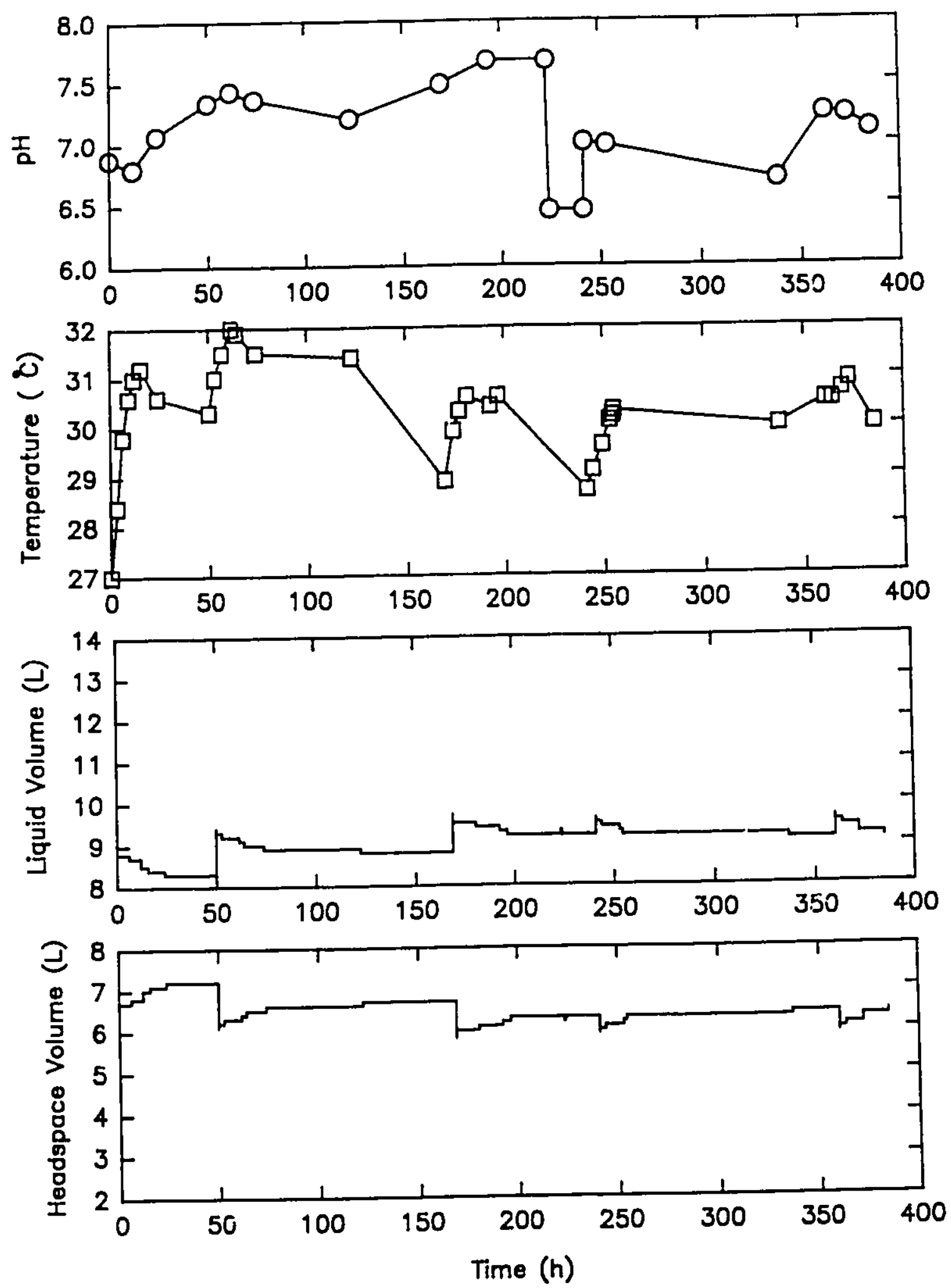

FIGURE 4.24 Reactor Environment for Semi-Batch Reactor 
At each infection, approximately 1 L of sulfide solution was added to the reactor thereby causing the dilution of elemental sulfur, sulfate ard bchl concentrations. This is most evident in Infection 4 where sulfate and bchl measurements were taken 24 hours before the injection.

The $\mathrm{pH}$ was adjusted at 224 hours as seen in Figure 4.24 by the addition of sterile $1 M$ HCl solution.

\subsubsection{Grouth of Bacterla}

Specific growth rates were calculated as in the batch reactor. These data are presented in Table 4.3 and plotted later in Figure 4.26.

\subsubsection{Sulfur Balance and Recovery}

Figure 4.25 shows the sulfur balance for the semi-batch reactor. An attempt was made to deplct the sulfur species profile immediately after the injection of sulfide, at the elemental sulfur maximum and after sulfide depletion. The error bars represent the cumulative uncertainties from the analyses of sulfide, elemental sulfur and sulfate. As in the case of the batch reactor, conversion of sulfide to $\mathrm{S}^{\circ}$ is not $100 \%$. The "loss" of sulfur to other specles is evident after Injections 1 and 2. Sulfur recovery ranged from 1 to 788 as shown in Table 4.4. Interpolations were performed as outlined in Section 4.1.3. In Injection 3, the draw at 193 hours probably missed the elemental sulfur peak resulting in a reported sulfur recovery of 18 .

\subsection{Discussion}

\subsubsection{Growth of Bacteria}

The values of specific growth rate obtained from batch and semi-batch reactor experiments are plotted against the initial concentration of sulfide (at the begining of the log-growth phase) in Figure 4.26. The 


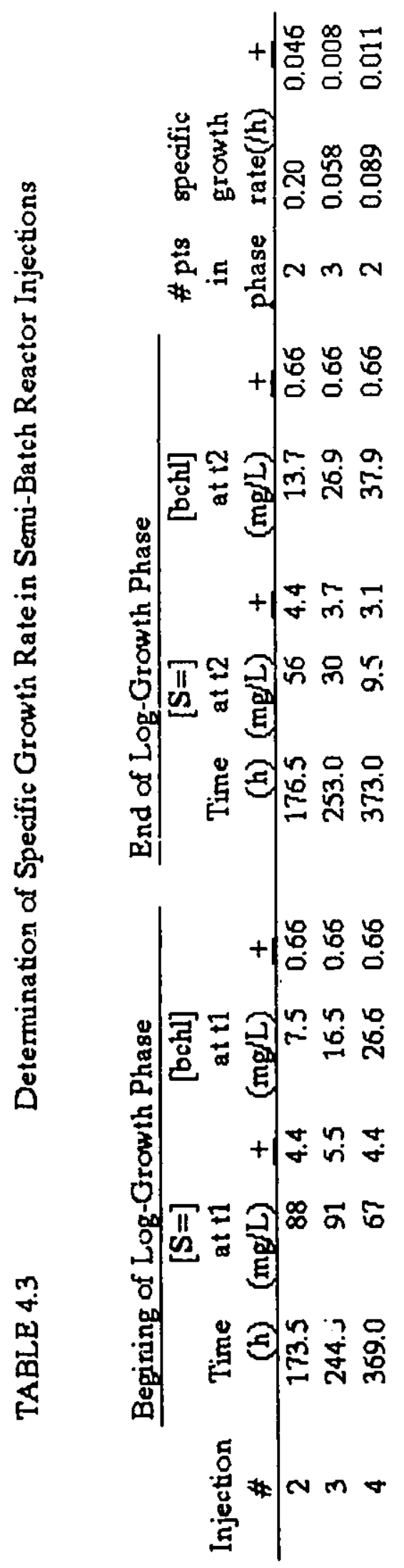




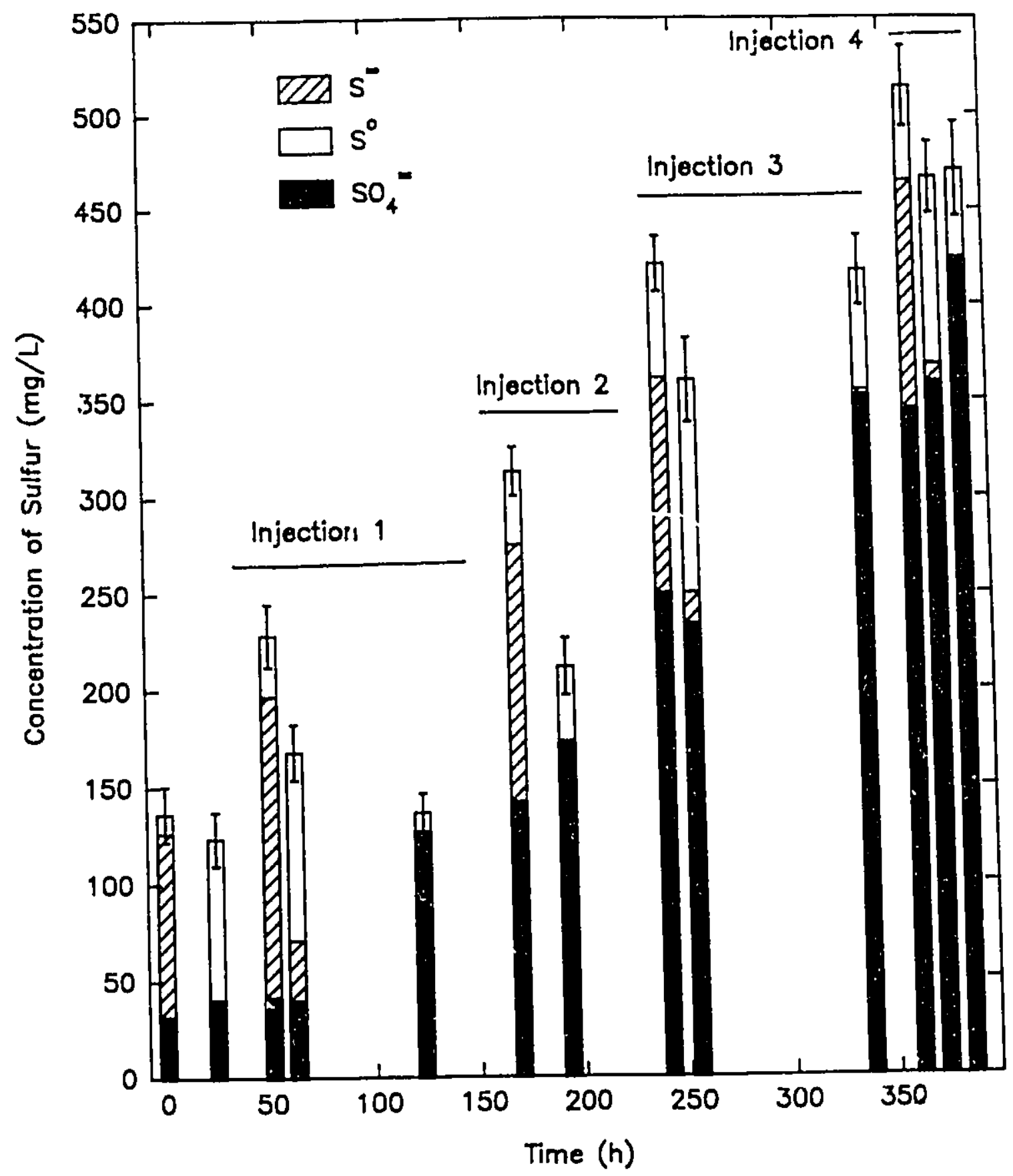

FIGURE 4.25 Sulfur Balance for Serni-Batch Reactor 


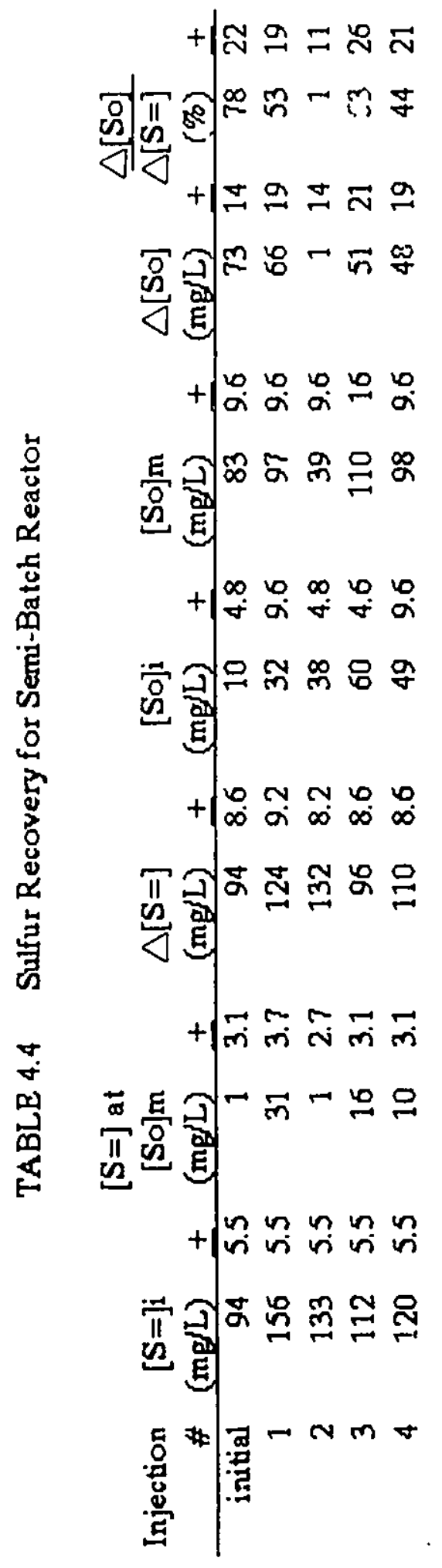




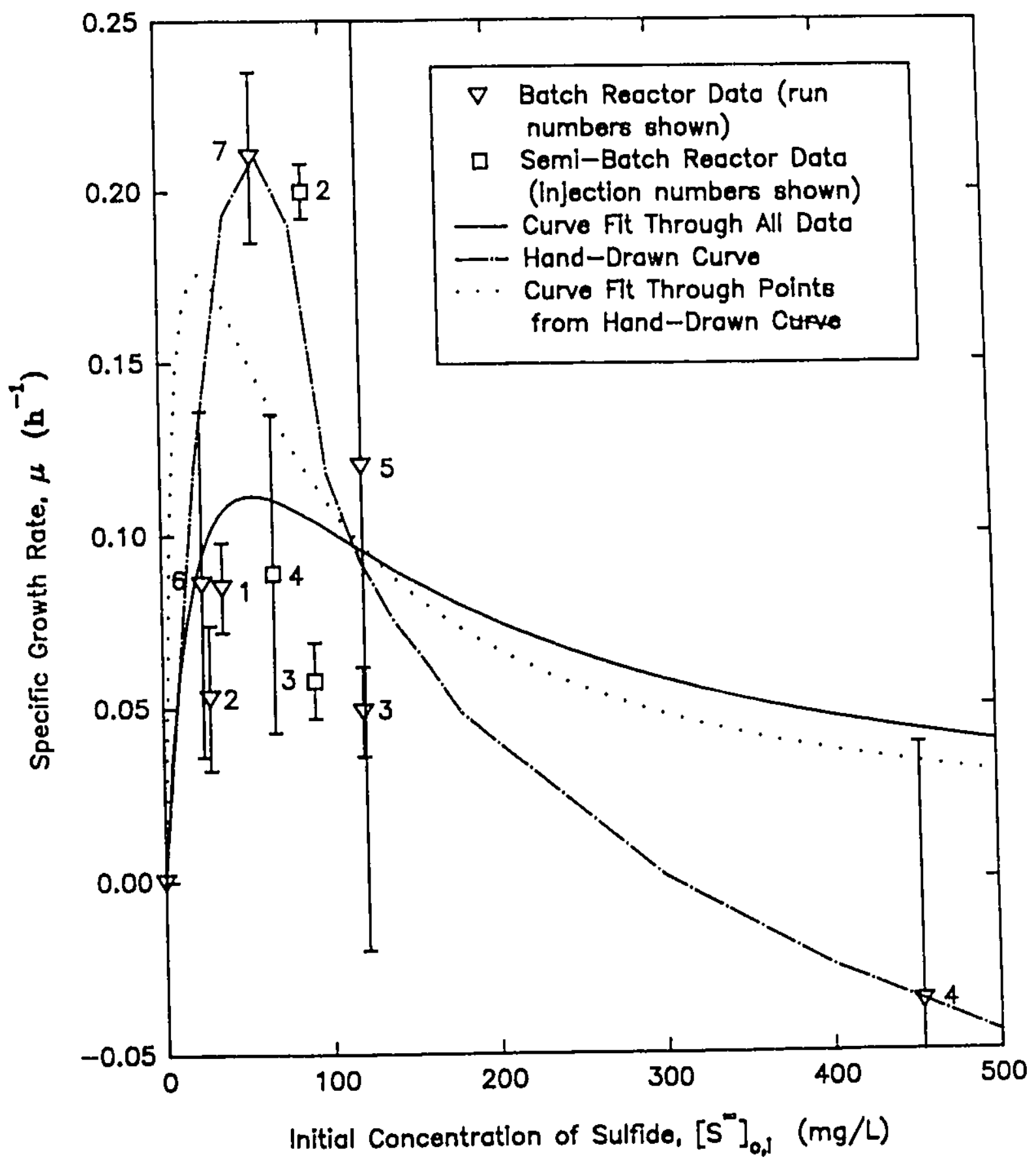

FIGURE 4.26 Specific Growth Rate of Bacteria versus Sulfide Concentration at Begining of Log-Growth Phose of Bacteria 
data were fitted to the Haldane Equation 2.12 with and without the point at $(0,0)$ with no difference in the result. The calculated values for parameters $\mu_{\text {max, }} K s$ and $K 1$, based on the entire data, were used to generate the solld line in Figure 4.26. Similarily, the data points from the hand-drawn curve (dot-dash line) were entered into the curve fitting program and the resultant parameters were used to draw the dotied line. The form of the equation does not allow a duplication of the hand-drawn line. For comparison, the parameters value are:

$\begin{array}{lccc}\text { Source of Data } & \mu_{\mathrm{max}}\left(\mathrm{h}^{-1}\right) & \mathrm{Ks}(\mathrm{mg} / \mathrm{L}) & \mathrm{Kd}(\mathrm{mg} / \mathrm{L}) \\ \text { experiment } & 0.446 & 54.7 & 54.6 \\ \text { hand-drawn } & 0.705 & 23.8 & 23.8\end{array}$

Maka (1986) obtained $\mu$ values of 0.01 to $0.15 \mathrm{~h}^{-1}$ in gas-fed static cultures of $c$. thiosulfatophilum where the total light energy ranged from 0.3 to $4.9 \mathrm{w}$. Cork et al. (1985) reported $\mu$ values of 0.033 to $0.050 \mathrm{~h}^{-1}$ In a similar reactor receiving a total of 2.1 to $28.8 \mathrm{~W}$ of 1 ight energy. The mafority of $\mu$ values in Figure 4.26 are in the 0.045 to $0.090 \mathrm{~h}^{-2}$ range, obtained with an incident light level of $7.1 \mathrm{w}$. From these cummlative data, it would seem that there is not a direct correlation between the specific growth rate and the incident light energy.

In batch studies with toxic substrates, the observed $\mu$ values do not approach Home with ar increase in the substrate concentration, ag they do for non-toxic substrates. This is due to the fact that the inhibitory effect increases as the substrate (food) concentration increases. In addition, the $\mu_{\text {max }}$ values in batch culture are usually lower than in continuous culture due to the dilution effect on the high substrate feed concentration (Gaudy et al.,1980). 
The maximum level of sulfide tolerable by $C$. thiosulfatophilum can be read from Figure 4.26. The lines of best fit do not cross the $\mu=0$ IIne, bound by the form of the Haldane equation. However, the observations of bacterial death at $457 \mathrm{mgs}^{2-} / \mathrm{L}$ and survival at $270 \mathrm{mgs}^{2-} / \mathrm{L}$ set the practical level for no bacterla growth at $300 \mathrm{mgs}^{2}-/ \mathrm{L}$. At this sulfide concentration, $\mathrm{S}^{2-}$ would be metabolized by the avallable $C$. thiosulfatophilum until its concentration is about $120 \mathrm{mgs}^{2-} / \mathrm{L}$, at which point the bacteria population would grow logarithmically.

The specific growth rate is affected mildly by the initial pH of the run or infection in addition to the sulficie concentration (Flgure 4.27). The correlation coefficient indicates that the null hypothesis that $\mu$ and pHo are not related can be rejected with 97.58 confidence. However, in sets of runs which have simllar pHo values but different sulfide concentrations at the begining of the log-growth phase, the Haldane relation applies. An example is the set of batch reactor Runs 6, 7 and 3 . Although the pHo values are between 7.27 and 7.47 , the speclfic growth rates are much different and conform to the peak of Figure 4.26 .

Figure 4.28 shows plots for calculating the true cell yleld. The slope of the lines in this figure are equal to the true cell yield. The increase in bchl from the beginning of the log-growth phase was calculated by subtracting the concentration of bchl at the beginning of the loggrowth phase from all subsequent bchl measurements. The decrease in concentration of sulfide was calculated by subtracting all sulfide values in the log-growth phase from the initial sulfide concentration at the beginning of the log-growth phase.

Values of $Y_{t}{ }^{*}$ range between 0.021 and 0.20 . In all semi-batch 


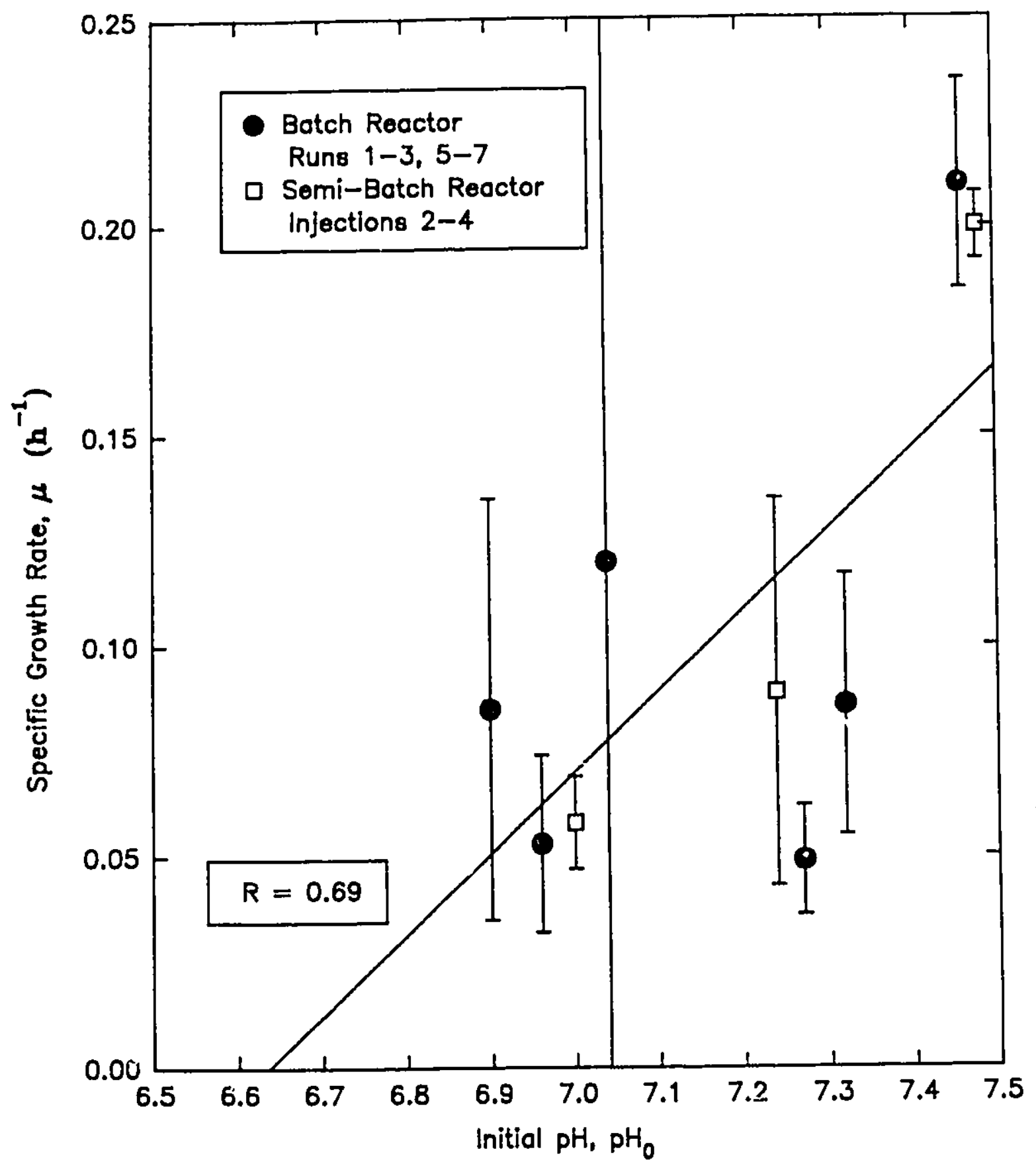

FIGURE 4.27 Specific Growth Rate versus Initial pH in Batch and Semi-Batch Reactors 


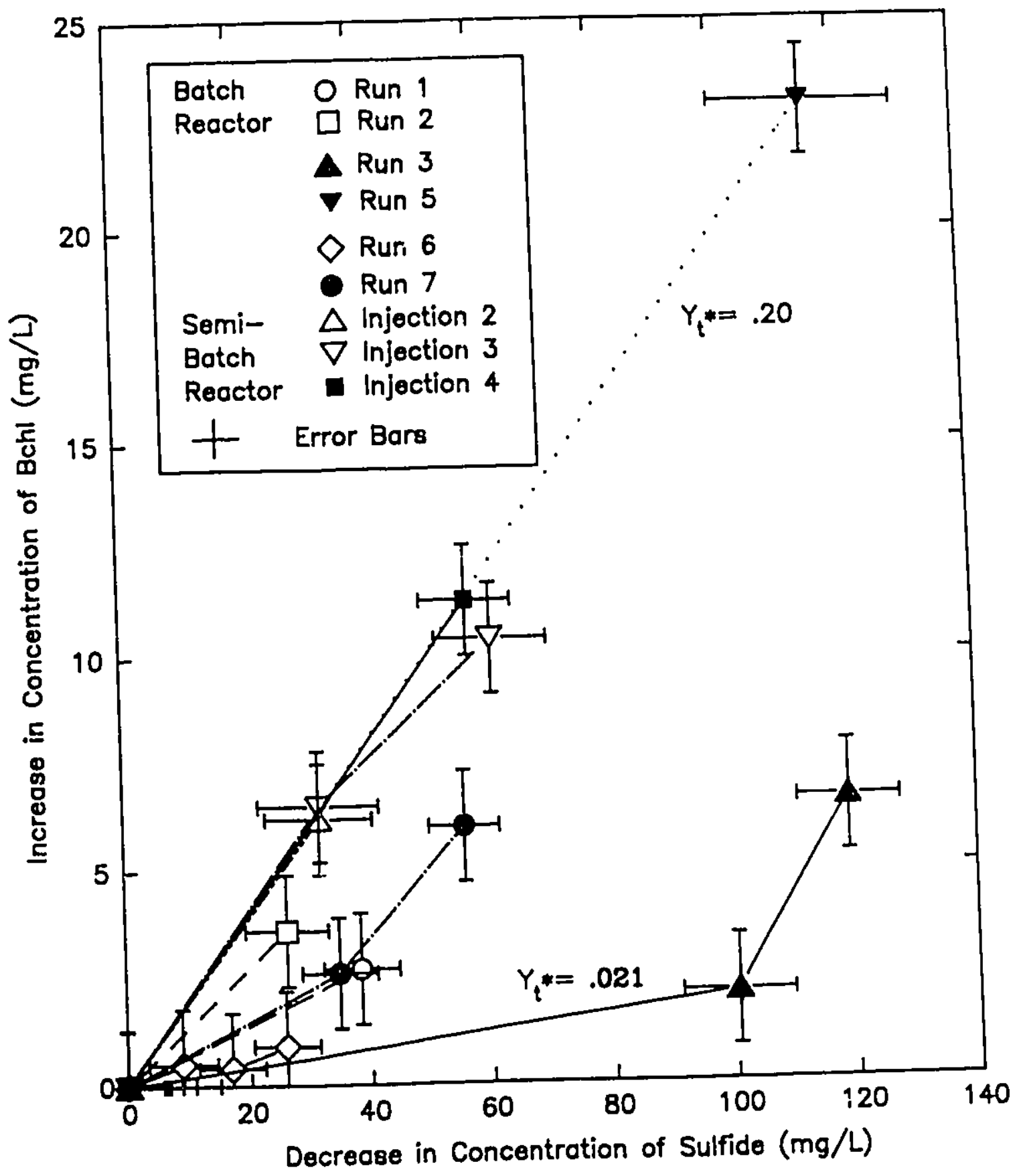

FIGURE 4.28 Plot for Calculation of True Cell Yield 
Injections, this value was consistently around 0.20 . Kakidas (1982) has reported that $1 \mathrm{mg} / \mathrm{L}$ of $\mathrm{bchl}$ corresponds to $36 \mathrm{mg}$ dry welght/L of blomass. Converting these yleld values to (mg dry weight bicinass)/t per (mg rulfide ut11lzed)/L gives a yleld range of 0.76 to 7.2 . This is up to elghteen times the typlcal values reported for wastewater (Section 2.3). Kakidas (1982) does not report the source of the ratio of bchl concentration to dry weight.

The theoretical maximum yield is calculated from Equation 2.2 as follows:

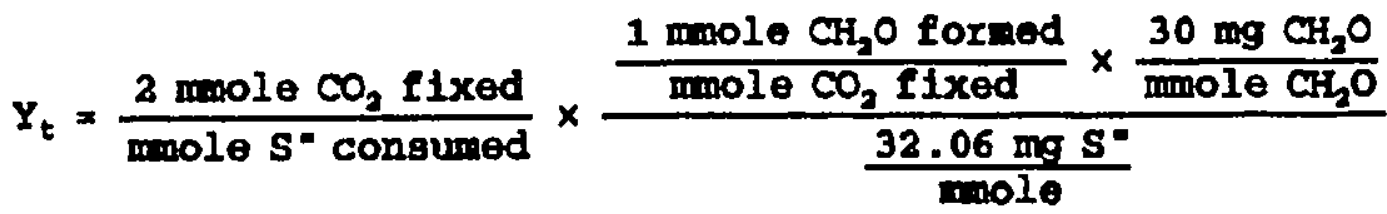

$$
\begin{aligned}
& -1.8 \mathrm{mg} \text { btomage formed } \\
& \text { mg } 8^{*} \text { consumed }
\end{aligned}
$$

Thus, if all of the metabolism of the bacterlum was directed at growth, $1.8 \mathrm{mg}$ of cell dry mass as $\mathrm{CH}_{2} \mathrm{O}$ would be formed for every $\mathrm{mg}$ of sulfide ut1lised. The actual cell mass created was different for two reasons. Bacteria need electron donors to carry out their metabolism. These anaoxygenlc photosynthetic bacteria obtain electrons both from the oxldation of sulfide and the activation of photosynthetic pigments. Thus sulfide is not the only source of electrons. Secondly, not all of the compounds needed for cell growth can be derived from $\mathrm{CO}_{2}$. Sone of the cell mass is created by assimilating nitrogen and sulfur compounds. 
The $\mu_{\max }$ and $Y_{t}{ }^{*}$ constants can be used in developing a preliminary model for a continuous flow reactor without recycle. At steady state, the speciflc growth rate in the reactor is equal to the dilution rate (D) or flow rate per unit volume. Rewriting the Monad Equation 2.11 and substituting $D$ for $\mu$, yields:

$$
S=\left[S^{2-}\right]=\left[S^{2-}\right]_{\text {efe }}=R_{*}\left(\frac{D}{H_{\max }-D}\right)
$$

The bchl concentration can be calculated from the change in substrate concentration by:

$$
[b c h l]=Y_{t}^{*}\left(\left[S^{2-}\right]_{\ln 1}-\left[S^{2-}\right]_{a c e}\right)
$$

Both $\left[\mathrm{S}^{2-}\right]$ ase and [bchl] are plotted as functions of the dilution rate in Figure 4.29. This is referred to as the dilute-out curve because it shows that without recycle there is a dilution rate at which the biomass concentration will be flushed out of the reactor.

\subsubsection{Sulfur Recovery}

There is a correlation between the recovery of sulfur and the initial $\mathrm{pH}$ in the reactor at the beginning of a run/injection (Figure 4.30). The corelation coefflclent of 0.82 allows us to refect the null hypothes 13 that percent recovery of sulfur and Initial pH are not related with 998 confidence. The relationship may be due to the fact that sulfate is the more stable form of sulfur at higher pH (Chen,1974) and thus would be formed in preference to sulfur.

\subsection{3 sulfide Utilization}

The rate of sulfide utilization, $d\left[s^{2-}\right] / d t$ was found to be 


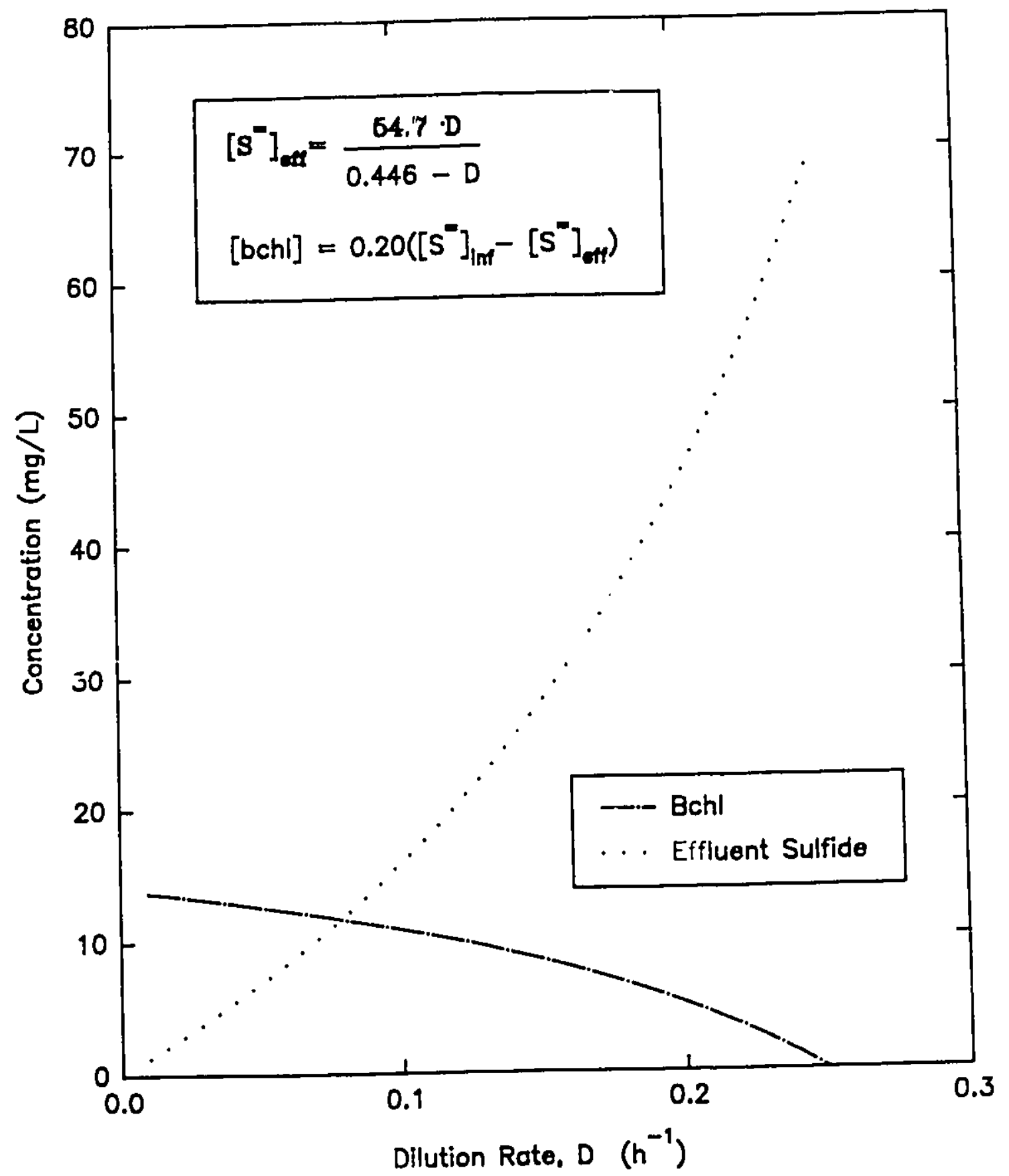

FIGURE 4.29 Dilute-out Curves in a Continuous-Flow Reactor Without Recycle 


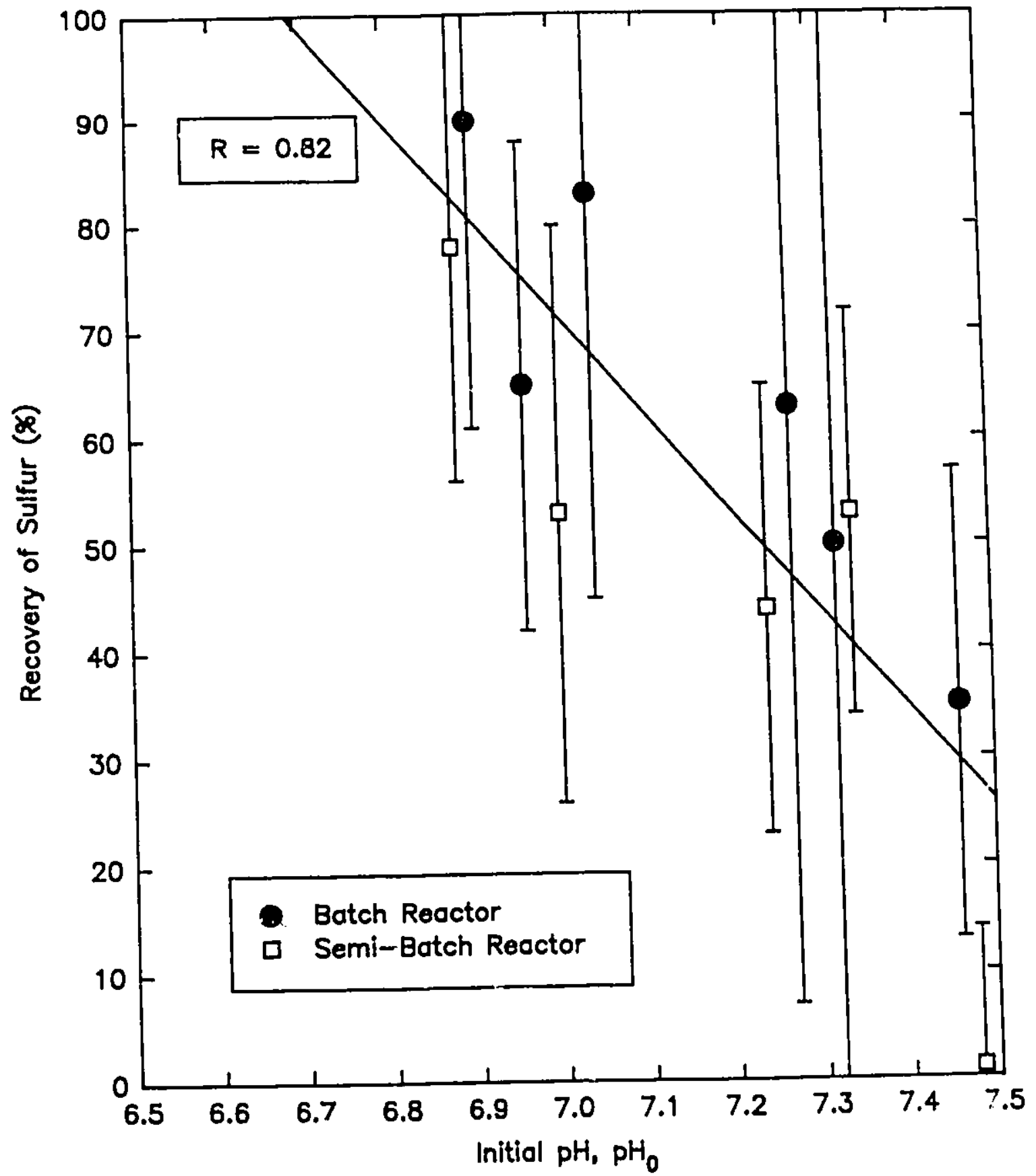

FIGURE 4.30 Recovery of Sulfur versus Initial pH in Batch and Semi-Batch Reactors 
uncorrelated to the concentration of sulfide in the reactor (Figure 4.31) or the concentration of bcill in the reactor (Figure 4.32). Similarlly, there no correlation $(R=0.15)$ between the specific utilization rate and sulfide concentration (Figure 3.33). $U$ is considered to be a constant in continuous flow design equations.

The maximum rate of sulfide utilization was found to be $9.4 \mathrm{mg} / \mathrm{L} \cdot \mathrm{h}$ In the batch reactor experiments. This value wes obtained in Runs 3 and 7. The highest rate of sulfide utilization achie'ved in the semi-batch reactor experiments $17.3 \mathrm{mg} / \mathrm{L} \cdot \mathrm{h}$ in Injection 4 . 


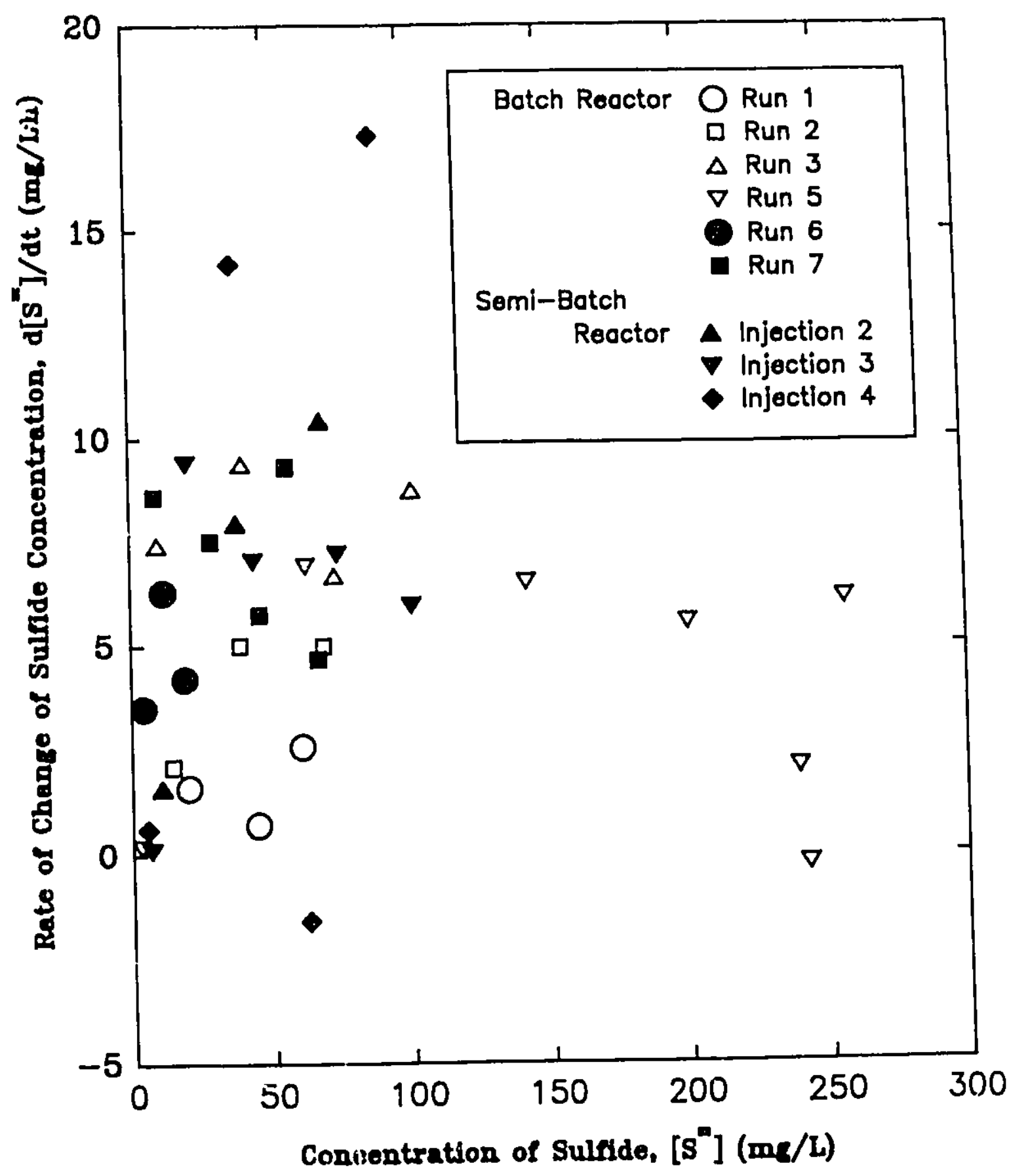

FIGURE 4.31 Rate of Change in Sulfide Concentration versus Sulfide Concentration in Batch and Semi-Batch Reoctors 


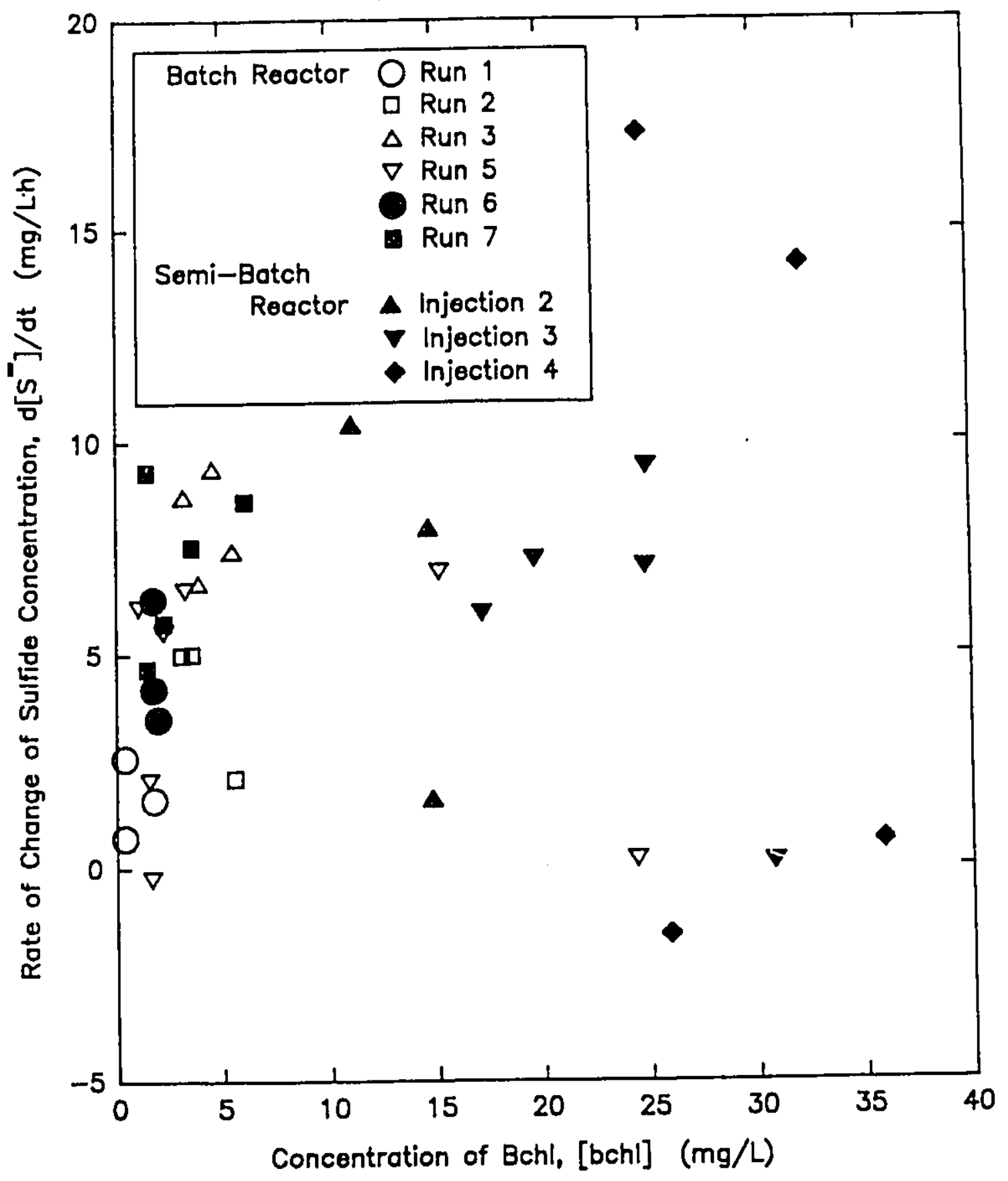

FIGURE 4.32 Rate of Change of Sulfide Concentration versus Bchl Concentration in Batch and Semi-Batch Feactors 


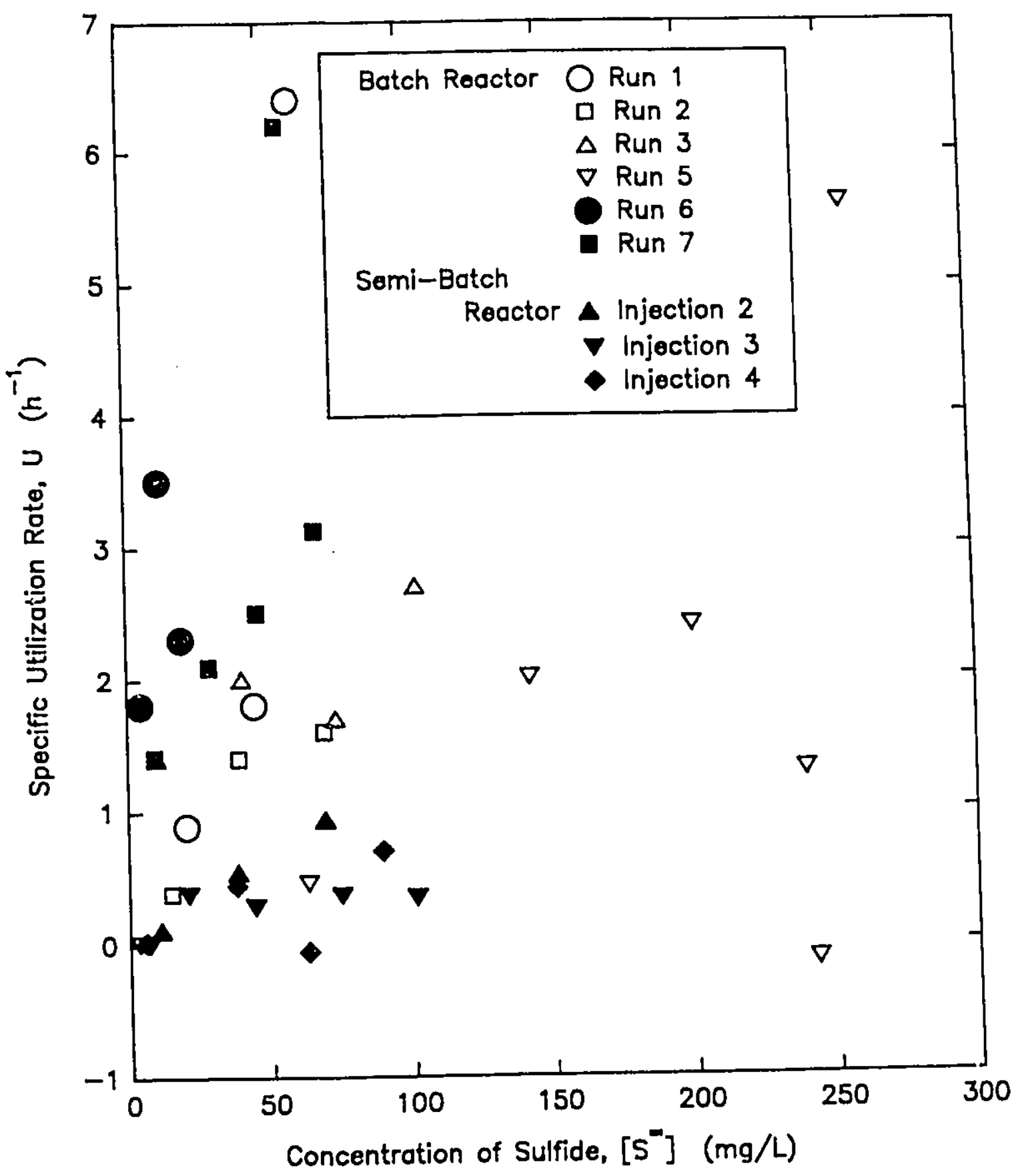

FIGURE 4.33 Specific Utilization Rate of Sulfide versus Sulfide Concentration in Batch and SemiBatch Reactors 


\section{CHFTER PIVB}

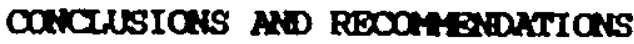

\subsection{Conclusions}

Based on batch and semi-batch experiments conducted in the laboratory, it is concluded that:

- Elemental sulfur was produced successfully from sulfide by $c$. thiosulfatophilum in a batch reactor.

-From 1 to $90 \%$ of the initial sulfide converted to elemental sulfur. By increasing the frequency of elemental sulfur sampling, the peak of sulfur concentration in a particular batch reactor run can be found more accurately, resulting in more realistlc measured recovery values. There was no correlation between the s recovery of sulfur and the initial sulfide concentration. However, the initial $\mathrm{pH}$ affected the sulfur recovery. This effect should be quantified further by using a more precise method of measuring elemental sulfur in an aqueous matrix. In addition, the operating conditions should be modifled to minimize the amount of sulfide conversion to thiosulfate.

-The values for specific growth rate of $C$. thiosulfatophilum ranged from 0.049 to $0.21 \mathrm{~h}^{-2}$ and were found to be similar to those obtained by others using a gas-fed semi-batch reactor. The maximum specific growth rate values have not been reported in these other studies.

-The maximum tolerable level of sulfide for $C$. thiosulfatophilum was found to be $300 \mathrm{mg} / \mathrm{L}$.

-The rate of sulfide utilization was determined to be independant of sulilde or bacterlochlorophyll concentration. The maximun rate of 
substrate utilization was found to be $17.3 \mathrm{mg} / \mathrm{L} \cdot \mathrm{h}$.

\subsection{Recomendations}

It is recommended that:

-A more precise and rapid method for measuring different sulfur specles be developed.

-The batch reactor be converted to a continuous flow reactor and operated in once-through mode. Using this tool, the parameters obtained In batch flow experiments can be confirmed and other parameters unique to continuous flow reactors can be determined.

- Once these parameters are established, a method of separating elemental sulfur from the bacteria, and the bacteria from water mist be developed so that the continuos flow reactor can be operated by recycling the biomass. 


\section{REGRPRives}

American Type Culture Collection (1985). ATOC Media Handbook. Rockville, Maryland: ATCC.

Anderson, J. W. (1978;. Sulfur in Blelogy. London: Edward Arnold (Publishers) Limited.

APHA, ALWA, WCPF (1989). STANDARD METHODS for the Examination of water and Wastewatex (17th ed.). Wasington, D.C.: American Public Health Assoclation.

Ass, G. Y., Shpiner, B. S., Pen, E. Z., Fed'kushov, Y. I., \& Shablevich, S. I. (1983). Removing Hydrogen Sulfide from wastewater from Mineral Water Baths by Biochemical Methods. Sov J wat Chem Technol, 5, p 102-7.

Bartlett, J. K., \& Skoog, D. A. (1954). Colorimetric Determination of Elemental Sulfur in Hydrocarbons. Anal Chem, 26, p 1008-11.

Baumann, E. W. (1974). Determination of Parts per Billion Sulfide in Water with the Sulfide-Selective Electrode. hal chem 46, No. 9, p 1345-7.

Bergstein, T., \& Cavar1, B. Z. (1983). Sulfide utilization by the Photosynthetic Bacter lum Chloroblum Phaeobacteroides. Hydroblologia, 106, p 241-6.

Brune, D. C., \& Gonzalez, I. (1982). Measurements of Photosynthetic Sulfide Oxidation by chlorobium using a Sulfide Ion Selective Electrode. Plant cell Physiol, 23, p 1323-8.

Buisman, C. J., wit, B., \& Lettinga, G. (1990). Biotechnological Sulphide Removal in Three Polyurethane Carrier Reactors: Stirred Reactor, Biorotor Reactor and Upflow Reactor. Wat Reg, 24, No. 2, p 245-51.

Buisman, C. P., Post, R., IJspeert, P., Geraats, G., \& Lettinga, G. (1989). Biotecnological Process for Sulphide Removal with sulphur Reclaimation. Acta Blotechnol, 9, No. 3, p 255-67.

Cadena, F., \& Peters, R. W. (1988). Evaluation of Chemical Oxidizers for Hydrogen Sulfide Control. J heCE, 60, No.7, p 1259-63.

Cooper, D. E., Maxwell, B. R., \& Hoo, C. (1975). Sulfide Reduction in Felimongery Effluent by Red Sulfur Bacterla. J WOPE, 47, p 2088-99.

Chen, K. Y. (1974). Chemistry of Sulfur Specles and Thelr Removal from Water Supply. In A. J. Rubin (Dd.), Chemistry of hater Supoly, Treatments. and Distribution (p 109-35). Ann Arbor, Mich.: Ann Arbor Science Publishers, Inc. 
Cork, D. J. (1978). Kinetics of Sulfate Conversion to Elemental Sulfur by a Bacterial Mutualism: A Hydrometallurgical Application. Ph.D. Dissertation. (pp 127). Tuscon: University of Arizona.

Cork, D. J. (1984). Microbial Conversion of Gypsum to Sulfur. US Patent Pending (Apol 407,659). (pp 23).

Cork, D., Mathers, J., Maka, A., \& Srnak, A. (1985). Control of Oxidative Sulfur Metabolism of Chlorobium 1imicola forma thiosulfatophilum. App Envix Mlckoblel, 49, No.2, p 269-72.

Cork, D. J., Jerger, D. E., \& Maka, A. (1986). Biocatalytic Production of Sulfur from Process Waste Streams. Biotechnol Bloeng, 16, p 149-62.

Cork, D. J. (1987). Photosynthetic Bioconversion Sulfur Removal. US Patent 4,666,852 (Appl 401,527). (pp 9).

Garlick, S., Oren, A., \& Padan, E. (1977). Occurence of Facultative Anoxygenlc Photosynthesis Among Fllamentous and Unicellular Bacteria. I Bact, 129, No. 2, p 623-9.

Gaudy, F. A., \& Gaudy, E. T. (1980). Microblology for Environmental Scientists and Engineers. (pp 736). Toronto: McGraw-H1ll Book Company.

Geadah, M.-L. (1987). Environmental status Report for the Canadian Petroleum Refinery Industry. Ottawa: Supply and Services Canada.

Gulens, J., Herrington, H. D., Thorpe, J. พ., Mainprize, ज., Cooke, M. G., Dal Bello, P., \& MacDougall, S. (1982). Comparison of Sulfide-selectlve Electrode and Gas-Stripping Monitors for Hydrogen Sulfide in Effluents. Anal Chim_Acta, 138, p 55-63.

Hansen, T. A., \& van Gemerden, H. (1972). Sulfide Utilization by Purple Nonsul fur Bacteria. Arch Microblol, 86, p 49-56.

Kakldas, L. B. (1982). Bloconversion of Hydrogen Sulfide and Carbon Dloxide to Starch by Chlorobium 1imicola forma thiosulfatophilum. Master's Thesis, (pp 87) Chicago: Illinois Institute of Technology.

Karavaiko, G. I., \& Pivovarova, T. A. (1977). Mechanism of oxidation of Reduced Sulfur Compounds. In W. Schwartz (Ed.), Conference Bacterial Leaching (p 37-46). Weinheim, New York: Verlag Chemie.

Knobloch, K. (1966). Photosynthetic Oxidation of Sulfide by Green Plants. Planta (Berl), 70, p 73-86.

Kobayashi, H. A., Stenstrom, M., \& Mah, R. A. (1983). Use of Photosynthetic Bacteria for Hydrogen Sulfide Removal from Anaerobic Waste Treatment Effluent. Rat Res, 17, p 579-87. 
London, J. P. (1964). The Path of Sulfux in Sulfide and Thiosulfate Oxidation by Members of the Genus Thiobacilius. Ph.D. Dissertation. (pp 180). University of Southern California.

Madigan, M. T. (1988). Microbiology, Physlology, and Ecology of Phototrophic Bacterla. In A.J.B. Zehnder (Bd.), Blology of Anaeroblc Microorganisms (p 39-111). Toronto: John wiley \& Sons.

Maka, A. (1986). Control of Oxidative Sulfur Metabolism in Chloroblum. Ph.D. Dissertation. (pp 155) Chicago: Illinols Institute of Technology.

Maree, J. P., \& Strydom, W. F. (1985). Blological Sulphate Removal in an Upflow Packed Bed Reactor. Wat Res, 19, p 1101-6.

Maree, J. P., Gerber, A., \& Strydom, W. F. (1986). A Blologlcal Process for Sulfate Removal from Industrial Effluents.

Maree, J. P., \& Strydom, W. F. (1987). Blological Sulphate Removal from Industrlal Effluent in an Upflow Packed Bed Reactor. Rest Res, 21, p 141-6.

Material Safety Data Sheet (1988). Sodium Sulfide (ACS 852). Toronto: BDH Inc.

Mathers, J. J., \& Cork, D. J. (1985). Microcomputer-Based Gas Control Schemes for Investigating Sulfur oxidation of chlorobium Iimicola forma thiosulfatophilum. Dev Ind Microbiel, 26, p 581-5.

Ministry of the Environient, Ontario (1987). Environmental Contaminants in Petroleum Refinery tastematers: An Assessment of current Information and a Monitoring Aporoach. : Queen's Printer for Ontario.

Ministry of the Environment, Ontario (1988a). The Economic and Financial Profile of the Petroleum Refining Sector. : Queen's Printer for Ontario.

Ministry of the Environment, Ontario (1988b). Effiluent Monitoring Regulations for the Petroleum Refining Sector. : Queen's Printer for Ontario.

Nemerow, N. L. (1978). Industrial water Pollution: Or jains Characteristics and Treatment. Don Mills, Ont.: Addison-Wesley Publishing Company.

Orion Research Inc. (1980). Model 94-16 silver/Silver sulfide Electrode Instruct ion Manual.

Roy, A. B., \& Trudinger, P. A. (1970). The Blochemistry of Inorganic Compounds of Sulphur. Cambridge: University Printing House.

Rozek, B., Marchewczyk, E., Kuhny, A., \& Konopka, E. (1978). Microblal Degradation of Hydrogen Sulfide from Industrlal water in Sulfur Mines. Rolish Patent 98,5134 (Appl 186,058). (pP 2). 
Salkinoja-Salonen, M. S., Hakulinen, R., Silakoski, L., Apajalahti, J., Backstrom, V., \& Nurmiaho-Lassila, E. L. (1985). Fluidized Bed Technology in the Anaerobic Treatment of Forest Industry wastewaters. Wat Scl Tech, 17 , p 77-88.

Schmidt, G. L., \& Kamen M.D. (1970). Variable Cellular Composition in Growing Cultures. Arch Microblel, 73, p 1-18.

Sclence Counc1l of Canada (1988). Water 2020: Sustalnable use for water in the 21st century. Ottawa, Ont.: Minister of Supply and Services.

Slefert, E., Irgens, R. L., \& Pfennig, N. (1978). Phototrophic Purple and Green Bacteria in a Sewage Treatment Plant. Appl Envir Microblol, 35, p 38-44.

Sitting, M. (1978). Air Pollution Control. Petroleum Refining Industry Energy Saving and Environmental control, p 104-34.

Skoog, D. A., \& West, D. M. (1982). Eundamentals of Analytical Chemistry (4th ed.). Toronto: Saunders College Publishing.

Stainer, R. Y., Doudroff, M., \& Adelberg, E. A. (1957). The Microblal Werld. Englewood Cliffs, N. J.: Prentice-Hall.

Stainer, R. Y., Adelberg, E. A., \& Ingraham, J. (1976). The Micrubial Whald. Englewood Cliffs, N. J.: Prentice-Hall.

Sublette, K. L. (1987a). Aerobic Oxidation of Hydrogen Sulfide by Thiobacillus Denitrificans. Blotechnol Bloeng, 29, p 690-5.

Sublette, K. L., \& Sylvester, N. D. (1987b). Oxidation of Hydrogen Sulfide by Mixed Cultures of Thiobacillus Denitrificans and Heterotrophs. Biotechnol Bioeng, 29, p 759-61.

Sublette, K. I., \& Sylvester, N. D. (1987C). Oxidation of Hydrogen Sulfide by Thiobacillus Denitrificans: Desulfurization of Natural Gas. Blotechnol Bloeng, 29(2), p 249-57.

Tortora, G. J., Funke, B. R., \& Case, C. L. (1989). Mlaroblology: an Introduction (3rd ed.). Don Milis, ont.: Benfamin/Cumings Publishing Co. Inc.

Truper, H. G., \& Fischer, U. (1982). Anaerobic Oxidation of Sulfur Compounds as Electron Donors for Bacterial Photosynthesis. In J. R. Postgate, \& D. P. Kelly (Eds.), sulphur Bacteria (pp 529). Great Britain: Phil. Trans. R. Soc. Lond.

Truper, H. G., \& Schlegel, H. G. (1964). Sulphur Metabolism in Thiorhodaceae 1. Quantitative Measurements on Growing Cells of Chromatium oken11. Antonie van Leeuwenhoek, 30, p 225-38. 
U.S. Environmental Protection Agency (1990). FACT SHFrET: Drinking Water Requlations Under the Safe Drinking Water Act. Washington, D.C.: USEPA.

van Gemerden, H. (1968). Growth Measurements of Chromat lum cultures. Arch vicroblel, 64, p 103-10.

van Gemerden, H. (1984). The Sulfide Affinity of Phototrophic Bacterla in Relation to the Location of Elemental Sulfur. Arch Mlcroblel. 139, p 289-94.

van Gemerden, H. (1986). Production of Elemental Sulfur by Green and Purple Sulfur Bacterla. Arch Mlarobiol, 146, p 52-6.

Vasan, S. (1978). Holmes-Stredford Process offers Economic $\mathrm{H}_{2} \mathrm{~S}$ Removal. Oil and Gas J, 76, p 78-80. 


\section{FPPEDTX A}

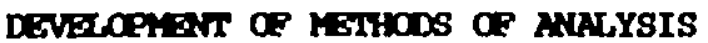

\section{A.1 General}

\section{A.1.1 Reagents}

dithzO is distilled water (conductivity $=5$ to $7 \mu \mathrm{mho} / \mathrm{cm}$ )

detho is deionized water (conductivity $=1.3 \mu \mathrm{mho} / \mathrm{cm}$ )

dadelzo is deaerated, deionized water. Delonized water was boiled in a coverad beaker or erlenmeyer Elask for at least five minutes. The beaker or flask was placed in a cold water bath and cooled until tepid.

Sulfide stock solution was made by rinsing sodium sulfide ( $\mathrm{Na} 2 \mathrm{~S} \cdot 9 \mathrm{H}_{2} \mathrm{O}$ ) crystals in $\mathrm{deH}_{2} \mathrm{O}$, patting them dry with a paper towel, welghing them and transferring them to a volumetric flask. The bulk of the flask was fllled with $\mathrm{dadeH}_{2} \mathrm{O}$ and $\mathrm{deH}_{2} \mathrm{O}$ was used to adjust the liquid level to the mark. In Sections A.3 and A.4, the methylene blue method of Section 3.1.1 was used to determine the sulfide content of this stock on the day of use.

Sulfur stock colloidal solution was made by adding a measured amount of recrystallized (in benzene), dried roll formed sulfur to an erlenmeyer flask with a ground glass foint. 958 ethanol was added $(0.8$ to 1.0 $\mathrm{mL} / \mathrm{mgS}^{\circ}$ ) and the mixture was cooled unt 11 bolling stopped and poured into a volumetrlc flask half full of $\mathrm{deH}_{2} \mathrm{O}$. The "milk of sulfur" formed was stable for one to two days. On the second day, the precipltated sulfur could be re-suspended by stirring. This solution was used as a sulfur interference for testing the sulfide and sulfate methods of analysis.

Sulfate stock solution was made by dissolving a measured quantity of 
dried sodium sulfate $\left(\mathrm{Na}_{2} \mathrm{SO}_{4}\right)$ in $\mathrm{deH}_{2} \mathrm{O}$ in a volumetric flask. The solution was made up to the mark with $\mathrm{deH}_{2} \mathrm{O}$.

\section{A.1.2 Apparatus}

All absorbance measurements were made with a Pye Unlcam SP500 Series 2 Spectrophotometer in the direct readout mole using a $10 \mathrm{~mm}$ quartz curvette. All absorbance measurements are reported in Optical Density units (O.D.).

An International Centrifuge Centra-4 with a 215 rotor was used to centrifuge samples.

\section{A.1.3 Statistical Analysis}

$x$ is the mean of a set of values.

uss is the uncertainty of a mean at the 958 confidence level. The value is calculated by (APHA, 1989):

$$
u_{0,0}=t_{.028, n-1}(s / \sqrt{n})
$$

where

$$
\begin{array}{ll}
\mathbf{s} & =\text { sample standard deviation } \\
\mathbf{n} & =\text { number of values } \\
t .02 s, n-1 & =\text { critical value at the } 958 \text { confidence level }
\end{array}
$$

CV is the coefficient of variation. It is calculated by (APHA, 1989):

$$
C V=100(8 / x)
$$

Linear regressions were performed by the computer program Sigmaplot Version 4.0 (Jandel Scientific, Sausalito,CA). The 958 confiderive limits and the sample correlation coefficient, $\mathbf{R}$ of the linear regression line were also computed by this program. The correlation coefficient is a measure of how accurately the line of best fit accomodates the data. 


\section{A. 2 Sulfide}

\section{A.2.1 Iodometric Method}

Standard Methods 4500-S ${ }^{2-}$ E. (APHA, 1989) describes the lodometric method wherein an lodine ( $I_{2}$ ) solution is added in excess to a suifide sample. The lodine reacts with the sulfide, after which the excess iodine is back-titrated with a thiocyanate solution. The sodium thiocyanate $\left(\mathrm{Na}_{2} \mathrm{~S}_{2} \mathrm{O}_{3}\right)$ solution had been standardized against a potassium b1-iodate $\left(\mathrm{KH}\left(\mathrm{IO}_{3}\right)_{2}\right)$ solution. The lodine solution had been standardized against the thiosulfate solution.

This method suffers interference from substances that reach with Iodine (thiosulfate, sulfite) so a sample pretreatment is suggested (APHA, 1989). The pretreatment consists of adding zinc acetate to the sulfide sample to precipltate zinc sulfide. The precipitate is filtered and resuspended in water for use in the lodometric test. An investigation into the precision and accuracy of the lodometric method with and without sample pretreatment was undertaken. The quantities of reagents used are given in Table A.1. The procedures used were as follows:

A. Blank

Delonized water $\left(\mathrm{deH}_{2} \mathrm{O}\right)$ wes added to a $250 \mathrm{~mL}$ erlenmeyer flask. The standardized lodine solution was added from a pipette or burette to the flask and HCl was added. The solution was titrated with standardized thiosulfate solution from a $50 \mathrm{~m}$ burette until the brown/red lodine colour faded to a straw colour. Then, a starch indicator was added, turning blue in the presence of lodine so that the endpoint could be detected to within a drop. 


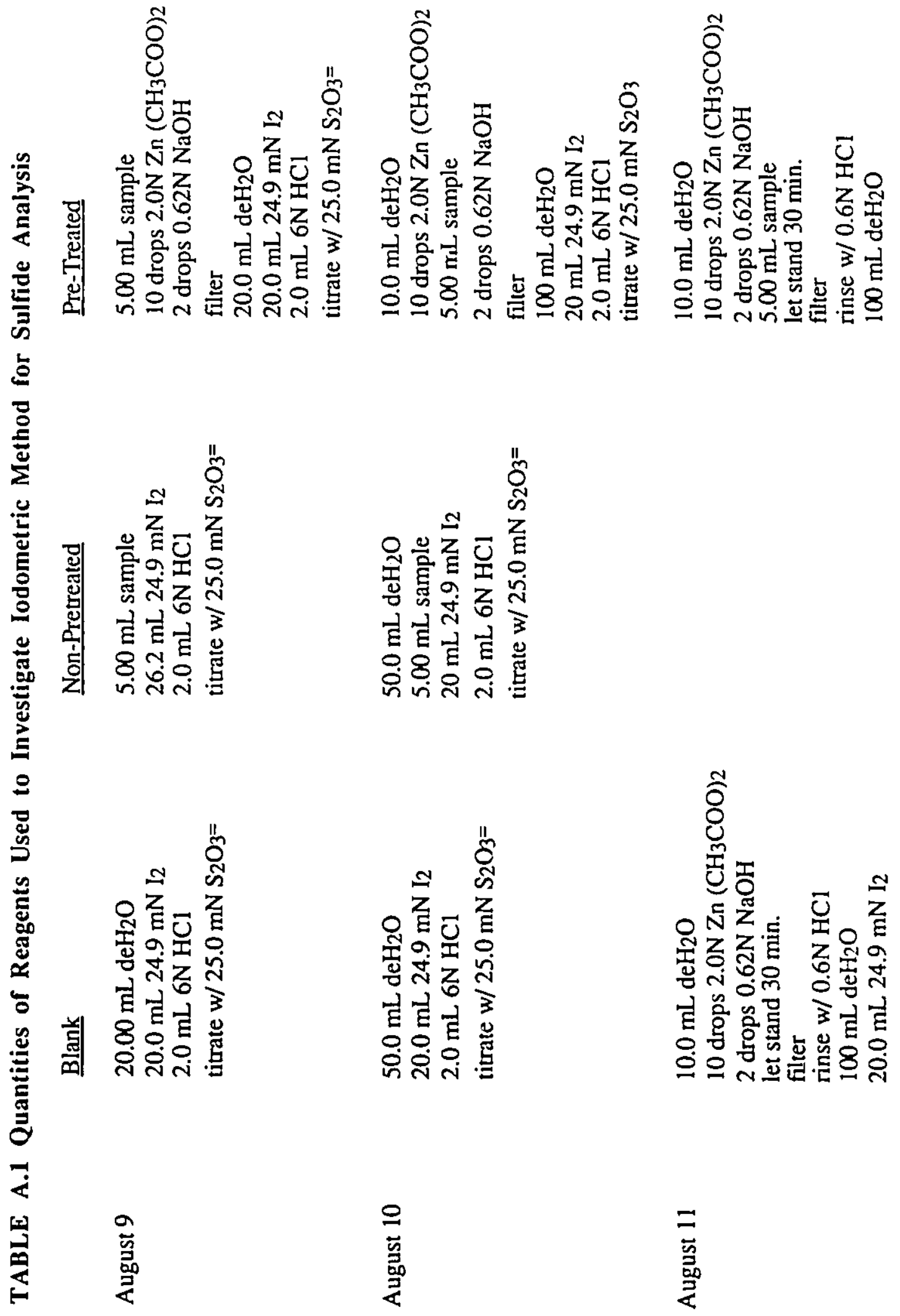



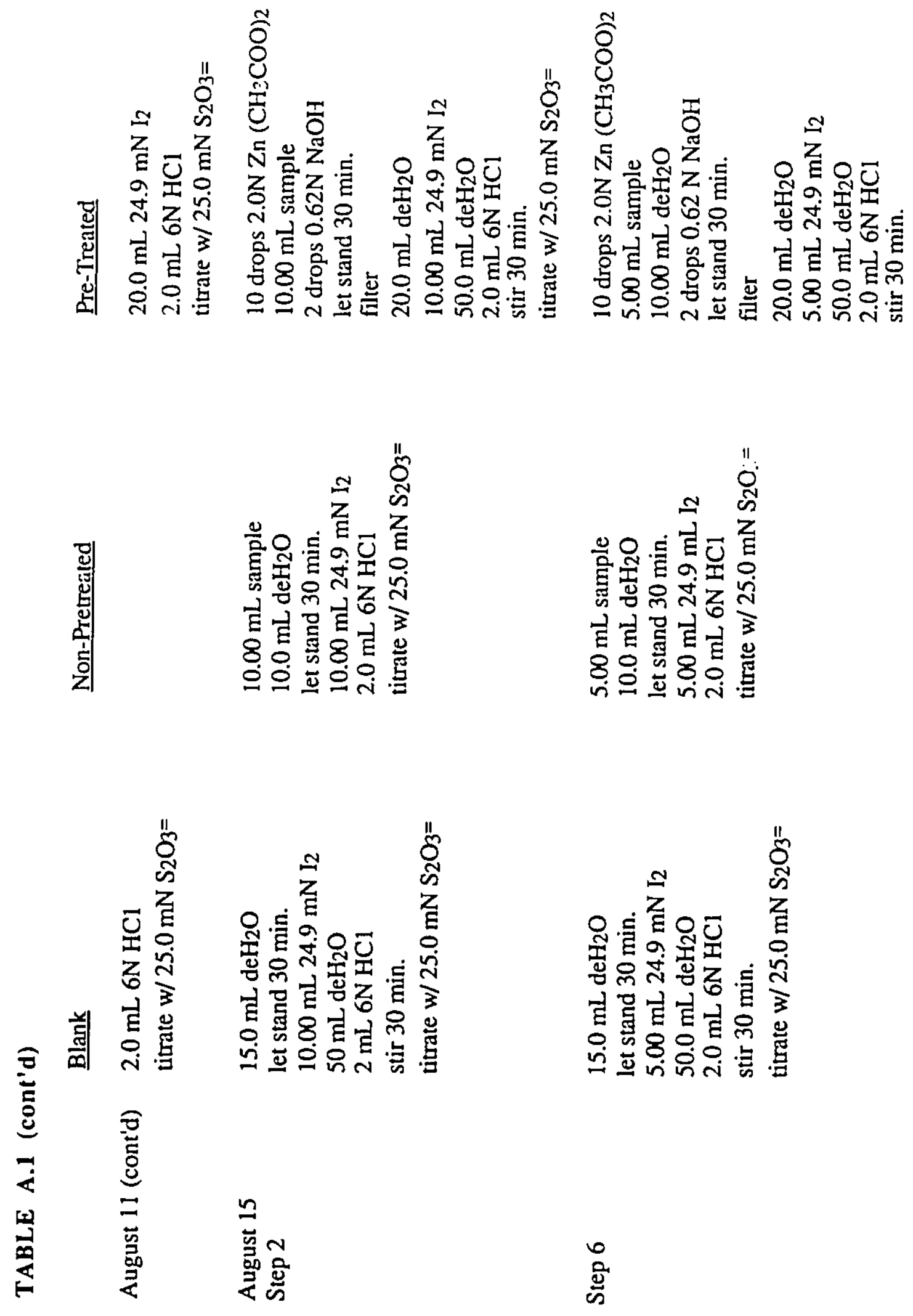

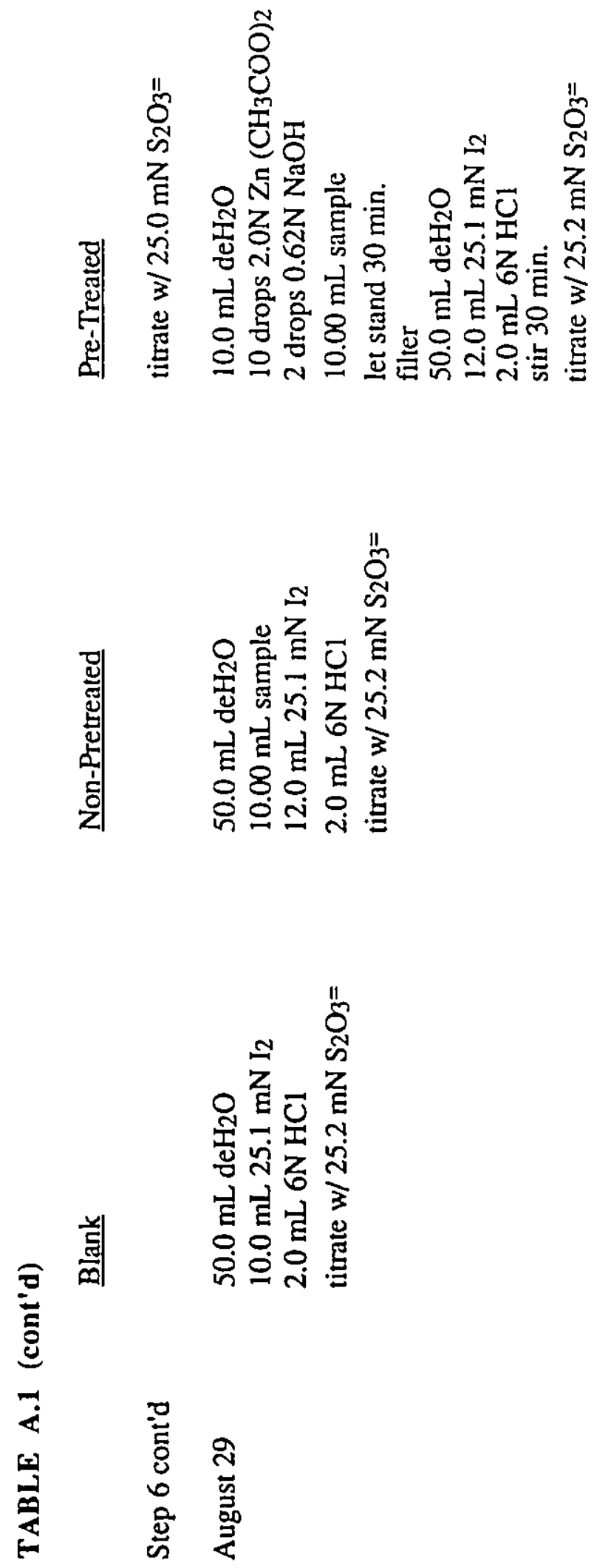


\section{B. Non-Pretreated}

The sulfide sample and $\mathrm{deH}_{2} \mathrm{O}$ were added to a $250 \mathrm{~mL}$ erlenmeyer flask and either titrated without delay or allowed to stand 30 minutes. A quantity of the standard iodine solution and $\mathrm{HCl}$ were added and the mixture was titrated as in section A.2.1.A Blank.

C. Pretreated

Typically, the sulfide sample was added to a $250 \mathrm{~mL}$ erlenmeyer flask to which zinc solution and hydroxide solution had been added. After allowing 30 minutes for precipitation, the solution was filtered through a $42.5 \mathrm{~mm}$ dlameter Whatman's GF/C glass flbre filter in a Buchner funnel. The flask and filter cake were rinsed with 10-20 mL of $\mathrm{deH}_{2} \mathrm{O}$ or $\mathrm{HCl}$ as indicated in Table A.1. The filter paper and filter cake were carefully folded and inserted back into the erlenmeyer flask. Deionized water, standard lodine solution, $H C l$ and a magnetic stir bar were added to the flask. The mixture was titrated either immediately or stirred for 30 minutes as indicated in Table A.1. Titration was performed with standardized thiosulfate solution as indicated in Section A.2.1.A. Blank. The results of five trials of the lodometric method without pretreatment and six trials with pretreatment are shown in Table A.2. On three occasions, the iodometric method without pretreatment gave readings of sulfide greater than the amount added. The coefficient of variation for these trials averaged 0.78 . With pretreatment, the lodometric method gave more accurate readings but precision suffered. Sulfide readings were equal to or less than the quantity of sulfide added to the sample within the experimental limits of uncertainty. Sulfide readings indicating less sulfide than the amount added may have been due to spontaneous sulfide 

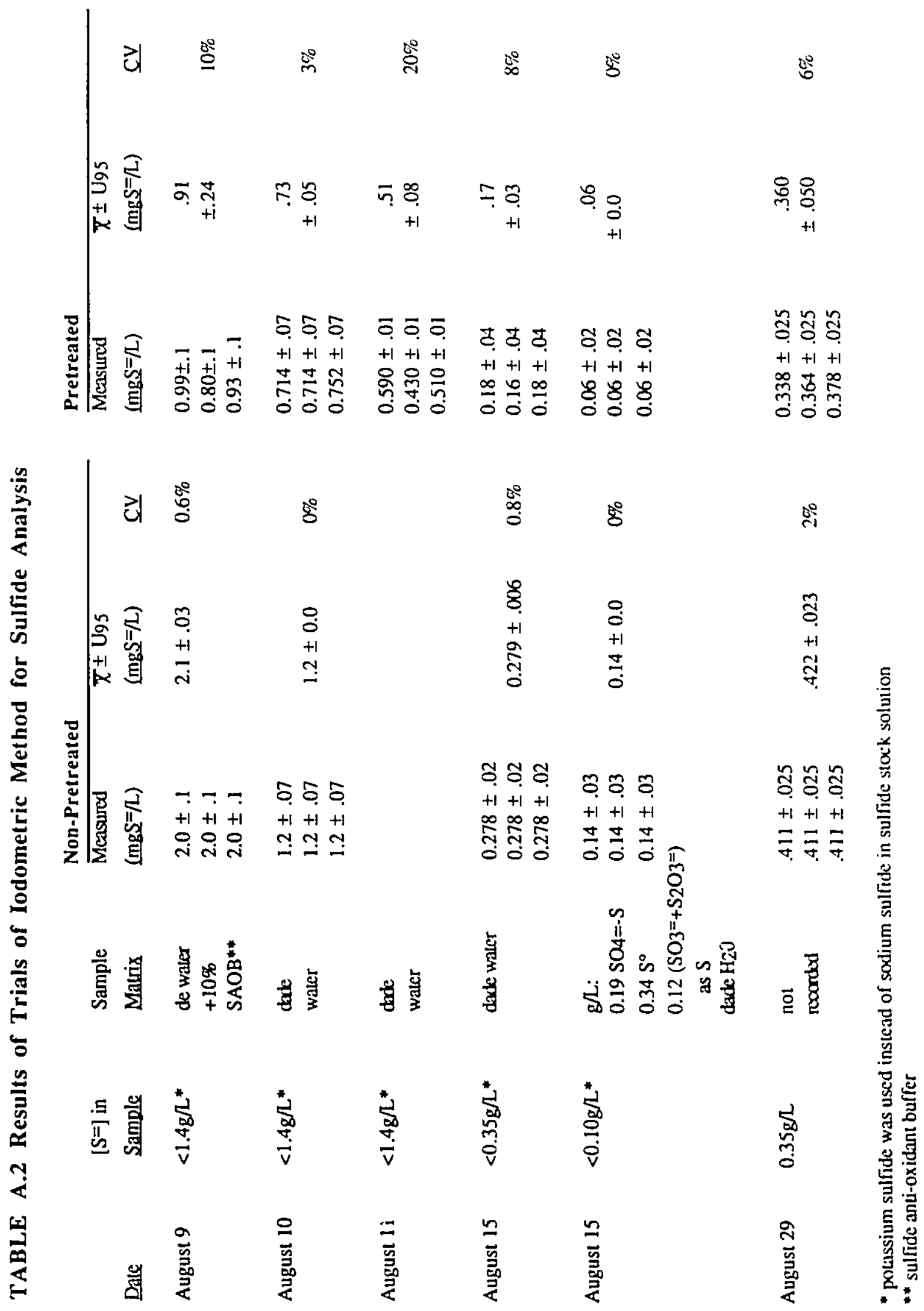
oxidation or degassing of $\mathrm{H}_{2} \mathrm{~S}(\mathrm{~g})$. The coefficient of variation averaged 88 with pretreatment indicating lower precision than the lodometric method without pretreatment.

\section{A.2.2 Potentiometric Method}

In this method aqueous sulfide was complexed with lead to form lead sulfide, a black precipitate. The activity of sulfide in the solution was monitored electrochemically by a silvar/sulfide electrode against a double junction reference electrode. The equivalence point was reached when there was a sudden rise in the potential between the electrodes (Orion,1980). Lead perchlorate $\left(\mathrm{Pb}\left(\mathrm{ClO}_{4}\right)_{3}\right)$ is recommended (Orion,1980; Baumann, 1974) for the standard lead solution but is unacceptable as a primary standard because it is unstable (extremely hygroscoplc). Disodium ethylenediaminetetraacetic acid $\left(\mathrm{Na}_{2} \mathrm{H}_{2} \mathrm{EDTA} \cdot 2 \mathrm{H}_{2} \mathrm{O}\right)$ was dried at $80^{\circ} \mathrm{C}$ to remove superficlal moisture and was stable enough to be used as a primary standard (Skoog et al,,1982). A measured volume of the EDTA solution was titrated with lead perchlorate solution using the electrode combination mentioned above. The volume of lead solution added was plotted against the $\mathrm{mV}$ reading. The point of inflection of this curve was taken as the equivalence point and used to calculate the concentration of the lead solution.

Sulfide ant1-oxidant buffer (SAOB) stock was made up as follows van Gemerden, 1984):

$80 \mathrm{~g} \mathrm{NaOH}$

$67 \mathrm{~g} \mathrm{Na} \mathrm{H}_{2} \mathrm{EDTA} \cdot 2 \mathrm{H}_{2} \mathrm{O}$

$35 \mathrm{~g}$ ascorbic acid make up to $1 \mathrm{~L}$ with $\mathrm{deH}_{2} \mathrm{O}$

After the first trlal, a SAOB stock was made up from the above ingredients 
less the ascorbic acid. Roughly $1.8 \mathrm{~g}$ ascorblc acid and $50.0 \mathrm{~mL}$ SAOB stock were added to the titration beaker lmmedlately before the sulfide sample was plpetted (Table A.3). The function of the ascorbic acid was to remove oxygen from the solution so that the sulfide would not be oxidized. After standing three to four hours, the titration mixture formed a copperbrown layer on the surface indicating oxidation of the ascorbate. The mixture was continuously stirred while being titrated with lead solution. After each addition, about is minute was needed for the drift in the potential to stabilize to less than one $\mathrm{mv} / \mathrm{min}$. Then, the reading was taken. The endpoint was determined by two methods:

\section{A. Calculation}

The $\mathrm{mV}$ reading after each addition of titrant was subtracted from the reading before the addition. This difference (Amv) was divided by the volume of the addition ( $\Delta \mathrm{mL}$ ). The quotient $\mathbf{I m V} / \mathrm{dmL}$ is the slope of the titration curve. The slope is highest at the point of inflection of the titration curve (equivalence point). Thus, the highest $\Delta \mathrm{mv} / \Delta \mathrm{mc}$ value occurs at the end point.

B. Graph

In this method, $\mathrm{mV}$ readings were plotted against volume of titrant added. The slgmoldal curve that resulted was approximated by drawing three straight lines. The line through the initial (lead) part of the titration curve and the line through the tall were approximately parallel. The line In the midale (vertical) part of the graph intersected the two previously drawn lines. The equivalence point was taken as the mid-point of the vertical line between the upper and lower intersection points.

Table A.4 is a summary of the results of eleven trials of the 


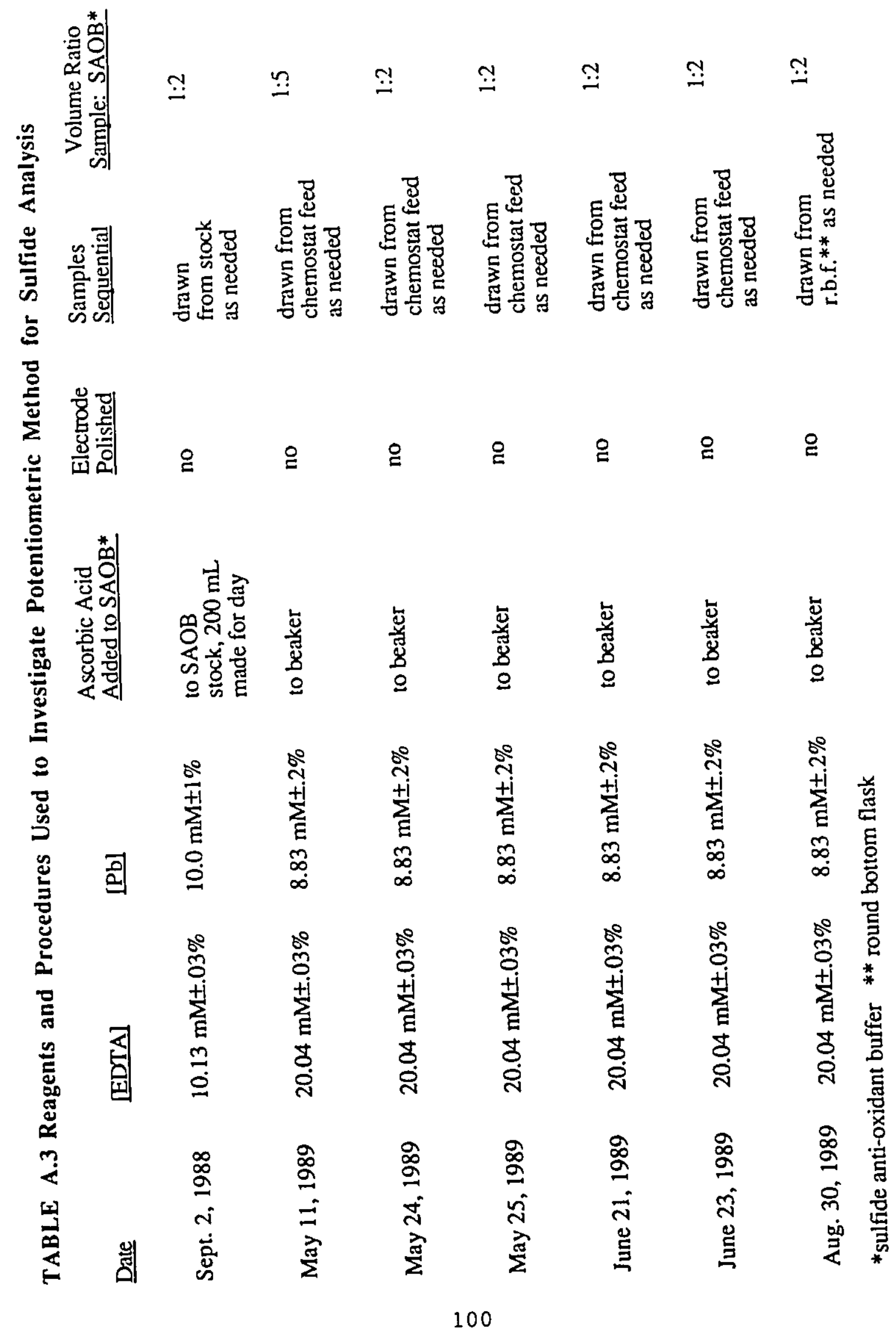




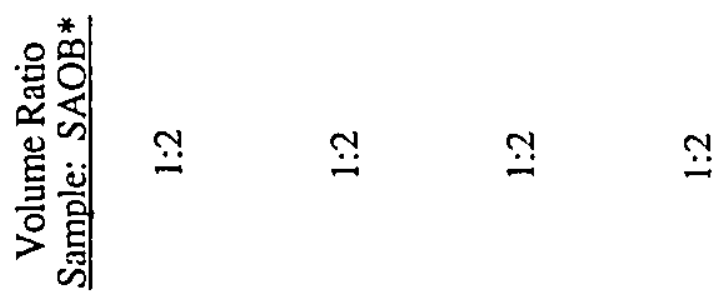

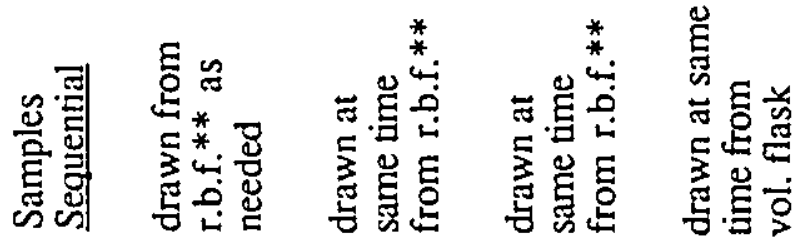

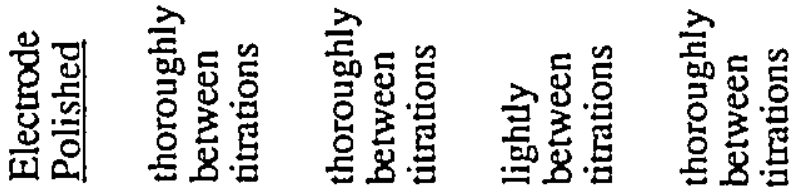

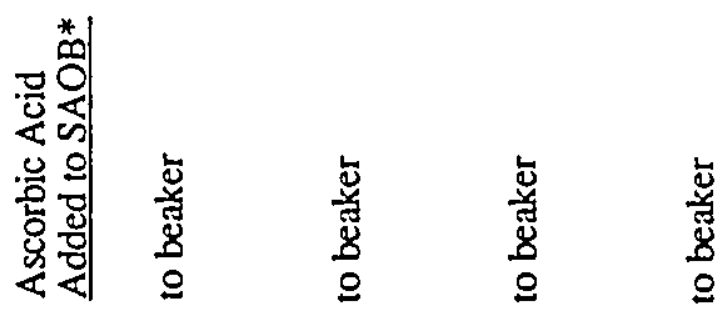

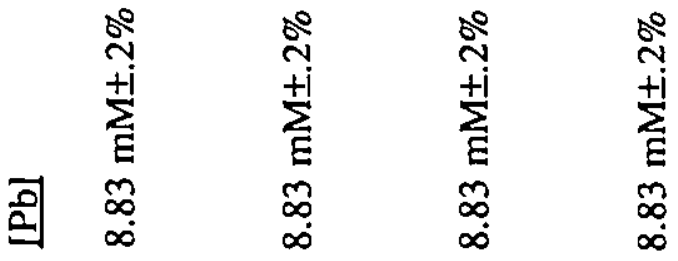

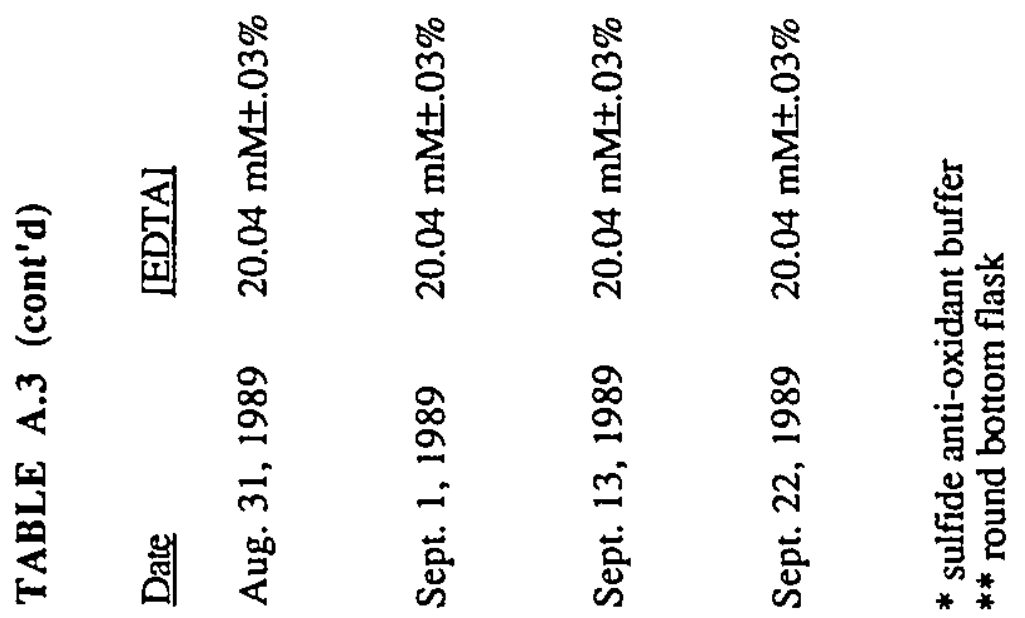




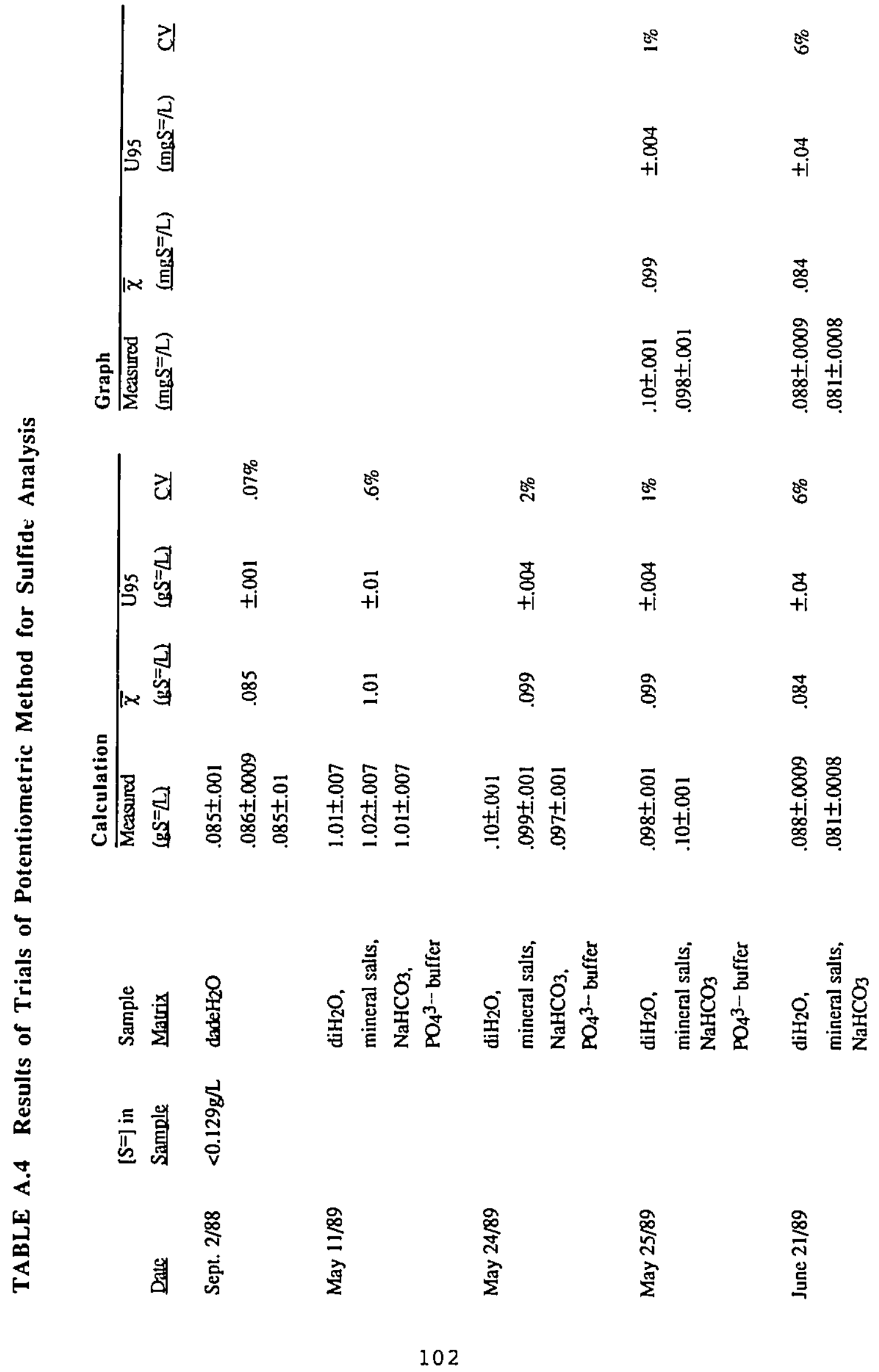



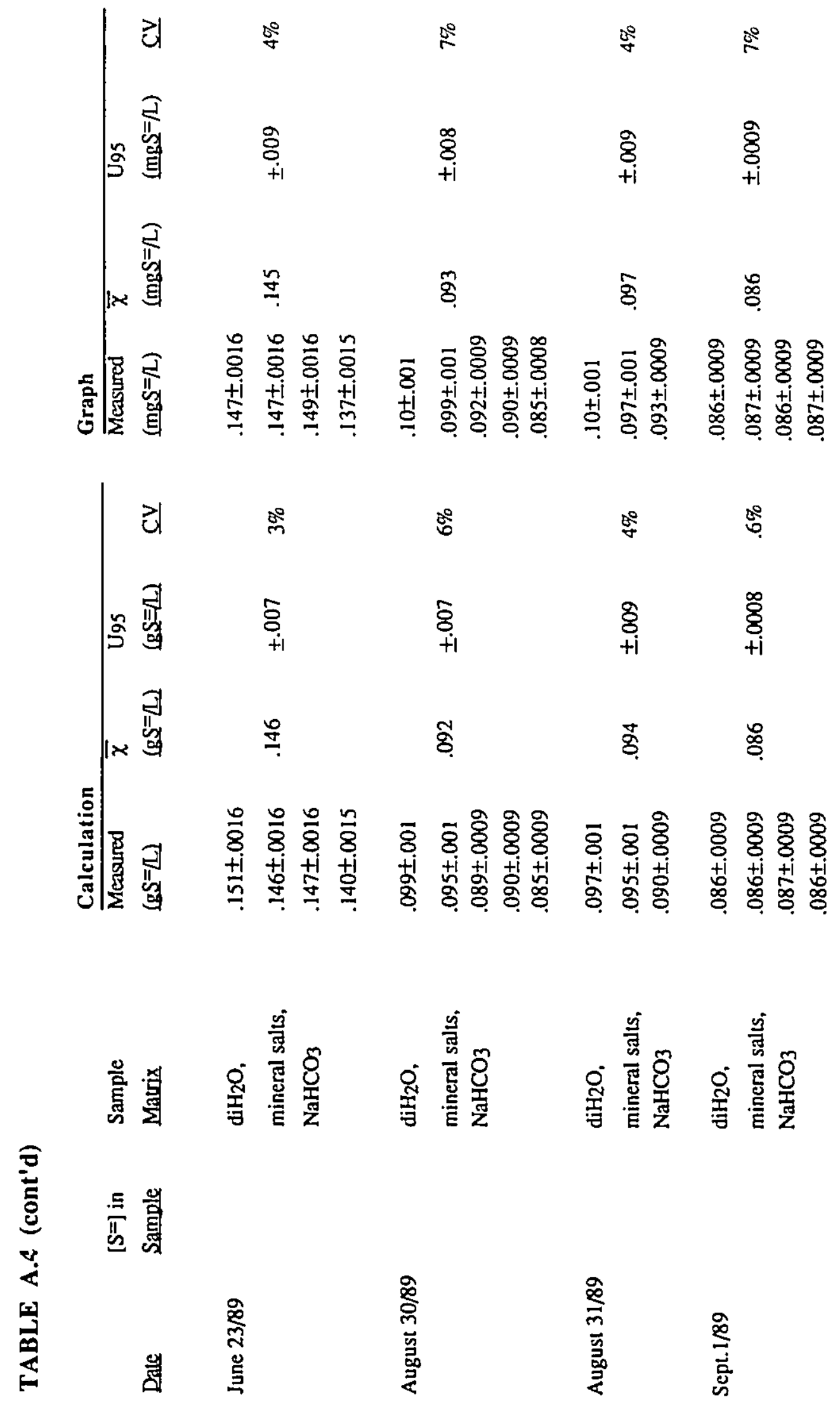

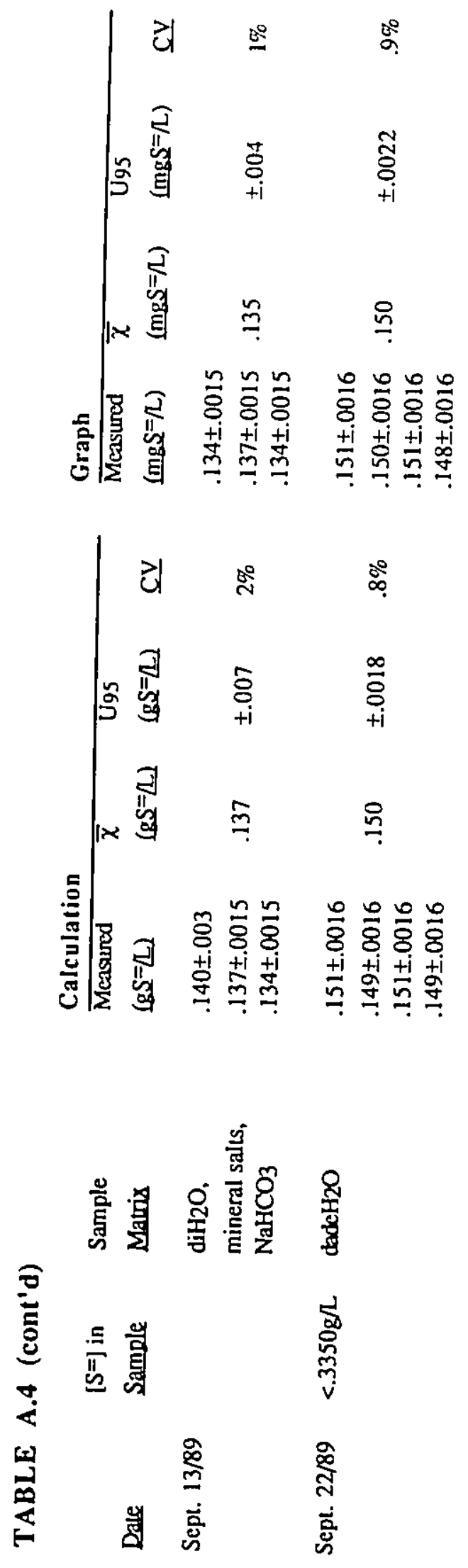
potentiometric method. The average coefficients of variation for the calculation and graphical methods were both $3 \%$ for those trials where both methods wexe used. In addition, the calculation method gave a sulfide concentration that was higher twice, the same 4 times and lower twice of the eight times that both methods were used. There is no signlficant difference in the coefficients of varlation or the average sulfide concentrations between the use of the calculation and graphical methods. Therefore, the calculation method is preferred because: it does not require graphing, it can be done during the titration and, there is no need to titrate much beyond the equivalence point. The use of the calculation method results in a savings of $k$ hour per titration over the graphical method.

In terms of the accuracy of the potentiometric method, in the first and last trials the sulfide concentration was well under the known sample maximum. In terms of precision, the average coefficient of variation for all trials was 28. In trials on August 30 and 31 , where samples were taken as needed from a single round bottom flask, there a decrease in the values of successive readings. This may have been due to oxygen introduced to the flask while sampling or equilibration of $\mathrm{H}_{2} \mathrm{~S}$ between the gas and 11quid phases.

This method is superior in precision to the lodometric method with pretreatment and as such was used to callbrate stock sulfide solutions for the methylene blue method.

\section{A.2.3 Hethylene Blue Method}

Table A.5 compares the reagents used in the Standard Methods' Methylene Blue Method 4500-S2- D. (APHA, 1989) and that reported by Truper 
TABLE A.5 Comparison of Reagents in Methylene Blue Methods of Sulfide Analysis

Truper et al (1964)

$\max . S=($ mmolc $)$

$\mathrm{Zn}\left(\mathrm{CH}_{3} \mathrm{COO}\right)_{2}$ (mmole)

DPD (mmole)

$\mathrm{Fc}^{3+}($ mmole $)$

$\mathrm{H}_{2} \mathrm{SO}_{4}(\mathrm{~mL})$
.0039

2.2

.085

19

2.0
APHA (1985)

.058

.11

17

3 
et al., (1964). In both methods, sulfide reacts quantitatively with excess dimethyl-p-phenylenediamine (DPD) to make leuco-methylene blue. This compound reacts with ferric ion to form methylene blue and ferrous ion. In the latter method, the sulfide sample is added to a zinc acetate solution to precipitate zinc sulfide. This step preserves the sulfide content of the sample until DPD can be added. Truper's method requires less than $1 \mathrm{~mL}$ of sample whereas the APHA method requires $7.5 \mathrm{~mL}$.

In Truper's method $20 \mathrm{~mL}$ of $28 \mathrm{Zn}\left(\mathrm{CH}_{3} \mathrm{CO}\right)_{2}$ solution was measured into a $100.00 \mathrm{~mL}$ volumetric flask. A $1 \mathrm{~mL}$ syringe with graduations of $0.01 \mathrm{~mL}$ and a $70 \mathrm{~mm}$ needle was used to draw sulfide samples. Then, the syringe was inverted into the volumetric flask so that the distance between the end of the needle and the zinc solution was less than ten mm. The sample $(0.1$ to $0.95 \mathrm{~mL})$ then forced out from the syringe so that it inmediately contacted the zinc solution and was stablilzed. A plpette was used to add $10.00 \mathrm{~mL}$ of 0.28 dimethyl-p-phenylenediamine sulfate in $20 \% \mathrm{H}_{2} \mathrm{SO}_{4}$ and $0.50 \mathrm{r}$. $\mathrm{L}$ of 108 ferric ammonium sulfate in $28 \mathrm{H}_{2} \mathrm{SO}_{4}$. The flask was filled to the mark with distilled water, capped and inverted twice. A minimum of 30 minutes were required for the colour to develop (Figure A.1). After this time the absorbance was measured spectrophotometrically at $670 \mathrm{~nm}$ against a diHzO blank. Sulfide samples of $0,0.1,0.2,0.3,0.4$ and $0.5 \mathrm{~mL}$ were analyzed by the methylene blue method on a day on which the sulfide stock solution was analyzed potentiometrically. Sulfide concentration in the curette was calculated (Table A.6) and a linear regression was performed (Figure A.2). This correlation was used to determine the sulfide stock concentration in further tests in Section A.2.3. 


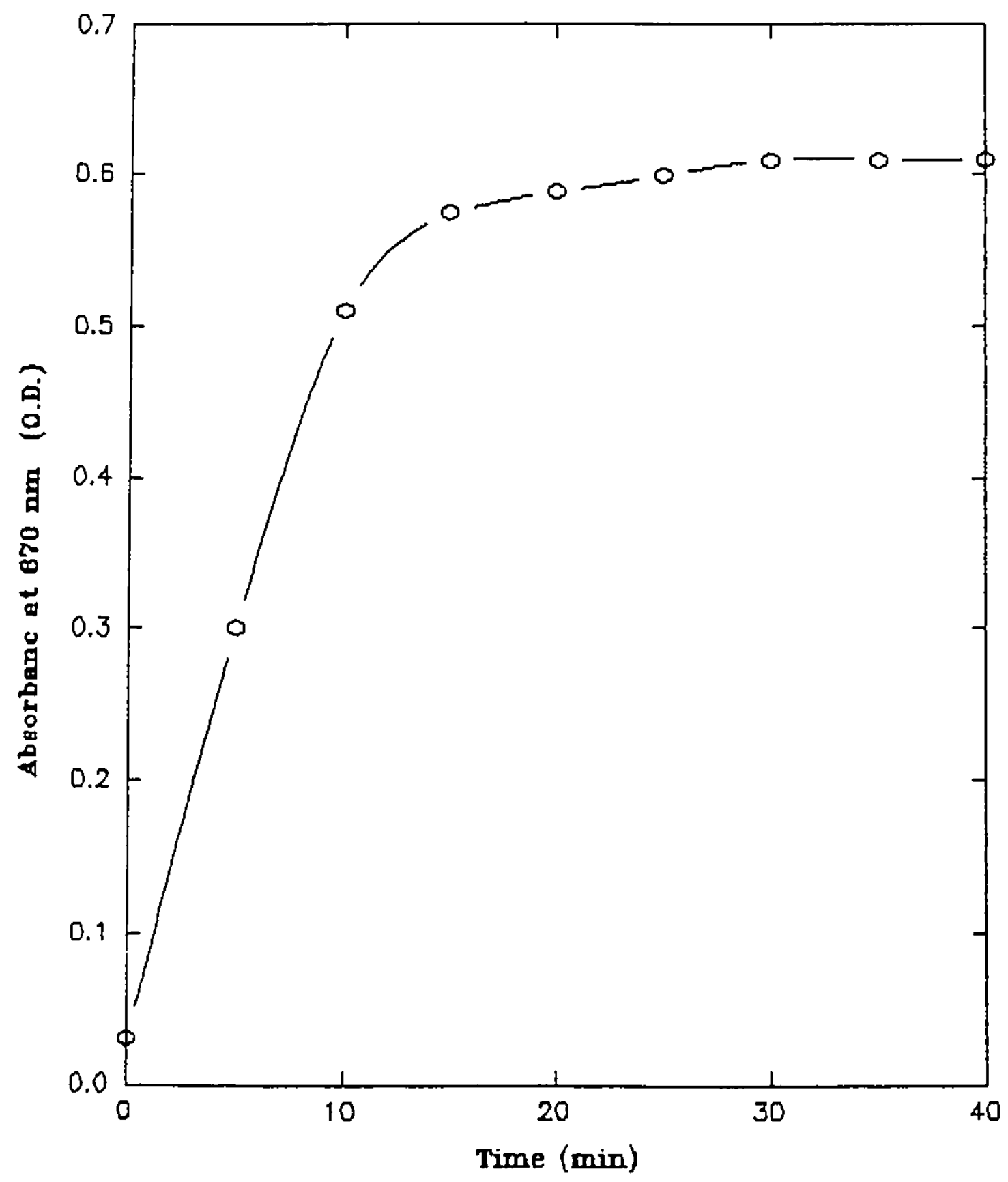

FIGURE A.1 Colour Development in Truper's Methylene Blue Method of Sulfide Analysis 
TABLE A.6 Calibration of Truper's Methylene Blue Method of Sulfide Analysis Without Added Sulfur Compounds

$\begin{array}{cccc}\begin{array}{c}\text { Flask } \\ \text { Ne. }\end{array} & \begin{array}{c}\text { Volume } S=S t o c k \\ {[150 \pm 1.8 \mathrm{mg} / \mathrm{L}]} \\ (\mathrm{mL})\end{array} & \begin{array}{c}{[S=] \text { in }} \\ \text { Cuvette } \\ (\mathrm{mg} / \mathrm{L})\end{array} & \begin{array}{c}\text { Absorbance, } \\ \text { average of } 3 \text { readings } \\ \text { (O.D.670) }\end{array} \\ 1 & 0 & 0 & .003 \\ 2 & 0 & .150 & .149 \\ 3 & .100 & .300 & .338 \\ 4 & .200 & .450 & .517 \\ 5 & .300 & .600 & .680 \\ 6 & .400 & .750 & .860\end{array}$




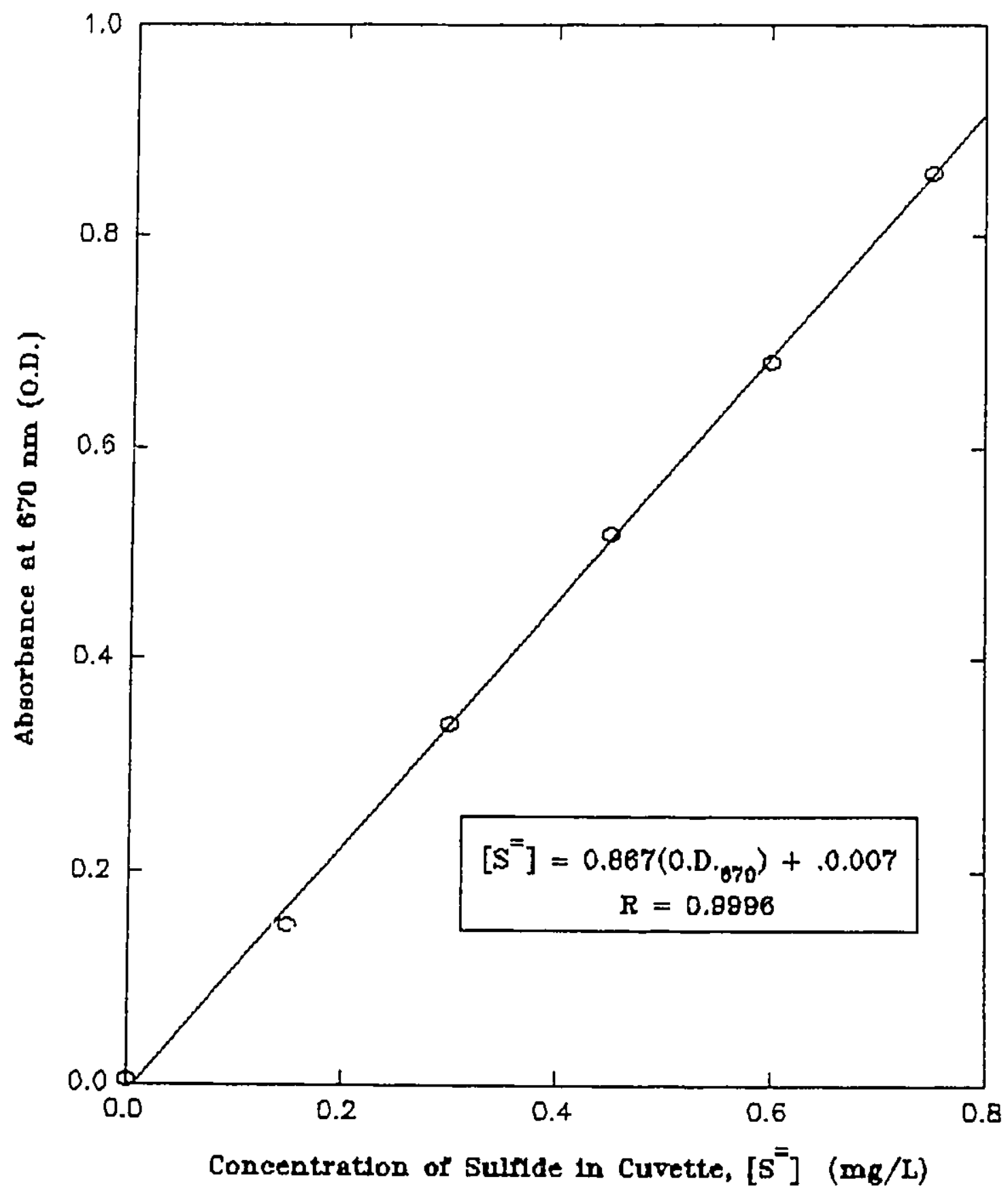

FIGURE A.2 Calibration of Truper's Methylene Blue Method of Sulfide Analysis Without Added Sulfur Compounds 
To determine the eifects of varlous interferences on the methylene blue method of measuring sulfide, stock solutions of sulfide, sulfur, and sulfate were combined in various proportions and sulfide was measured. In addition, repetitions of sulfide tests at the same concentration were performed to establish the uncertainty of the sulfide test. The results are shown in Table A.7.

The results of all methylene blue sulfide tests shown in Table A.7 were plotted in Figure A.3. The data were consldered to be from the same population. The line of best fit and the $95 \%$ confidence limit envelope are shown. The widths of this envelope at the lowest and highest in-range values were measured. The greatest width value was divided by two and used as the uncertainty of the concentration in the cuvette.

\section{A.3 Blemental Surfur}

\section{A.3.1 Ethanol Hethod}

Cork (1978) has described the method of Schmidt and Kamen (1970) where an aqueous sample was diluted 1:2 with 958 ethanol. The sample was centrifuged and the absorbance of the supernatant measured at $264 \mathrm{~nm}$, varied linearly with the sulfur concentration. Maka (1986) has referred to the technique of van Gemerden (1968) where the aqueous sample was diluted 1:40 with 958 ethanol and refluxed for two hours. Subsequently, the ethanol mixture was centrifuged at $3000 \mathrm{rpm}$ (clinical centrifuge) for 30 minutes. The absorbance of the supernatant was measured at $264 \mathrm{~nm}$ against a 95\% ethanol blank. Van Gemerden (1968) measured absorbance at $260 \mathrm{~nm}$.

Initially, a callbration curve developed by diluting a stock solution of roll formed elemental sulfur in 958 ethanol and measuring the 


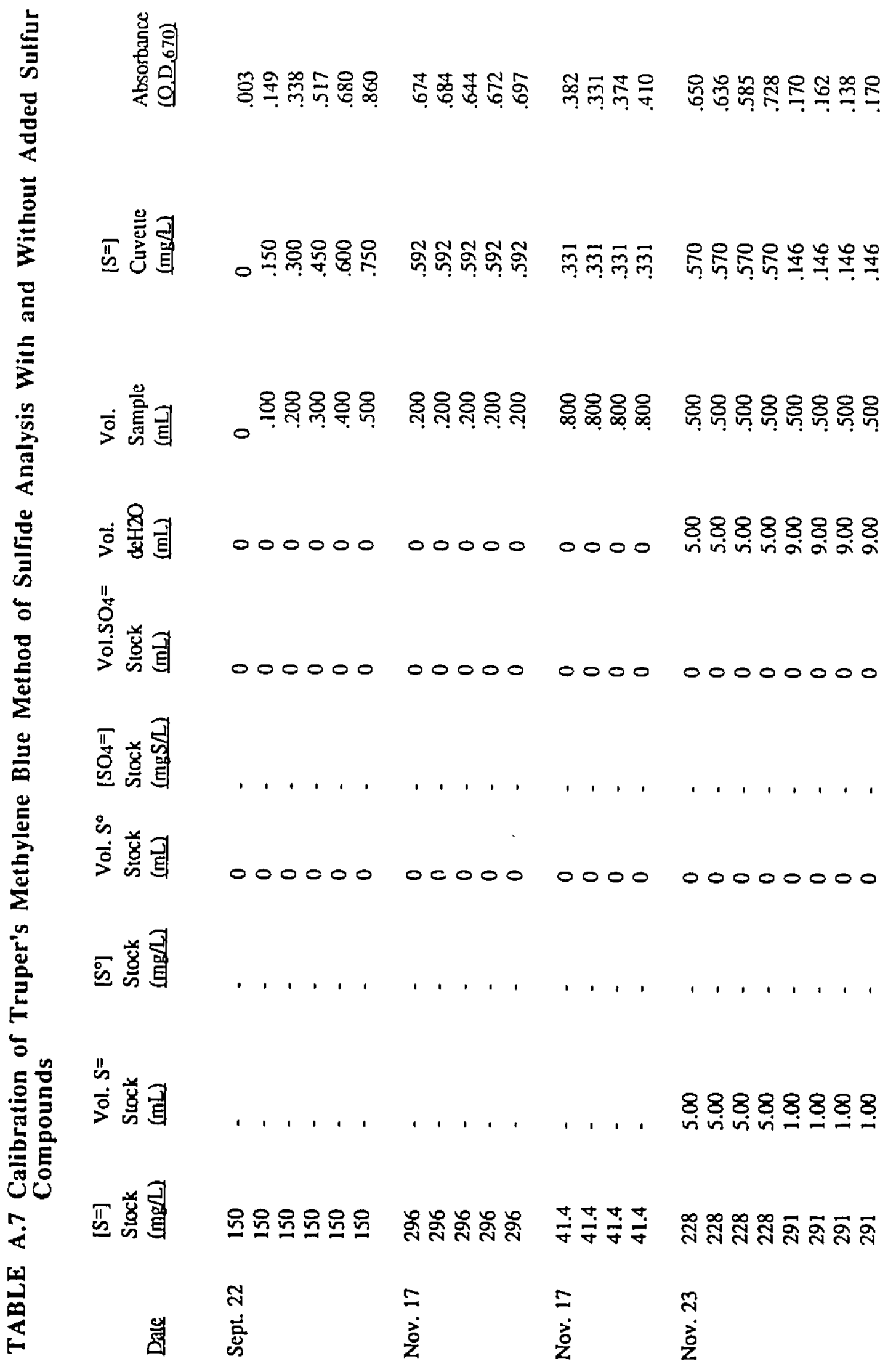




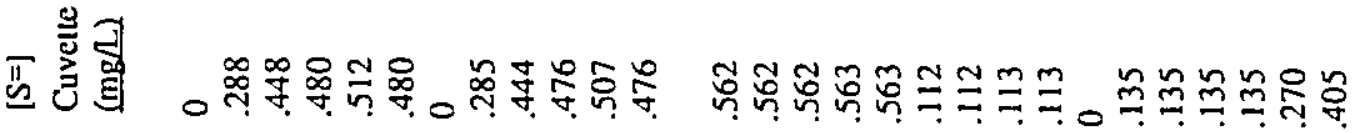

j

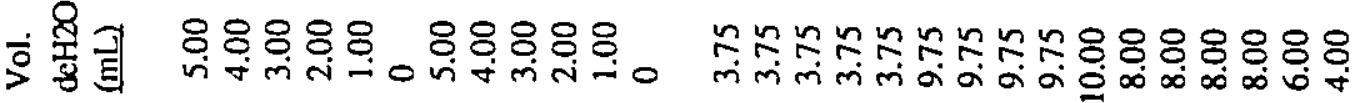

¿ั

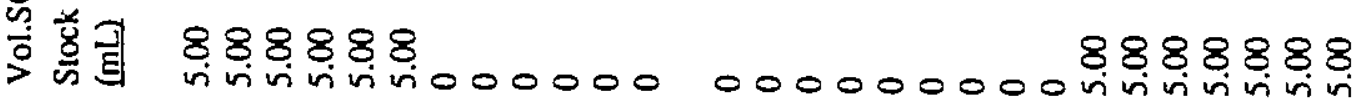

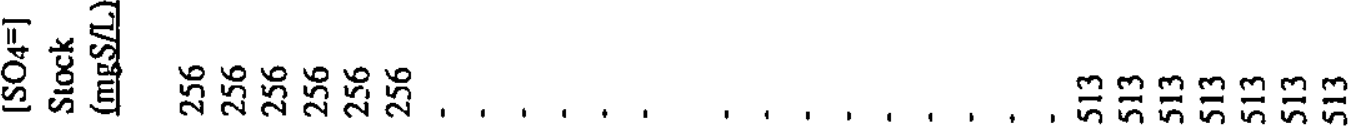

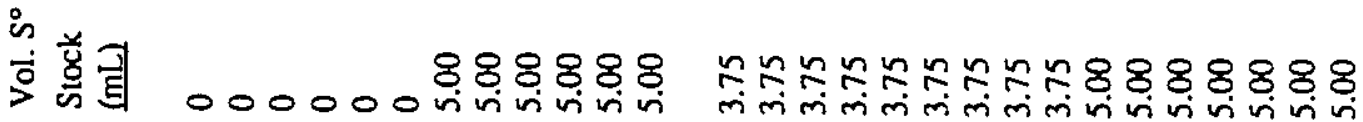

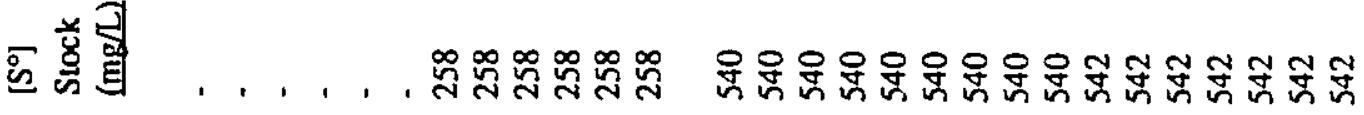

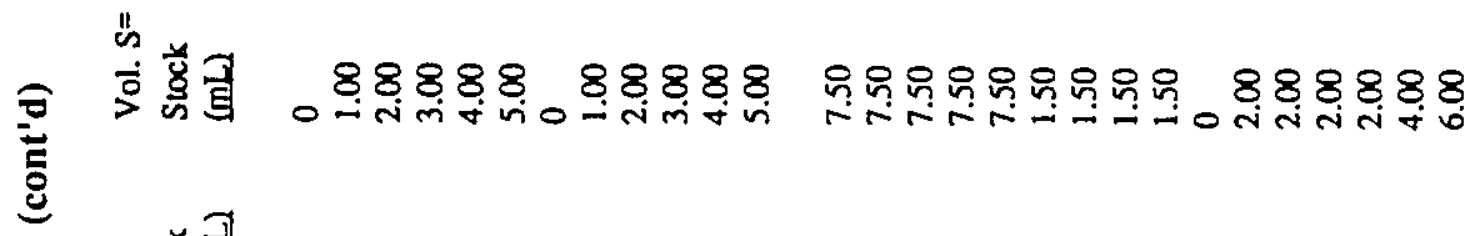

믄

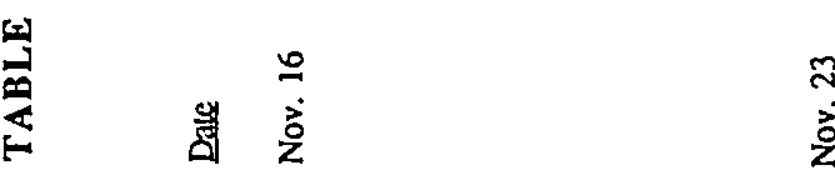




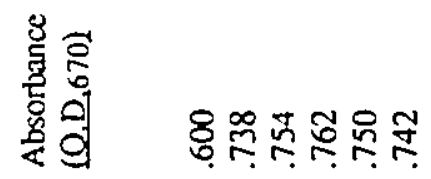

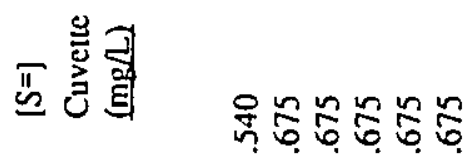

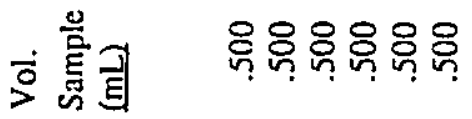

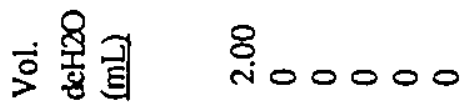

苋兽园 888888

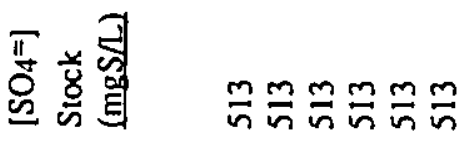

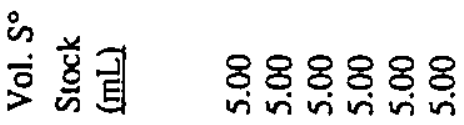

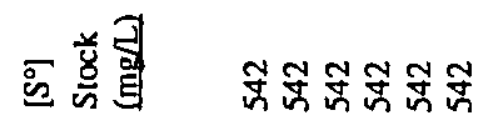

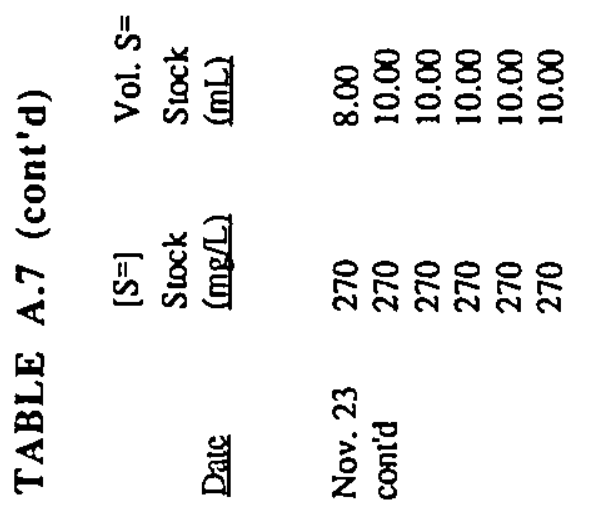




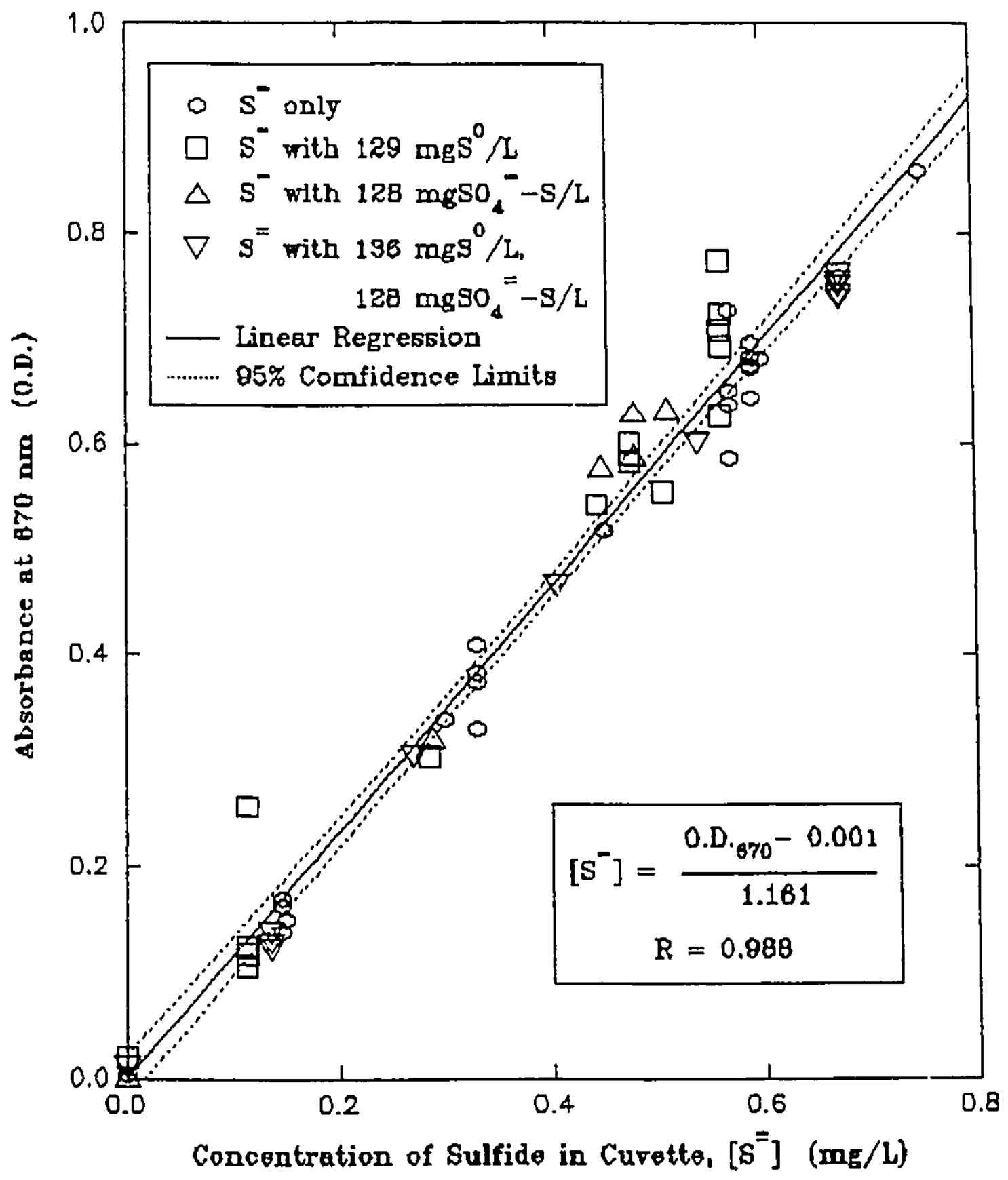

FIGURE A.3 Calibration of Truper's Methylene Blue Method of Sulfide Anelysis With and Without Added Sulfur Compounds 
absorbance at $262 \mathrm{~nm}$. The calibration curve was linear in the range 0 to $33 \mathrm{mgS} / \mathrm{L}$ with a correlation coefficient of 0.9994 . A mixture of known amounts of potassium sulfide stock solution, $\mathrm{Na}_{2} \mathrm{SO}_{4}, \mathrm{Na}_{2} \mathrm{SO}_{3}, \mathrm{Na}_{2} \mathrm{~S}_{2} \mathrm{O}_{3}$ and elemental sulfur in $\mathrm{deH}_{2} \mathrm{O}$ was filtered through Whatman's $\mathrm{GF} / \mathrm{C}$ filter paper. The fllter paper was transferred to an erlenmeyer flask and refluxed in 958 ethanol for 2 hours. The heated ethanol was transferred to a volumetric flask and made up to volume with $95 \%$ ethanol. The absorbance of this solution at $262 \mathrm{~nm}$ yielded a sulfur content equal to 988 of the amount added. The sulfur added was not finely dispersed in the aqueous mixture but remained in a layer on top. Thus a sample from the bulk liquid would give a false indication of the amount of sulfur present. Also, sulfur produced by bacteria may be more finely dispersed and may not be filterable. Thus, a second test of this sulfur method was performed using a fine suspension of sulfur in a sulfide/sulfate solution.

A second calibration of the ethanol method was performed this time measuring absorbance at $264 \mathrm{~nm}$ (Figure A.4).

A second test was performed to determine the effects of other sulfur species. Stock solutions of $\mathrm{Na}_{2} \mathrm{~S} \cdot 9 \mathrm{H}_{2} \mathrm{O}$ and $\mathrm{Na}_{2} \mathrm{SO}$, were made in $\mathrm{deH}_{2} \mathrm{O}$. The solubility of $\mathrm{s}^{\circ}$ in 958 ethanol $1 \mathrm{~s} 1.4 \mathrm{~g} / \mathrm{L}$ at reflux temperature and 0.3 $\mathrm{g} / \mathrm{L}$ at room temperature. In order to achieve a high sulfur content in the sample but minimize the ethanol content so as to best simulate a reactor sample, a sulfur colloidal solution was made (see Section A.1.1). Twentyfive $(25.00) \mathrm{mL}$ allquots of all stock solutions were combined in test tubes. A $10.00 \mathrm{~mL}$ sample taken from each combination and stock solution. The sample wes added to approximately $65 \mathrm{~mL}$ of 958 ethanol and refluxed for 2 hours. After cooling, the contents of the reflux vessel 


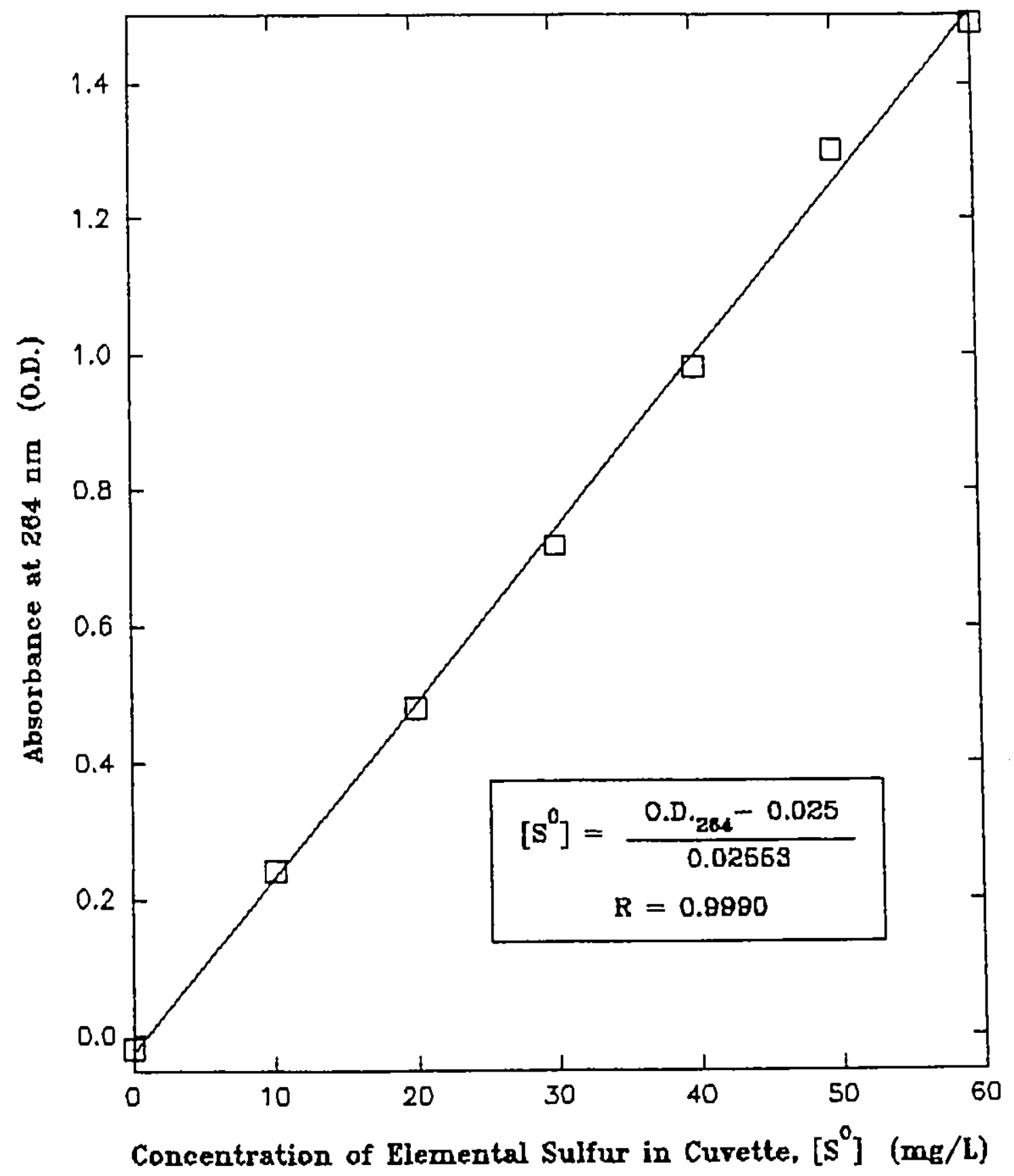

FIGURE A.4 Calibration of Ethanol Method of Elemental Sulfur Analysis 
was poured into a $100.00 \mathrm{~mL}$ volumetric flask and made up to the mark with 958 ethanol. The absorbance of this solution was measured at $264 \mathrm{~nm}$ and converted to sulfur concentration using the callbration curve developed prevlously (Figure A.4). The results of this study are shown in Table A. 8 . Sulfur recovery was $78 \%$ without interference and dropped to $14 \%$ in the presence of sulfide. The samples containing sulfide and elemental sulfur exhibited a yellow colour owing to the formation of polysulfides $\left(S_{2}{ }^{2-}\right.$ to $\mathrm{S}_{0}^{2-}$ ). Polysulfides have a light absorption peak at 285 to $290 \mathrm{~nm}$ (Chen,1974) in water and presumably this shift occurs in ethanol as well, decreasing the sulfur peak at $264 \mathrm{~nm}$. On acidification, solutions of polysulfldes form $\mathrm{H}_{2} \mathrm{~S}$, free sulfur (milk of sulfur) in white colloidal form and small amounts of hydrogen polysulfides (Chen, 1974).

The acidification of samples by hydrochloric acid was tested as a means of removing $\mathrm{H}_{2} \mathrm{~S}(\mathrm{~g})$. Aliquots of a $\mathrm{Na}_{2} \mathrm{~S}$ solution and a sulfur colloidal solution were added to an erlermeyer flask (Table A.9). The effects of $\mathrm{HCl}$ on sulfide are shown in Flgure A.5. The effect of the addition of sulfide to the sulfur colloidal solution was confirmed. The yellow colour of the sulfide/sulfur mixture confirmed the presence of polysulfides. The addition of $\mathrm{HCl}$ turned solutions from cloudy to clear but the colour (white or yellow) was unchanged. The acidifled sulfide/sulfur combination gave a higher than normal absorption at $264 \mathrm{~nm}$. At $\mathrm{pH}<0$ the formation of elemental sulfur is favoured in oxidizing environments (Chen, 1974). This may be the reason for the high absorbance. It was concluded that sulfur cannot be measured in the presence of sulfide by the ethanol method without severe modification of the method. 


\section{TABLE A. 8 Results of Second Test of Ethanol Method of Elemental}

Sulfur Analysis With Added Sulfur Compounds

Stock

Solutions

Combined

$\mathrm{S}^{\circ}$

$\mathrm{SO} 4=$

$\mathrm{S}=+\mathrm{S}^{\circ}$

$\mathrm{S}=+\mathrm{SO}_{4}=$

$\mathrm{S}^{\circ}+\mathrm{SO}_{4}=$

$\mathrm{S}=+\mathrm{S}^{\circ}+\mathrm{SO}_{4}=$
Matrix

$123 \mathrm{mgS}=/ \mathrm{L}$

$128 \mathrm{mg} \mathrm{SO} 4=-\mathrm{S} / \mathrm{L}$

$62 \mathrm{mg} S=/ \mathrm{L}$

$62 \mathrm{mg} \mathrm{S}=/ \mathrm{L}$

$64 \mathrm{mg} \mathrm{SO} 4=-\mathrm{S} / \mathrm{L}$

$64 \mathrm{mg} \mathrm{SO} 4=-\mathrm{S} / \mathrm{L}$

$41 \mathrm{mg} \mathrm{S}=\mathrm{S} / \mathrm{L}$

$43 \mathrm{mg} \mathrm{SO} 4=-\mathrm{S} / \mathrm{L}$
$\left[\mathrm{S}^{\circ}\right]$ Added

(mg/L)

$\left[S^{\circ}\right]$ Detected (mg/L)

$\begin{array}{rr}0 & 11 \\ 129 & 100 \\ 0 & 5 \\ 64 & 9 \\ 0 & 10 \\ 64 & \\ 43 & 36\end{array}$




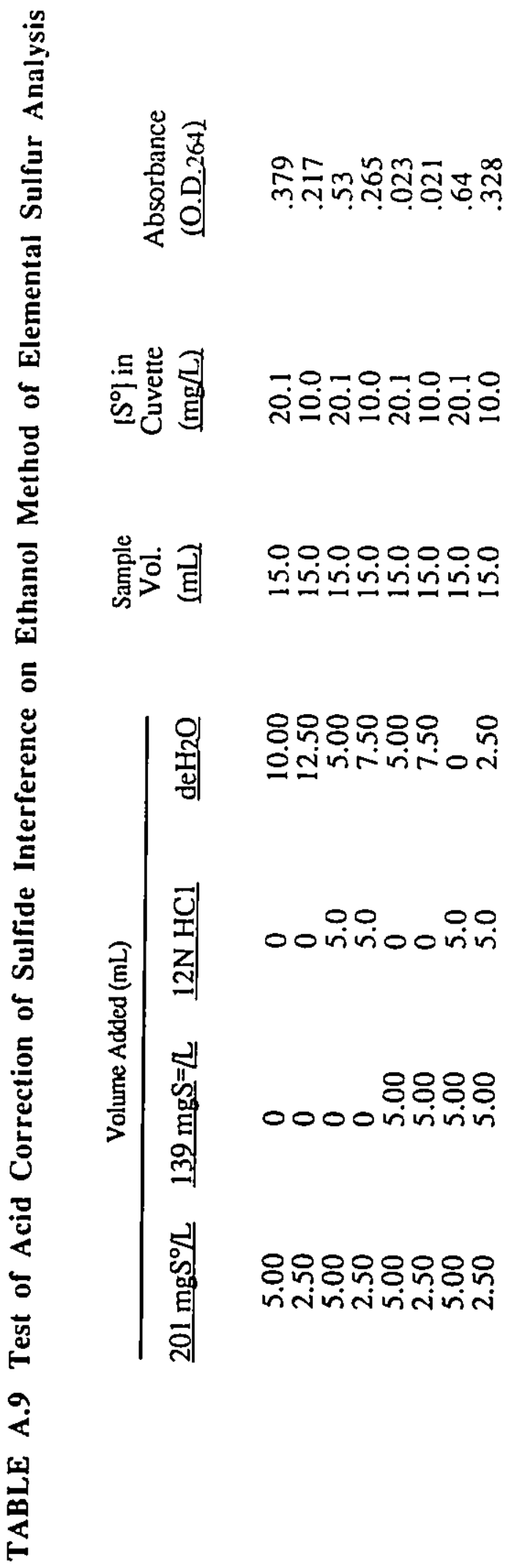




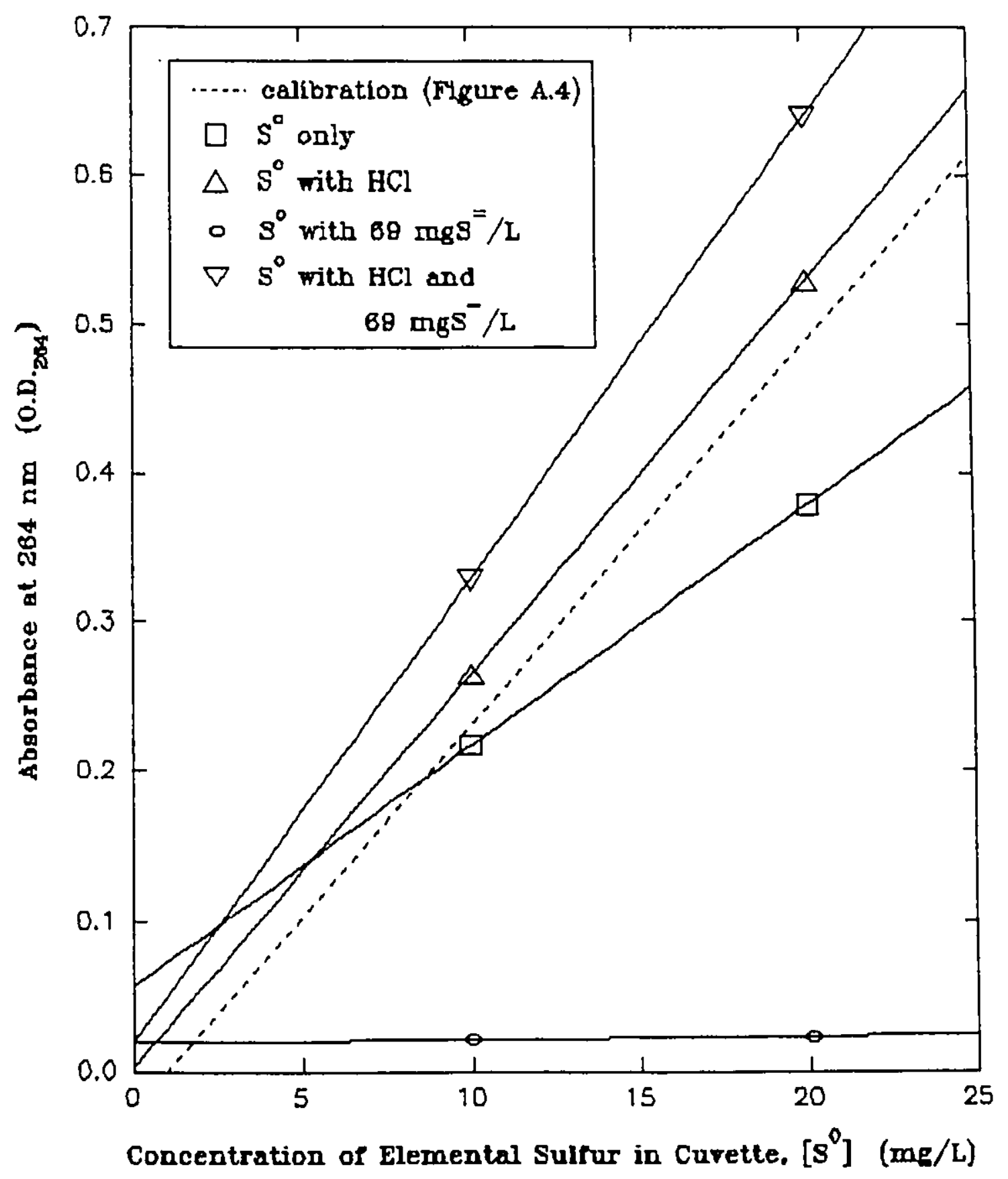

FIGURE A.5 Test of Acid Correction of Sulfide Interference on Ethanol Method of Elemental Sulfur Analysis 


\section{A.3.2 Cyanide Hethod}

The colorimetric method of Bartlett et al.(1954) measures elemental sulfur dissolved in hydrocarbons. In acetone solution, elemental sulfur reacts quantitatively with cyanide ion to yield thiocyanate ion ( $\left.\operatorname{CSN}^{-}\right)$. Thlocyanate can be measured colorimetrically by the addition of ferric chloride. A calibration curve was developed using a stock solution of elemental sulfur in petroleum ether (Figure A.6).

Bartlett's method was modified to extract sulfur from aqueous solutions. A sulfur colloidal suspension was used in the sulfide and sulfate calibrations to confirm or deny sulfur interference. In preliminary calibrations of the cyanide method, erroneous indications of sulfur resulted, presumably because of the inhomogeneity of the colloidal solution. For callbration, a stock solution of elemental sulfur in ethanol was made by refluxing recrystallized (in benzene) elemental sulfur in $95 \%$ ethanol for two hours. After some cooling, the solution was poured into a volumetric flask and made up to the mark with $95 \%$ ethanol.

Combinations of sulfur, sulflde and sulfate stock were added directly to a $250 \mathrm{~mL}$ erlenmeyer flask with a $24 / 40$ ground glass joint. The total volume of stock additions was made up to $10.0 \mathrm{~mL}$ with $\mathrm{deH}_{2} \mathrm{O}$ (Table A.10). Exactly $40.0 \mathrm{~mL}$ of $\mathrm{HgCl}_{2}$ solution $\left(25.5-26.0 \mathrm{~g} \mathrm{HgCl}_{2}\right.$, $25.3-25.8 \mathrm{~g} \mathrm{KCl}$ in $1 \mathrm{~L} \mathrm{deH}_{2} \mathrm{O}$ ), a teflon-coated magnetic stir bar and 20.0 mL of 35-60 petroleum ether were added to the flask which was capped with a ground glass or teflon plug and sealed with parafilm. The mixture was stirred thoroughly for at least 45 minutes to extract sulfur into the organic phase. The upper layer was decanted into a test tube or $25 \mathrm{~mL}$ graduated cylinder so that a plpette could be used to transfer $5.00 \mathrm{~mL}$ of 


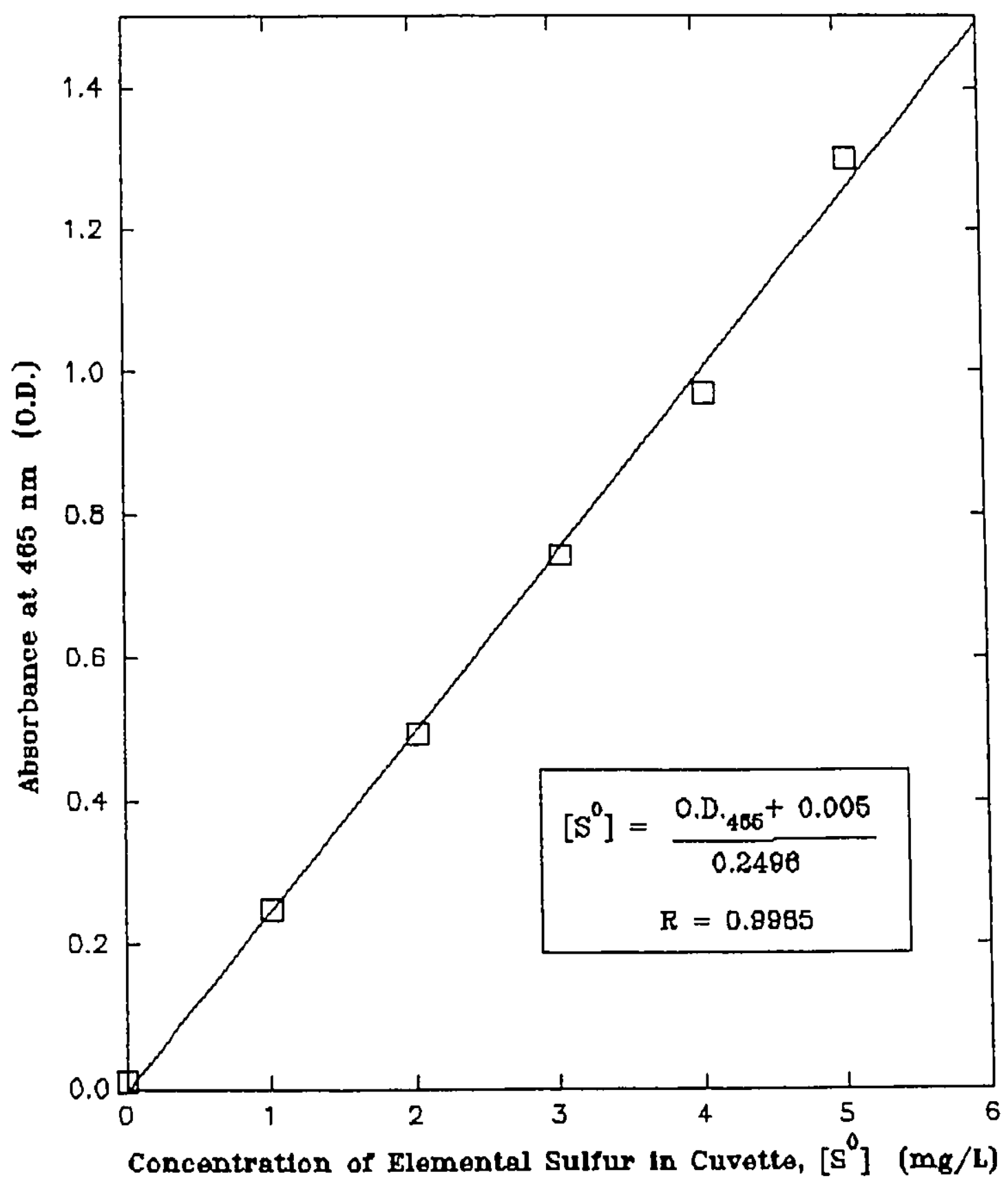

FIGURE A.6 Celibration of Bertlett's Cyanide Method of Elemental Sulfur Analysis 


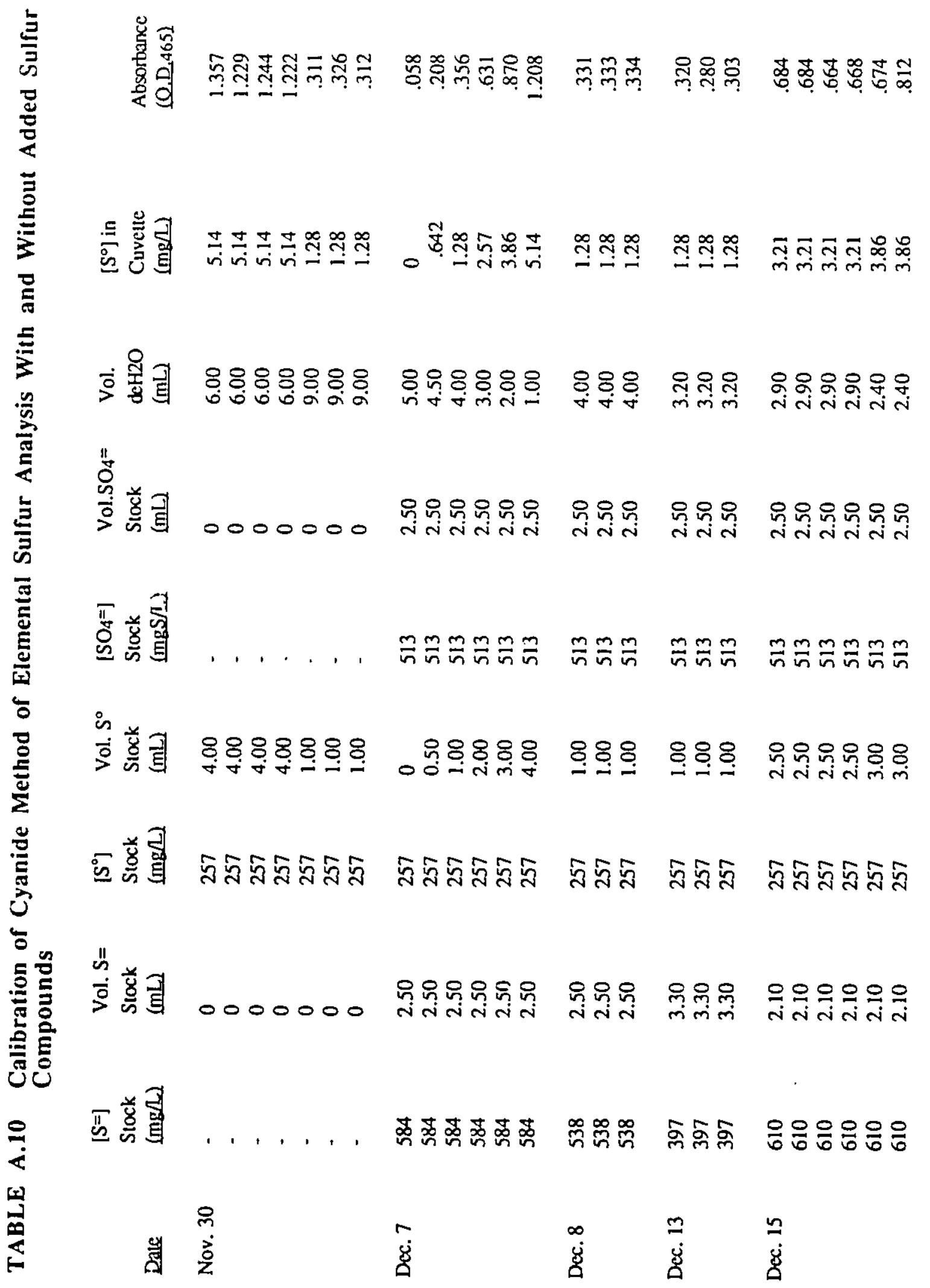


the petroleum ether to a $25.00 \mathrm{~mL}$ volumetric flask. Then, $15.0 \mathrm{~mL}$ of Naan solution ( $1.0 \mathrm{~g} \mathrm{NaCN} / \mathrm{L}$ in $58 \mathrm{deH}_{2} \mathrm{O}$ in ACS grade acetone) was added to the flask. The solution was made up to the mark with $58 \mathrm{deH}_{2} \mathrm{O}$ in acetone and inverted twice. Exactly $5.00 \mathrm{mc}$ of this solution was plpetted into a test tube to which $5.00 \mathrm{~mL}$ of FeCl, solution $14.0 \mathrm{~g} \mathrm{FeCl}_{3} \cdot 6 \mathrm{H}_{2} \mathrm{O} / \mathrm{L}$ in $58 \mathrm{deH}_{2} \mathrm{O}$ in acetone) was added. The absorbance at $465 \mathrm{~nm}$ was measured immediately against a mixture of $5.00 \mathrm{~mL}$ of the $\mathrm{FeCl}$, solution and $5.00 \mathrm{~mL}$ of $58 \mathrm{deH}_{2} \mathrm{O}$ in acetone. The absorbance was plotted agalnst concentration of sulfur In the cuvette in Figure A.7. The line of best fit and the $95 \%$ confidence limit envelope are shown. The widths of this envelope at the lowest and highest in-range values were measured. The greatest width value was divided by two and used as the uncertainty of the concentration in the cuvette. Due to the large range in uncertainty in this calibration, measures of sulfur were performed in triplicate.

\section{A.1 Sulfate}

Standard Methods 4500-SO42- E. (APHA, 1985) describes the turbidimetric method wherein sulfate ion is precipitated in a hydrochloric acid medium with barium chloride $\left(\mathrm{BaCl}_{2}\right)$ so as to form barlum sulfate crystals of uniform size. The turbidity of the precipitated solution was found to be linear with the concentration of the sulfate in the cuvette (Figure A.8). Turbldity mearsurements were made in nephelometric turbidity units with a Hach model 43900 Ratio/XR Turbidimeter.

The presence of sulfide and elemental sulfur in the sample caused a falsely high reading of turbidity even though the sample was centrifuged at $3000 \mathrm{rpm}$ for 5 minutes to settle any suspended solids (Maka, 1986). In the presence of $49 \mathrm{mgS}^{2-} / \mathrm{L}, 338 \mathrm{mgS}^{\circ} / \mathrm{L}$ and $191 \mathrm{mgSO}_{4}{ }^{2--S} / \mathrm{L}$, the turbidity 


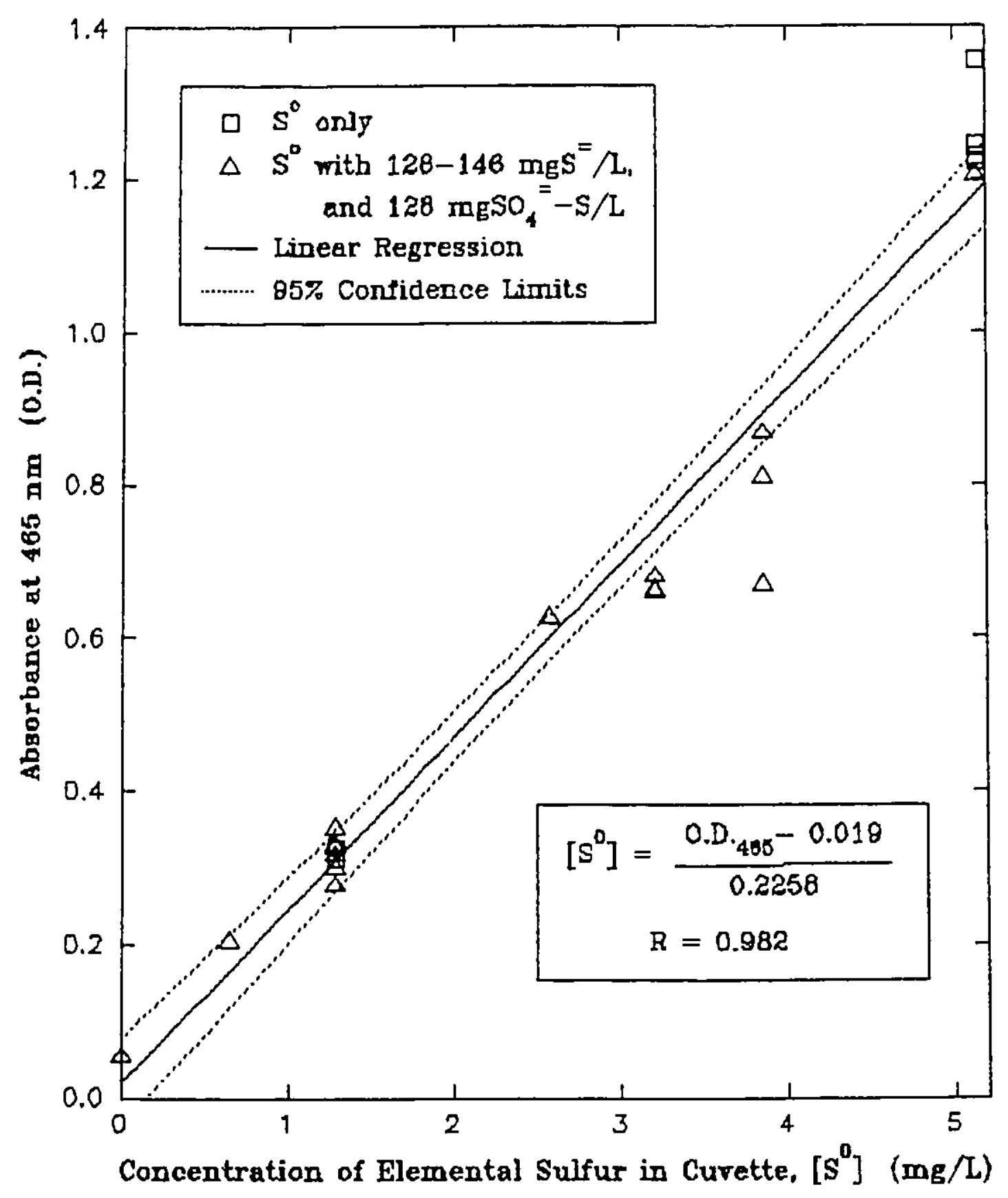

FIGURE A.7 Calibration of Cyanide Method of Elemental Sulfur Analysis With and Without Added Sulfur Compounds 


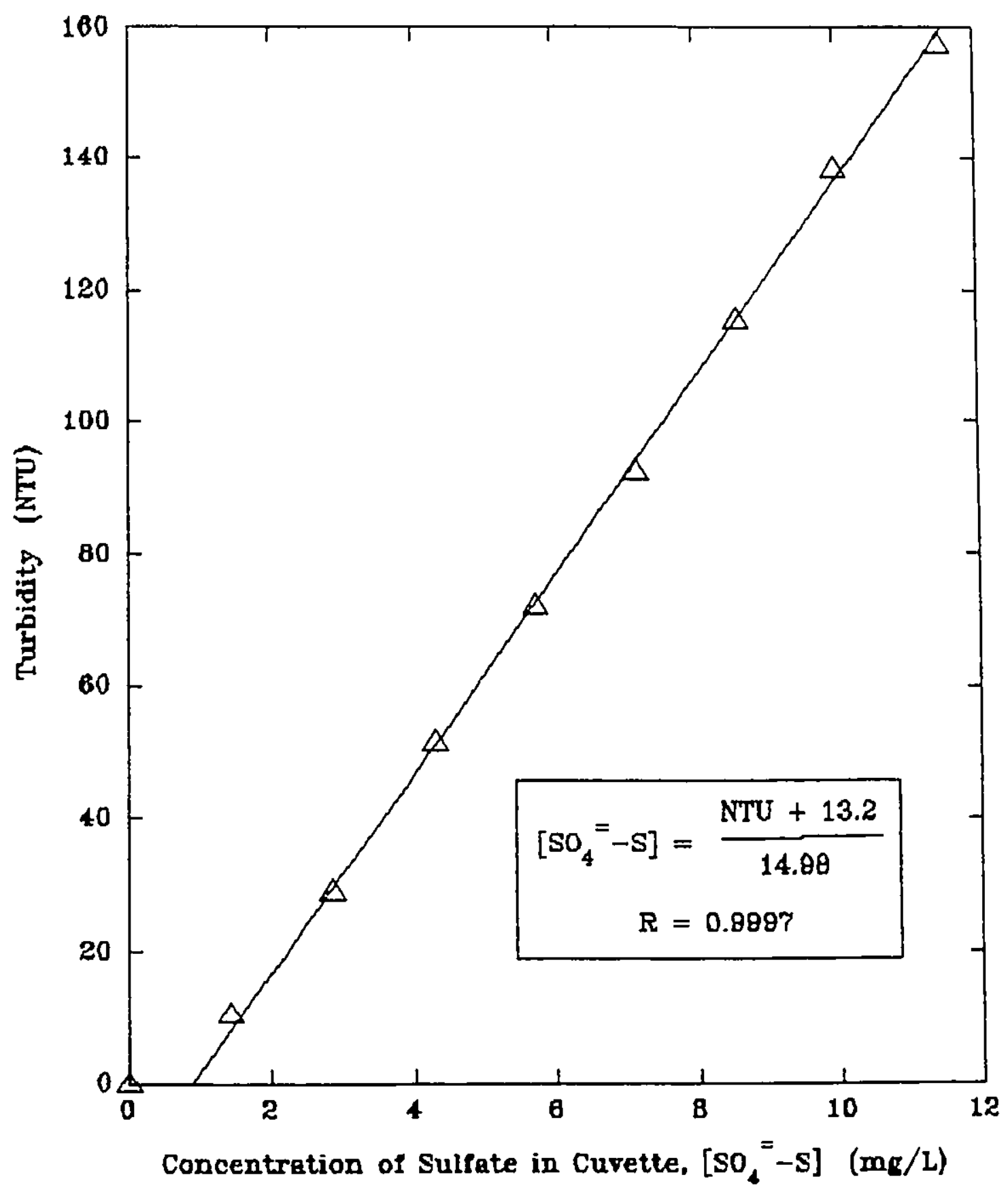

FIGURE A.B Calibration of Turbidimetric Method of Sulfate Analysis Without Added Sulfur Compounds 
Indicated a sulfate concentration of $313 \mathrm{mgSO}^{2--\mathrm{s} / \mathrm{L}}$. In another experiment where $41 \mathrm{mgs}^{2-} / \mathrm{L}, 43 \mathrm{mgS}^{\circ} / \mathrm{L}$ and $43 \mathrm{mgSO}_{4}^{2--S / L}$ were present, the turbidimetric method indicated that $60 \mathrm{mgSO} 4^{2--S / L}$ were present. Further Investigation revealed that in the presence of both sulfide and elemental sulfur, the buffered sample solution turned cloudy before bariun chloride was added.

An investigation was performed using various combinations of sulfide and sulfur to interfere with the sulfate test. Solutions were added to 30 $m$ centrifuge tubes as indicated in Table A.11. After centrifuging for 30 minutes at $3000 \mathrm{rpm}$ a $10.00 \mathrm{~mL}$ sample was plpetted into a $100.00 \mathrm{~mL}$ volumetric flask which was filled to the mark with diHzo. The contents of the volumetric flask was poured into a $250 \mathrm{~mL}$ erlenmeyer flask and a magnetic stir bar was added. $5.0 \mathrm{~mL}$ of buffer A (per $\mathrm{L} d i \mathrm{H}_{2} \mathrm{O}: 30 \mathrm{~g}$ $\mathrm{MgCl}_{2} \cdot 6 \mathrm{H}_{2} \mathrm{O}, 5 \mathrm{~g} \mathrm{Na}\left(\mathrm{CH}_{3} \mathrm{OOO}\right) \cdot 3 \mathrm{H}_{2} \mathrm{O}, 1 \mathrm{~g} \mathrm{KNO}, 20 \mathrm{~mL}$ glacial acetic acid) was added to the erlenmeyer flask. After mild stirring, the turbidimeter cuvette was rinsed and filled. The timer was started and approximately $k$ $\mathrm{mL}$ of $\mathrm{BaCl}_{2}$ crystals was added to the erlenmeyer flask. Stirring was started immediately and lasted for $60 \pm 2$ seconds. When the time read 300 seconds the NTU of the sample without $\mathrm{BaCl}_{2}$ was read. Then the cuvette was rinsed twice and filled with the conten's of the erlenmeyer flask. The turbidity was read at $360 \pm 30$ seconds. The difference between the turbidity without $\mathrm{BaCl}_{2}$ and with $\mathrm{BaCl}_{2}$ was nearly a constant up to a $\mathrm{S}^{\circ}$ concentration of $130 \mathrm{mg} / \mathrm{L}$ in the sample (Table A.11, Figure A.9). Thus, under conditions of limited sulfide and $s^{\circ}$ concentrations, this difference in NTU could be used as an indicator of sulfate concentration.

Bergstein et al.(1983) monitored sulfide and sulfur in a static 


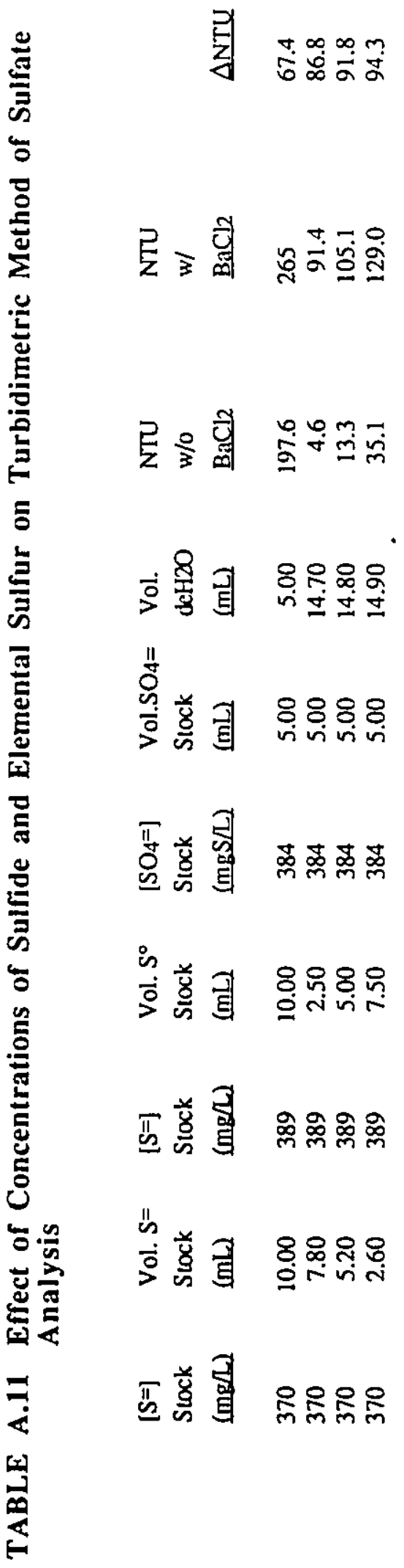




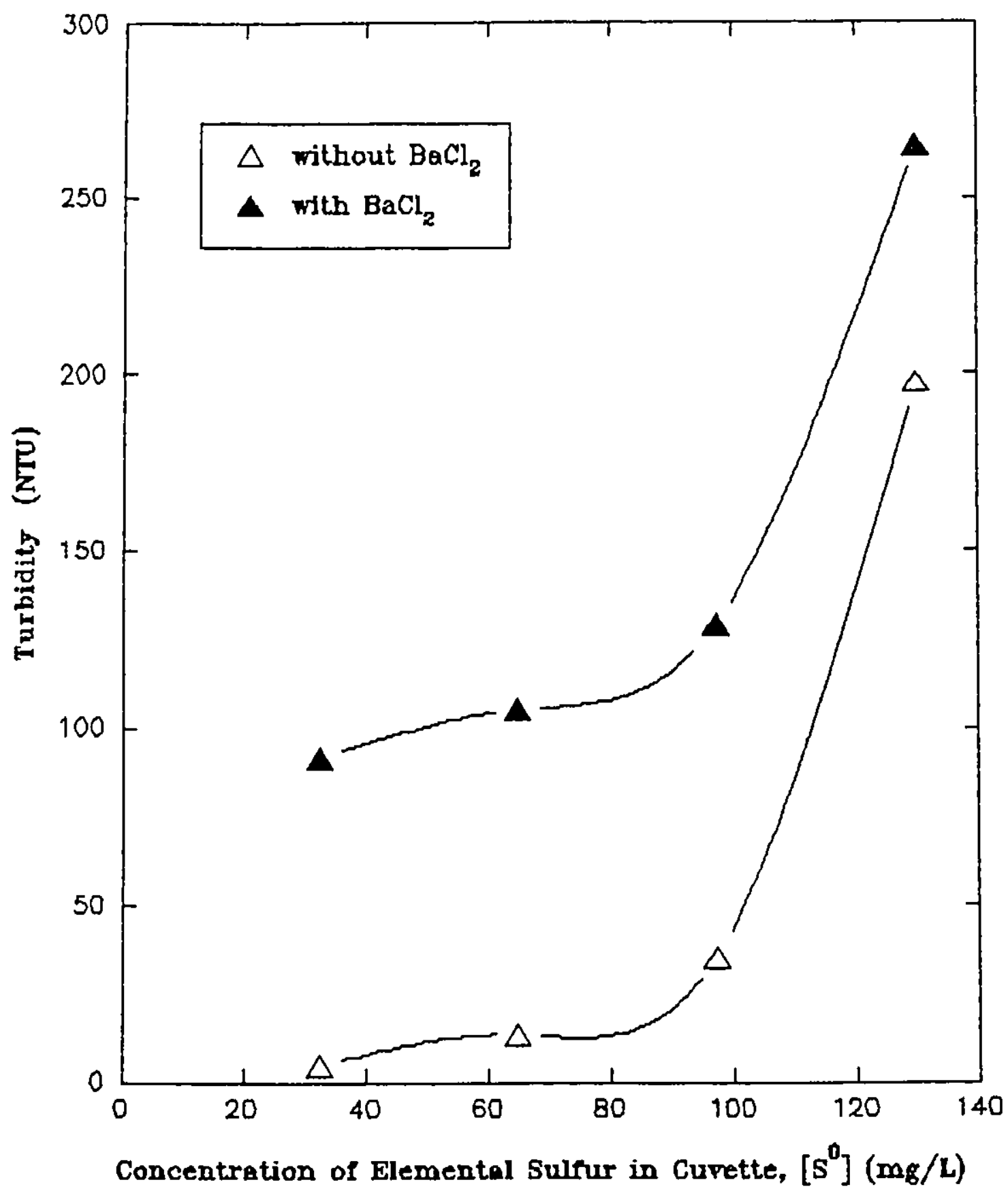

FIGURE A.9 Effect of Concentrations of Sulfide and Elemental Sulfur on Turbidimetric Method of Sulfate Analysis 
culture of Chlorobium phaeobacteriodes and found that from an initial sulfide concentration of $5.05 \mathrm{mM}(162 \mathrm{mg} / \mathrm{L})$, so peaked at $0.9 \mathrm{mM}(29 \mathrm{mg} / \mathrm{L})$ when the sulfide concentration was $2.7 \mathrm{mM}(87 \mathrm{mg} / \mathrm{L})$. These values were used in the test of combined $S^{\circ}$ and sulfate interference in the sulfate calibration.

Sulfate test calibration and interference check were performed as shown in Table A.12. Quantities of sulfide, sulfur and sulfate stock solutions were measured into a $30 \mathrm{~mL}$ centrifuge tube which was covered with parafilm and centrifuged at $3000 \mathrm{rpm}$ for 30 minutes. A pipette was used to transfer $10.00 \mathrm{~mL}$ of the supernatant into a $250 \mathrm{~mL}$ erlenmeyer flask. Then, $90.0 \mathrm{~mL}$ of $\mathrm{dLH}_{2} \mathrm{O}$ we added using a graduated cylinder and a magnetic stir bar was added. A graduated cylinder was used to add $20.0 \mathrm{~mL}$ of buffer $A$, the time clock was started and mild stirring proceeded for about 30 seconds. The turbidimeter curvette was rinsed once with the buffered solution and filled. The turbidity of this solution was measured (NIU, ) $360 \pm 30$ seconds after adding the buffer. To the remaining solution, I $\mathrm{mL}$ of $\mathrm{BaCl}_{2}$ crystals was added at a clock time of 120 seconds and stirred unt1l 180 seconds. This solution (with barlum) was used to fill the cuvette after rinsing it. The turbldity of the solution with barlum was measured at $480 \pm 30$ seconds.

Figure A.10 shows that those samples with sulfide and $S^{\circ}$ in their matrices give turbidities not signiflcantly different than for those samples without $\mathrm{s}^{2-}$ and $\mathrm{S}^{\circ}$. The line of best fit and the 958 confidence limit envelope are shown. The widths of this envelope at the lowest and highest in-range values were measured. The greatest width value was divided by two and used as the uncertainty of the concentration in the 


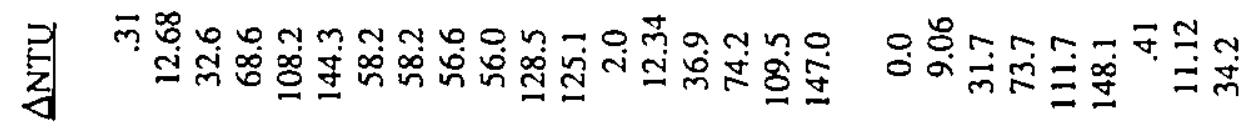

3

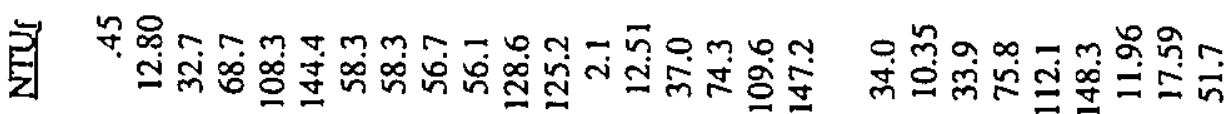

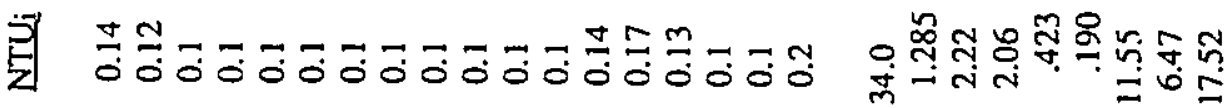

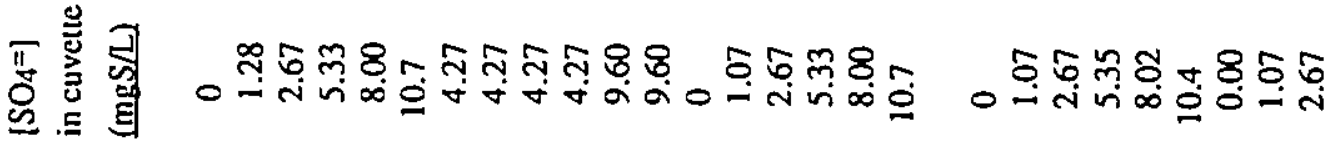

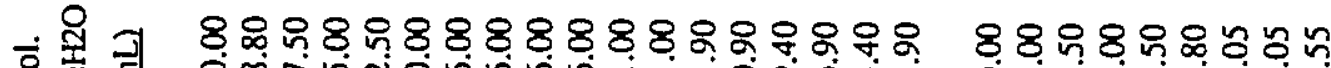

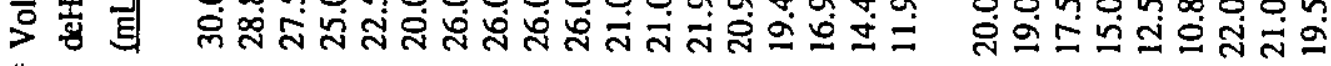

II

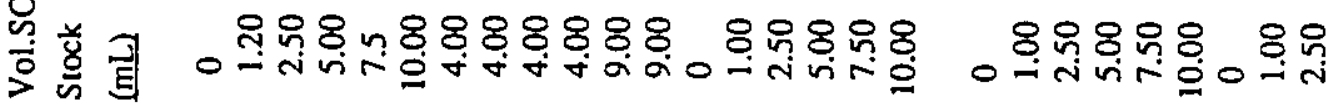

¿

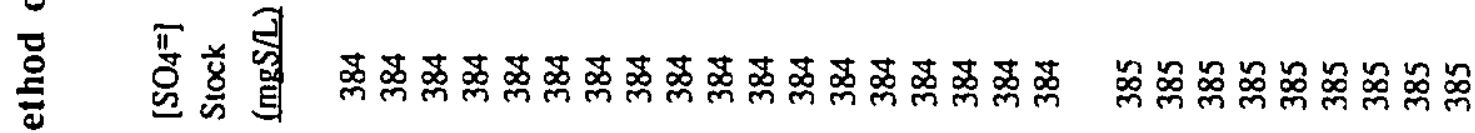

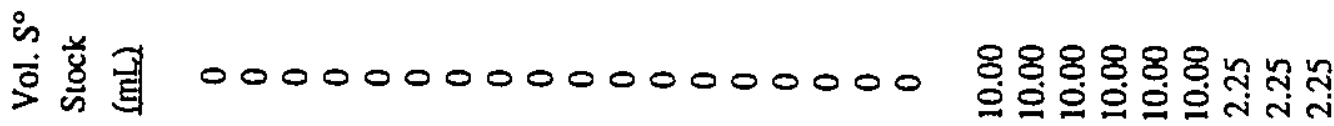

总氪

尾

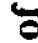

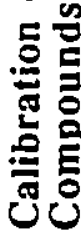

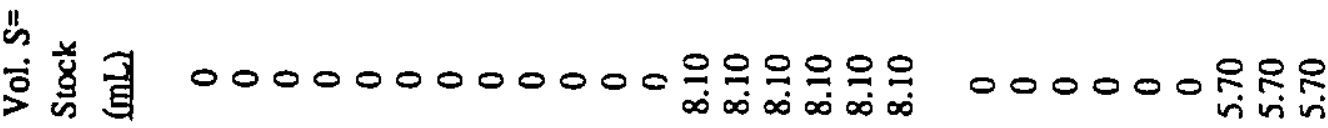

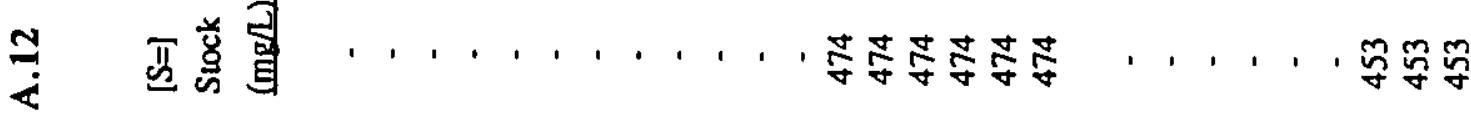

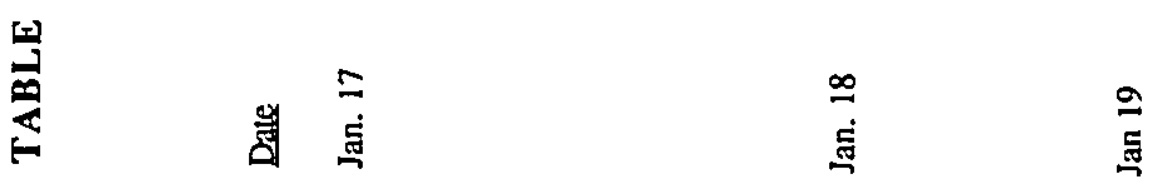


氧

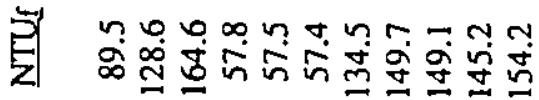

自

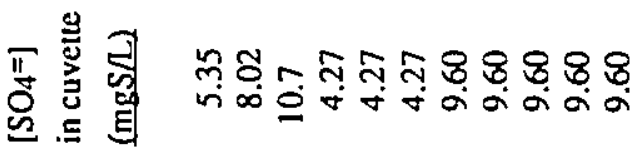

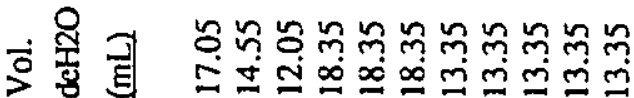

"I

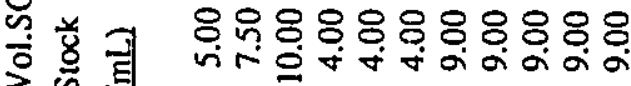

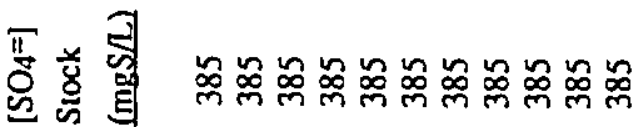

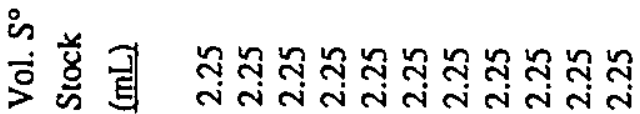

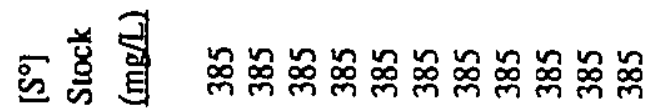

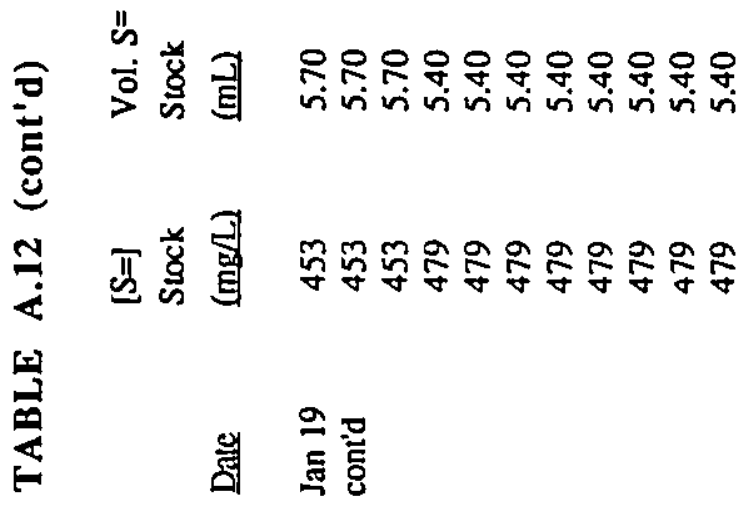




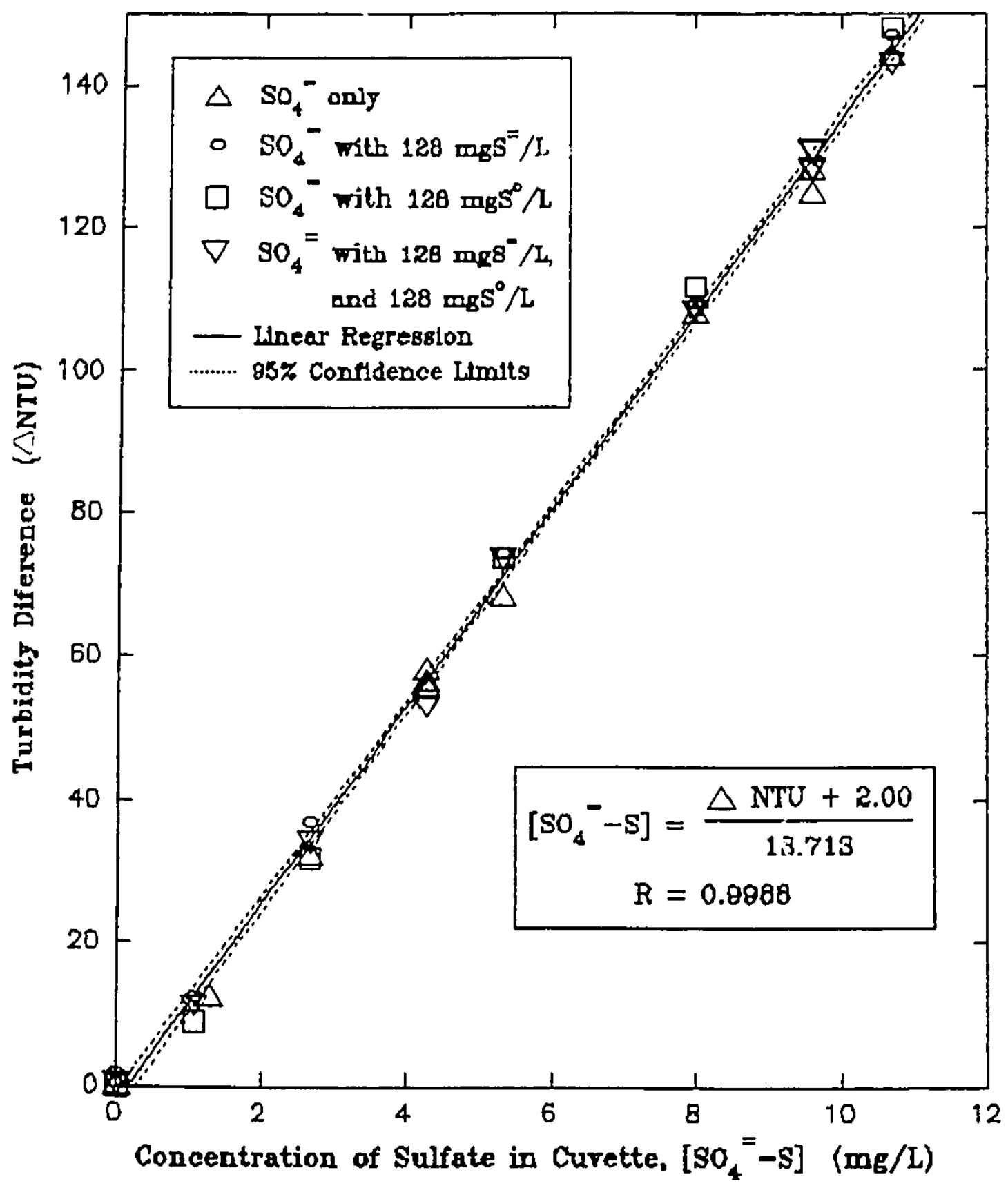

FIGURE A.10 Calibration of Turbidimetric Method of Sulfate Analysis With and Without Added Sulfur Compounds 
cuvette. Figure A.11 shows the region where this modified sulfate method is valid.

\section{A.5 Bacteriochlorophyll}

Kakidas (1982) has shown there is a linear relationship between the number of cells and the mass of bacterlochlorophyll (bchl) for $c$. thiosulfatophilum. She also makes reference to the ratio of $900 \mathrm{mg} / \mathrm{L} \mathrm{dry}$ cell welght to $25 \mathrm{mg} / \mathrm{L} \mathrm{bchl}$. Therefore, the concentration of bchl in a sample of reaction mixture can be used as an indicator of biomass.

The procedure of Maka (1986) was used but the quantitles were doubled (see section 3.1.4). In order to quantify the uncertainty of this measurement, several repetitive measurements of the same reactor solution were made in groups of two (one group of four). The absorbance readings of each group were averaged and the concentration of bchl in the cuvette was calculated using the formula given by Maka (1986) based on that average. The values of absorbance were plotted against the concentration of bchl in the cuvette (Figure A.12). The line of best fit and the $95 \%$ confldence limit envelope are shown. The widths of this envelope at the lowest and highest in-range values were measured. The greatest width value was divided by two and used as the uncertainty of the concentration in the curvette. 


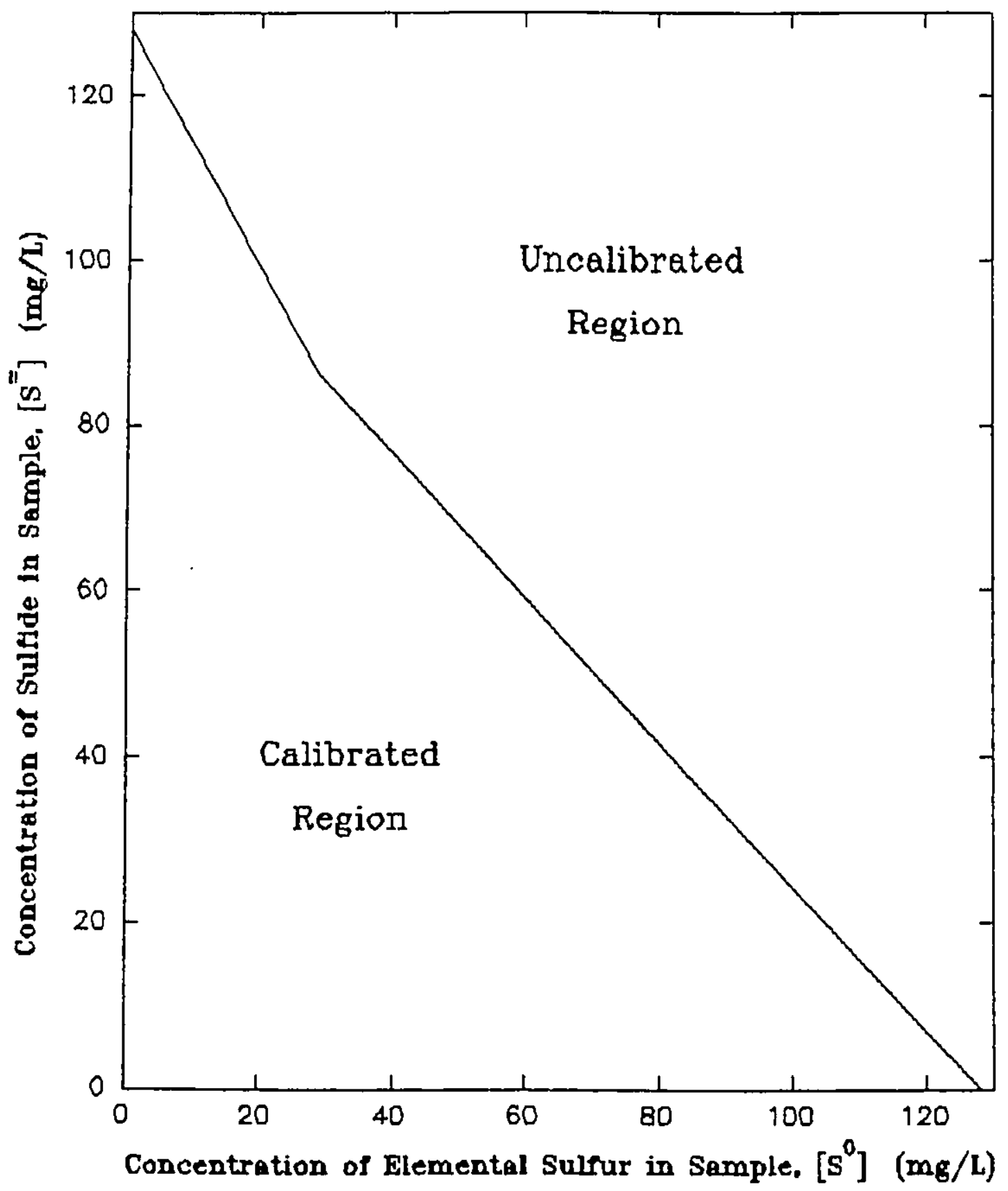

FIGURE A.11 Calibrated Region for Turdidimetric Method of Sulfate Analysis 


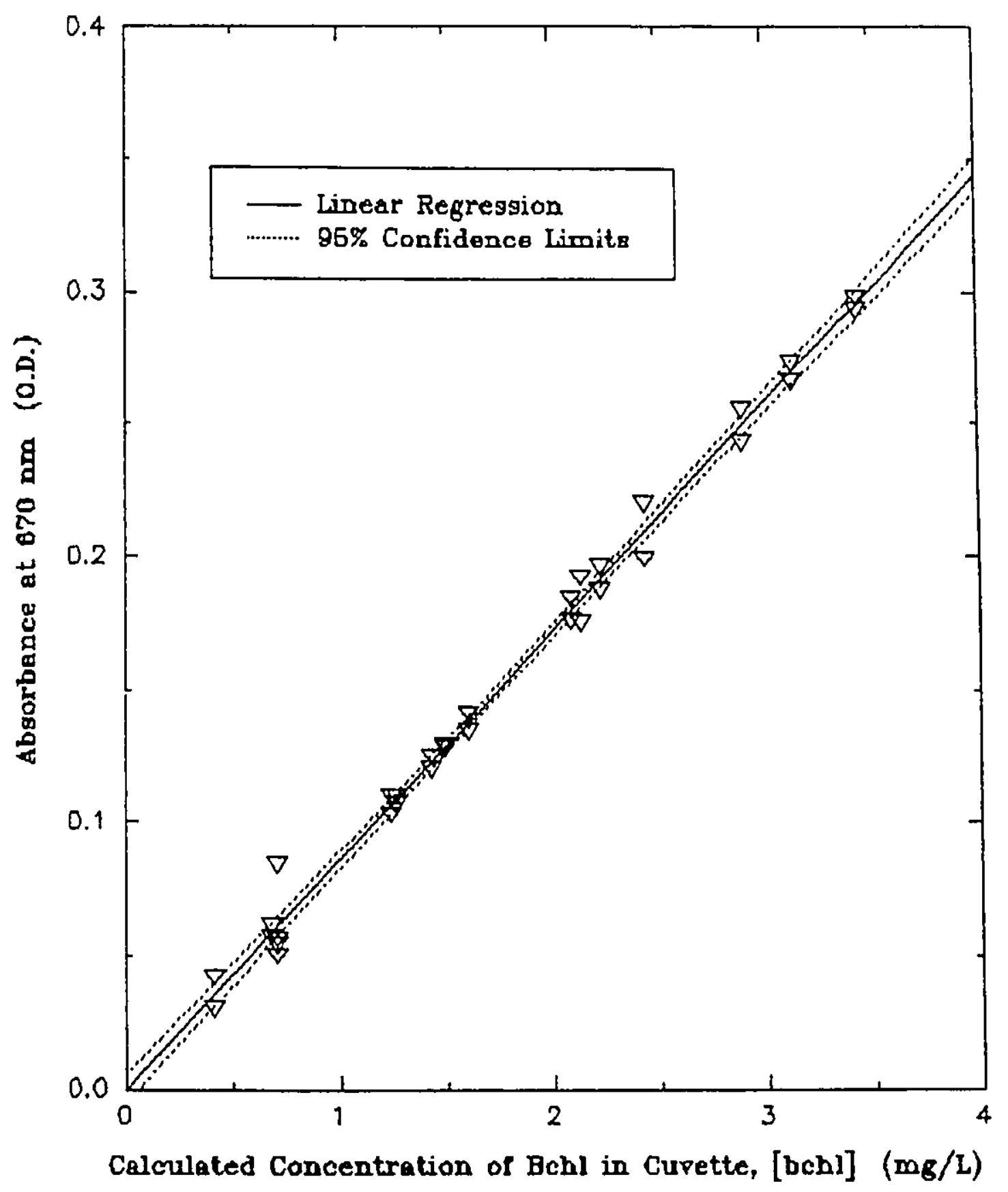

FIGURE A.12 Plot for Calculation of Uncerteinty in Bchl Analysis 


\section{APPENDIX B \\ MzASURETENT OF REACTOR ILLUMINAKCE}

\section{B.1 Materials and Methods}

The top of the $15 \mathrm{~L}$ reactor was removed and the glass reactor was immersed in the fermentor drive assembly water bath as in an experimental run (Section 3.2.2). Weights were added to the bottom of the flask to keep it from floating while the waterbath was filled. The sensor of an International Light 1L 1700 Research Radiometer was positioned inside the reactor and normal to the light source at twelve locations as jilown in Fiqure B.1, The light intentsity was measured with SED038/F/W, SED038/Y/W and SED038/TFDR/W filter combinations.

The resultant values for each sensor combination were integrated over the frontal area of the reactor. The locations of the sensor during measurements were consldered as nodes. The reactor front projection area was divided into 20 rectangles having nodes at 1 to 4 corners. The average of the light measurements at the four nodes was multiplied by the area of the rectangle. Where a light measurement was not avallable, a node value was linearly extrapolated from the previous two nodes in-line. When extrapolated node values were negative, zero was used as the node value. The sum of the average values $x$ rectangle arei.s was divided by the total frontal area of the reactor. 


\section{B.2 Results}

The following table sumnarizes the measurements of light

11luminance:

Filter

SED 038/Y/W

SED 038/F/W

SED 038/TFRD/W
Range of Light

Measured

Visible

$400-700 \mathrm{~nm}$

Infra-Red
Incident

Radiation

$7.09 \mathrm{~W}$

$2.78 \mathrm{~W}$
Reactor I Lluminance 2400 lux

$1.2 \times 10^{-2} \mathrm{~W} / \mathrm{cm}^{2}$

$4.7 \times 10^{-3} \mathrm{~W} / \mathrm{cm}^{2}$ 


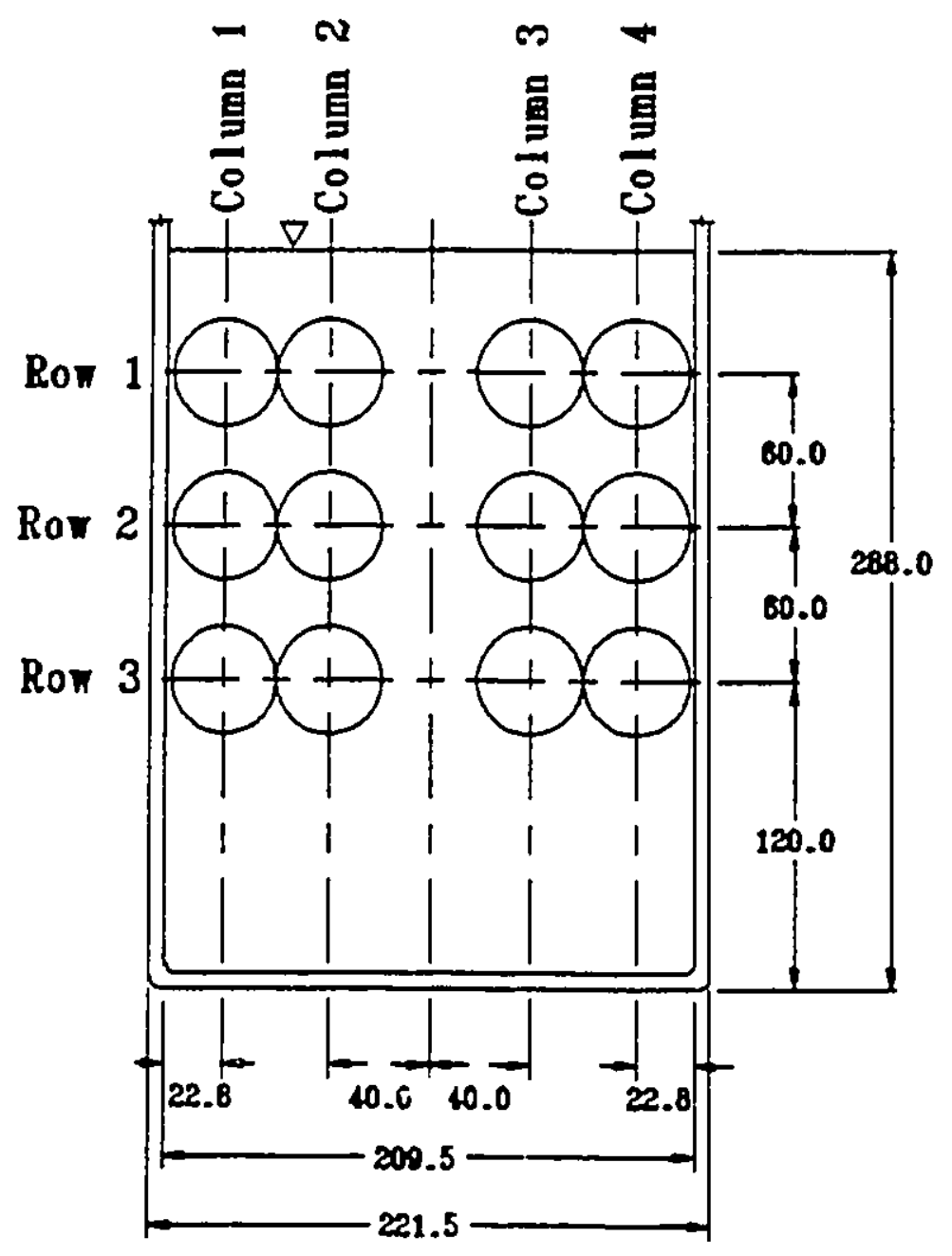

FIGURE B.1 Sensor Locations for Heasuring React or Ill uminance

sll dineneions in $\mathrm{nn}$ 


\section{APPBNDIX C \\ CALCULATION OF THE AMOUNT OF AVAILABLE CARBON DIOXIDB}

\section{1 Carbon Dioxide Inputs}

1. $3.6 \mathrm{~L}$ of $\mathrm{diH}_{2} \mathrm{O}$ saturated with $\mathrm{CO}_{2}$

- solubility of $\mathrm{CO}_{2}$ In water at $25^{\circ} \mathrm{C}=0.145 \mathrm{~g} / 100 \mathrm{~mL}$ (CRC, 1980)

$3.6 \mathrm{~L} \times 1.45 \mathrm{gCO}_{2} / \mathrm{L}=5.2 \mathrm{gCO}_{2}$

2. $18 \mathrm{~g}$ of $\mathrm{NaHCO}_{3}$

$18 \mathrm{~g} \mathrm{NaHCO}, \times \frac{44.01 \mathrm{gCO}_{2}}{84.0 \mathrm{gNaHCO}_{3}}=9.4 \mathrm{gCO}_{2}$

3. Total

$5.2 \mathrm{gCO}_{2}+9.43 \mathrm{gCO}_{2}=14.6 \mathrm{gCO}_{2}$

\section{2 Sulfide That Can be Utilized}

1. Refer to equation [2.2]

$14.6 \mathrm{gCO}_{2} \times \frac{2 \text { moles } \mathrm{H}_{2} \mathrm{~S}}{\text { mole } \mathrm{CO}_{2}} \times \frac{32.06 \mathrm{gS}^{2}-/ \text { mole } \mathrm{H}_{2} \mathrm{~S}}{44.01 \mathrm{gCO}_{2} / \mathrm{mole}_{2}}$

$=21.3 \mathrm{gS}^{2-}$

2. Equivalent Concentration of $\mathrm{S}^{2-}$

$$
\frac{21.3 \mathrm{gs}^{2}-}{9.5 \mathrm{~L}}=2240 \mathrm{mgs}^{2}-/ \mathrm{L}
$$

3. Therefore there is enough $\mathrm{CO}_{2}$ to allow for an initial concentration of $2240 \mathrm{mgs}^{2-/ L}$ in the reactor, or a series of infections where the sum of sulfide concentrations is 2240 mgs $2-/ L$. This is a conservative estimate since neither the $\mathrm{CO}_{2}$ retained in the headspace nor that dissolved in the mineral salts solution upon purging the reactor were taken into account. 
VITA AUCTORIS

1961 Born in Windsor, Ontario, Canada, on June 14.

1978 Awarded Ontario Secondary School Graduation Diploma from Centennial Secondary School, Windsor, Ontarlo.

1979 Awarded Ontario Secondary School Honour Graduation Diploma from Centennial Secondary School, Windsor, Ontario.

1979 Awarded University of Western Ontario Entrance Scholarship.

1981 Aharded NSERC University Summex Research Scholarship.

1982 Completed the Degree of Bachelor of Science in Chemistry at the University of Western Ontario, London, Ontario, Canada.

1984 Awarded NSERC Industrial Sumer Research Scholarship.

1985 Completed the Degree of Bachelor of Engineering Sclence in Mechanical Englneering at the University of Western Ontario, London, Ontario, Canada.

1985 Began employment as Jr. Mechanical Engineer at Chorley \&

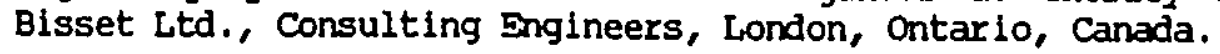

1987 Began employment as Mechanical Engineer at Wilson, Dario \& Assoclates, Consulting Engineers, Windsor, Ontario, Canada.

1989 Awarded Ontario Graduate Scholarship.

1990 Awarded NSERC Postgraduate Scholarship. 